Andrews University

Digital Commons @ Andrews University

Professional Dissertations DMin

Graduate Research

2002

\title{
La Iglesia Adventista Frente a la Disidencia en Colombia
}

Jose Evelio Garcia

Andrews University

Follow this and additional works at: https://digitalcommons.andrews.edu/dmin

Part of the Practical Theology Commons

\section{Recommended Citation}

Garcia, Jose Evelio, "La Iglesia Adventista Frente a la Disidencia en Colombia" (2002). Professional Dissertations DMin. 538.

https://dx.doi.org/10.32597/dmin/538

https://digitalcommons.andrews.edu/dmin/538

This Project Report is brought to you for free and open access by the Graduate Research at Digital Commons @ Andrews University. It has been accepted for inclusion in Professional Dissertations DMin by an authorized administrator of Digital Commons @ Andrews University. For more information, please contact repository@andrews.edu. 


\begin{abstract}
THE ADVENTIST CHURCH FACING

DISSIDENCE IN COLOMBIA
\end{abstract}

by

José Evelio García

Adviser: Werner K. Vyhmeister 


\title{
ABSTRACT OF GRADUATE STUDENT I 690 - I
}

Dissertation

\author{
Andrews University \\ Seventh-day Adventist Theological \\ Montemorelos Extensi
}

Title: THE ADVENTIST CHURCH FACING DISSIDE_........ MBIA

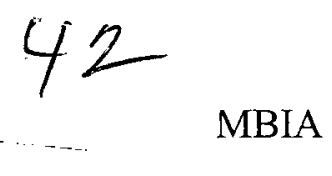

Name of researcher: José Evelio García

Name and degree of adviser: Werner K. Vyhmeister, Ph.D.

Date completed: June 2002

The Seventh-day Adventist Church in Colombia at this time is facing dissidence from the group Koinonia. This research was carried out in order to produce material to help pastors, ministerial students, and laypeople to understand and face this dissident movement.

The Bible and the writings of Ellen G. White provide the principles on which the Seventh-day Adventist Church has been established. These principles have been applied in order to face the problem caused by the group Koinonia in Colombia. 
In order to understand what Koinonia teaches and how it operates, a number of interviews were conducted with former Koinonia supporters, with Seventh-day Adventist Church administrators in Colombia, with district pastors, with laypeople who have been influenced by Koinonia, and with ministerial students who have been in contact with those who spread the ideas of Koinonia.

After a study of the biblical doctrine of the church, Koinonia activities and beliefs were analyzed. The three main areas of contention are that Koinonia maintains that the Seventh-day Adventist Church is in apostasy, that its organization makes it Babylon, and that each person is free to choose where he or she will pay tithe. Each of these ideas is refuted.

God established the church through Christ. The church is not perfect; it is not the kingdom of God. However, this does not mean that the church that God established is in apostasy. The believers in the church are instruments in God's hands to promote the salvation of human beings.

In view of the accusations of Koinonia and its persistent hostility, the Seventh-day Adventist Church cannot retain as members those who side with Koinonia in opposition to the church. 
SÍNTESIS

LA IGLESIA ADVENTISTA FRENTE A LA

DISIDENCIA EN COLOMBIA

por

José Evelio García

Asesor: Werner K. Vyhmeister 


\title{
SÍNTESIS DE TESIS DOCTORAL
}

\author{
Andrews University \\ Seventh-day Adventist Theological Seminary \\ Extensión Montemorelos, México
}

Título: LA IGLESIA ADVENTISTA FRENTE A LA DISIDENCIA EN COLOMBIA

Nombre del Investigador: José Evelio García

Nombre y grado del asesor de tesis: Werner K. Vyhmeister, Doctor en Filosofia

Fecha de conclusión: Agosto de 2002

La Iglesia Adventista del Séptimo Día en Colombia enfrenta por algunos años al movimiento Koinonía. Este trabajo de investigación fue llevado a cabo para producir un material que ayude a los pastores, a estudiantes aspirantes al ministerio y a laicos a entender y enfrentar a este movimiento disidente.

La Biblia y los escritos de Elena de White presentan los principios generales en que se basa la Iglesia Adventista del Séptimo Día. Estos principios han sido aplicados al encarar el problema creado por el grupo Koinonia en el territorio colombiano.

Para poder establecer las ideas y las posiciones tomadas por Koinonia, se realizaron varias entrevistas con personas que han militado en el movimiento, con administradores de las organizaciones de la Iglesia Adventista en Colombia, con pastores 
distritales, con laicos que han sido afectados por las ideas disidentes y con estudiantes de teología que han estado en contacto personal con los que diseminan esas ideas.

El problema generado por Koinonía incluye su crítica destructiva de la iglesia y de su liderazgo, a quienes declara en apostasía; su espíritu de independencia de la estructura y la organización; y sus esfuerzos por captar los diezmos y otros dineros de miembros que no están satisfechos dentro de la iglesia.

El origen de la iglesia es Dios, quien la llama y la convoca en Cristo. La iglesia no es perfecta, no es el reino de Dios. Defe diferenciarse entre la apostasia en la iglesia y la apostasía de la iglesia. La comunidad de creyentes, es un instrumento en las manos del Creador para promover el reino en pro de la salvación de los hombres.

La iglesia, frente a las acusaciones de Koinonia y a su persistente hostilidad, considera que quienes respaldan a este grupo no deben ser retenidos como miembros de la Iglesia Adventista a menos que cambien de actitud. 
Andrews University

Seventh-day Adventist Theological Seminary

Extensión Montemorelos, México

\title{
LA IGLESIA ADVENTISTA FRENTE A LA \\ DISIDENCIA EN COLOMBIA
}

\author{
Tesis \\ presentada en cumplimiento parcial \\ de los requisitos para el grado de \\ Doctor en Ministerio
}

por

José Evelio García

Agosto 2002 



\section{LA IGLESIA ADVENTISTA FRENTE A LA DISIDENCIA EN COLOMBIA}

Tesis

presentada en cumplimiento parcial

de los requisitos para el grado de

Doctor en Ministerio

por

José Evelio García

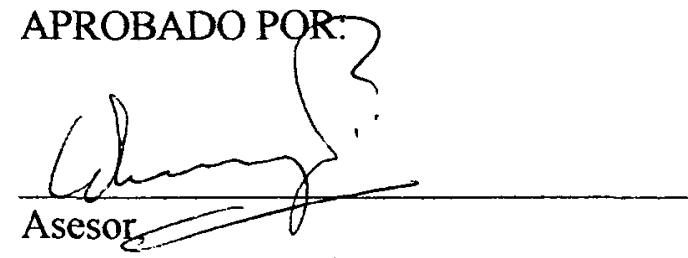

Werner K. Vyhmeister

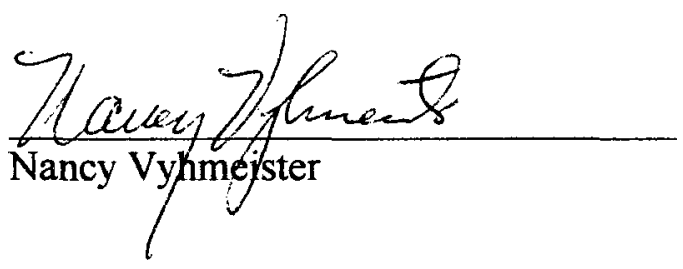

\section{Ricado Inotin}

Coordinador, Extensión Montemorelos, Ricardo Norton

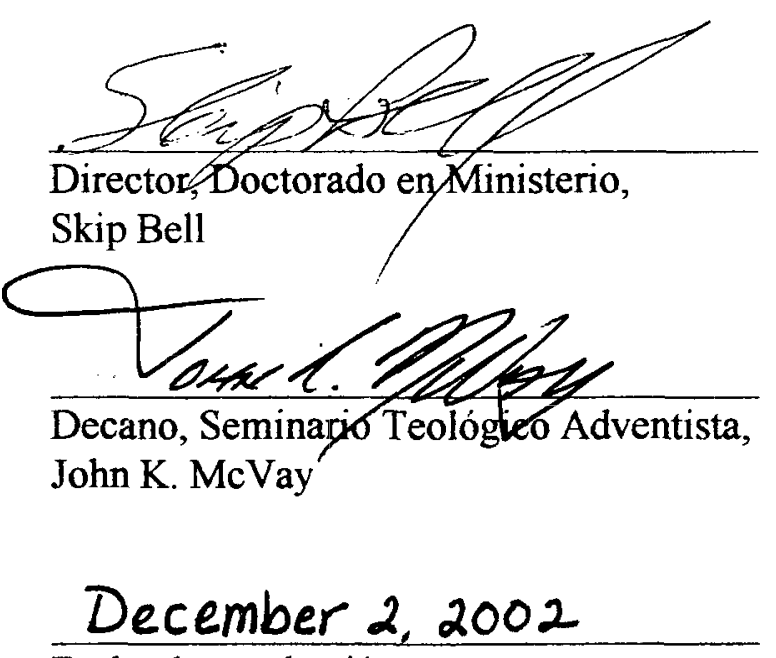

Fecha de aprobación 


\author{
A Dios primeramente. \\ A mi esposa Consuelo y \\ a mis hijos Juan David, Pablo Andrés y \\ Claudia Lorena por su apoyo. \\ A la Unión Colombiana \\ y a la Corporación Universitaria \\ Adventista por su \\ ayuda financiera y motivación.
}




\section{ÍNDICE DE CONTENIDO}

\section{Capítulo}

I. INTRODUCCIÓN $\ldots \ldots \ldots \ldots \ldots \ldots \ldots \ldots \ldots$

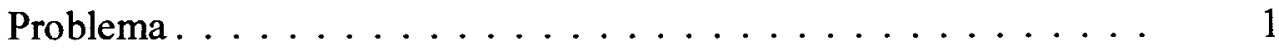

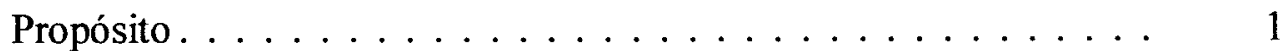

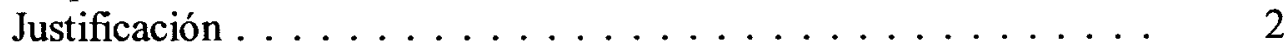

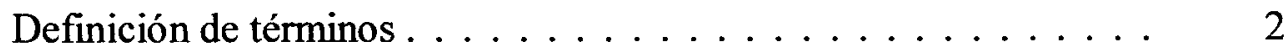

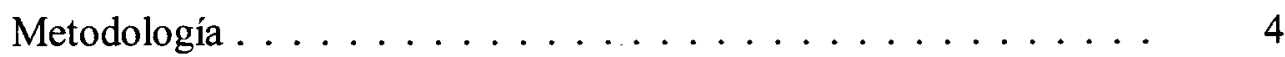

Delimitaciones. .................. 4

Sinopsis del estudio. ..................... 5

II. HISTORIA DEL MOVIMIENTO DISIDENTE KOINONÍA

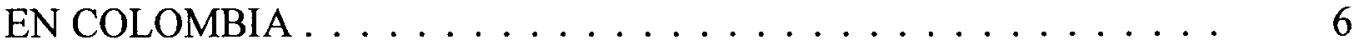

Una síntesis de la historia de la Iglesia Adventista en

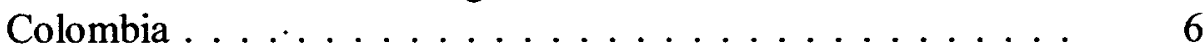

Historia del movimiento Koinonia en Colombia . . . . . . . . . 7

Creencias. ....................... 11

La iglesia organizada apostató en $1888 \ldots \ldots \ldots \ldots 11$

La efectividad de la obra está en la acción laica . . . . . . . . . 12

El diezmo puede ser usado a criterio del

Miembro de iglesia. . . . . . . . . . . . . . . . . 12

La organización es un obstáculo para hacer la obra de la iglesia . . . . . . . . . . . . . . . . . . . . . . 13

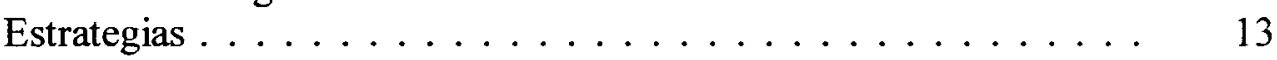

Distribución de literatura . . . . . . . . . . . . . . . . . 13

Conferencias y seminarios. . . . . . . . . . . . . . . 14

Permanecer en la iglesia como miembros . . . . . . . . . . 15

Contactos con personas que manejan recursos económicos. . . . 15

Educación para laicos . . . . . . . . . . . . . 16

III. LA IGLESIA EN EL NUEVO TESTAMENTO . . . . . . . . . . . . . . 18

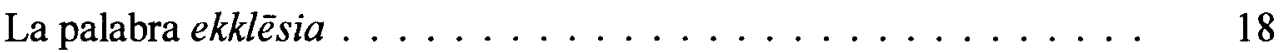

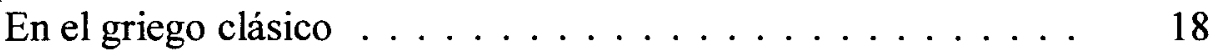

En el Nuevo Testamento. . . . . . . . . . . . . 20 
La iglesia que describe el Nuevo Testamento . . . . . . . . . . . . . . . . 21

El reino de Dios en las enseñanzas de Jesús . . . . . . . . . . . . . 22

No es un reino temporal . . . . . . . . . . . . . . . . . 24

Es el reino de la gracia. . . . . . . . . . . . . . . . . 25

La iglesia en el pensamiento de Jesús . . . . . . . . . . . . 27

Jesús promete edificar su iglesia . . . . . . . . . . . . . . 27

Jesús anuncia la transferencia del reino . . . . . . . . . . . 30

La iglesia en el pensamiento paulino ..................... 32

Iglesia, congregación y comunidad. . . . . . . . . . . 22

Cristo en las epístolas paulinas . . . . . . . . . . . 34

La iglesia en el Apocalipsis. . . . . . . . . . . . . . . 37

Cristo en el mensaje apocalíptico. . . . . . . . . . . 37

Cristo continúa guiando su iglesia . . . . . . . . . 38

Cristo y su iglesia. . . . . . . . . . . . . . 39

Conclusión. . . . . . . . . . . . . . . . . . 42

IV. LA IGLESIA EN LOS ESCRITOS DE ELENA DE WHITE . . . . . . . 43

Vida y obra de Elena G. de White. . . . . . . . . . . . . . 43

Elena de White y la iglesia. . . . . . . . . . . . . . . . . . 45

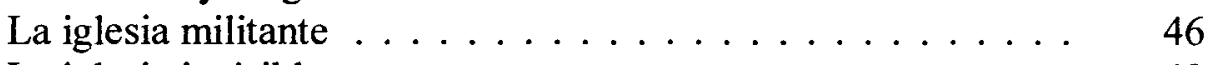

La iglesia invisible. . . . . . . . . . . . . . . . . . . 49

La iglesia y el remanente . . . . . . . . . . . . . . . . 52

El remanente a partir del siglo XVI .......... 53

El remanente del tiempo del fin. . . . . . . . . . . . . . . 55

El remanente y la crisis final ........................ 57

Conclusión....................... 58

V. ASPECTOS PECULIARES DE LA ECLESIOLOGÍA DEL

MOVIMIENTO KOINONIA . . . . . . . . . . . . . . .

La Iglesia Adventista en apostasía . . . . . . . . . . . . . . . . 59

Definiciones de apostasía . . . . . . . . . . . . . . . 60

Según Koinonía. . . . . . . . . . . . . . 60

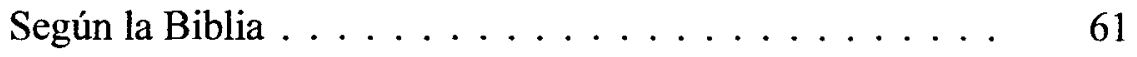

Según Elena de White .............................. 62

Apostasía en Minneápolis en 1888 . . . . . . . . . . . . . 63

Apostasía e iglesia verdadera . . . . . . . . . . . . . . . . 65

Apostasía alfa y omega ........................... 66

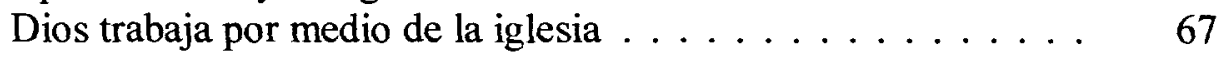

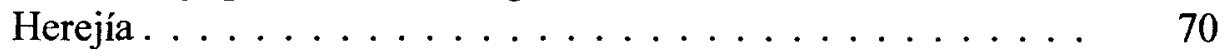

Unidad de la iglesia . . . . . . . . . . . . . . . . . . 73

Santos y pecadores en la iglesia . . . . . . . . . . 75 


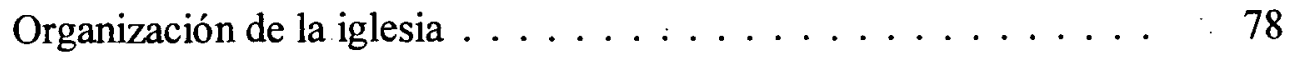

El Espíritu Santo legitima la organización . . . . . . . . . 79

Sacerdocio de todos los creyentes . . . . . . . . . . . 80

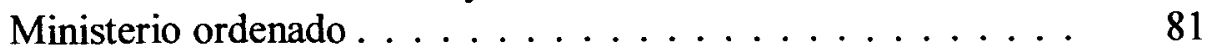

El uso del diezmo . . . . . . . . . . . . . . . . . . . . . 84

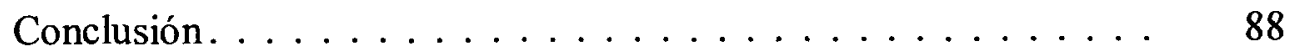

VI. RESUMEN, CONCLUSIONES Y RECOMENDACIONES . . . . . . 89

Resumen . . . . . . . . . . . . . . . . . . . 89

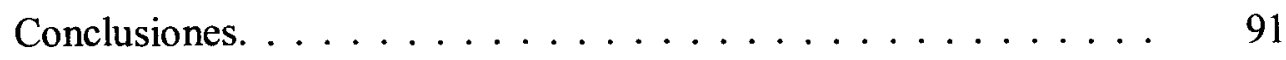

Recomendaciones. . . . . . . . . . . . . . . . 92

APÉNDICE: CITAS DE LOS ESCRITOS DE ELENA G. DE WHITE. . . . . . 94

BIBLIOGRAFÍA $\ldots \ldots \ldots \ldots \ldots \ldots \ldots \ldots \ldots \ldots \ldots$

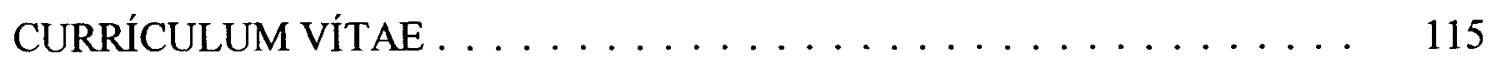




\section{CAPÍTULO I}

\section{INTRODUCCIÓN}

Este trabajo de investigación se realiza en respuesta a la diseminación de ideas eclesiológicas particulares del movimiento Koinonia en las iglesias adventistas en Colombia. Tales ideas comenzaron a ser diseminadas por Norberto Restrepo en torno a 1977.

\section{Problema}

El movimiento Koinonia cuenta con simpatizantes en unas cuantas congregaciones adventistas de Colombia, atraídos por el énfasis en un ministerio independiente de sostén propio; la independencia de cada creyente, que no debe someterse a ninguna organización eclesiástica; el derecho de cada persona a disponer del diezmo como su conciencia se lo dicte; la vida en el campo; y la reforma pro salud. Se añade a esto la idea que la Iglesia Adventista del Séptimo Día apostató en 1888.

\section{Propósito}

El propósito de esta tesis es examinar ciertos elementos particulares de la eclesiología del grupo Koinonía y elaborar un material que ayude a entender y enfrentar a este grupo. 


\section{Justificación}

No es posible ignorar la influencia negativa del grupo Koinonía sobre algunos miembros de iglesia. Los nuevos conversos también necesitan consolidar su confianza en la iglesia. Surge la necesidad de un estudio que disipe las dudas que ocasionan las enseñanzas de Koinonía y que minan la confianza en la iglesia y su liderazgo.

\section{Definición de términos}

Koinonia. Es el nombre con el cual se identifica el movimiento disidente en Colombia.' Esta palabra griega, en las versiones castellanas de la Biblia, se traduce por comunicación, comunión, comunidad, participación (Hch. 2:42; 2 Co. 6:14). ${ }^{2}$ Según el Comentario biblico adventista queda claro, dentro del contexto de Hechos 2 , que la palabra se refiere a la hermandad que existió entre los apóstoles y los nuevos conversos ${ }^{3}$

Eclesiología. Es el estudio de la doctrina de la iglesia. En el Diccionario enciclopédico ilustrado se define como el "tratado de la iglesia, o sea obra o discurso que trata de los origenes, naturaleza y derechos de la iglesia". 4

'[Elena G. de White], Salid de las ciudades (Barquisimeto Fundación Las Delicias s.f.).

${ }^{2}$ Diccionario bíblico ilustrado (DBI), ed. 1983, ver "koinonia".

3"Koinonia" [Hch. 2:42], Comentario biblico adventista (CBA), 7 vols. ed. F. D. Nichol, trad V. E. Ampuero Matta (Boise: Publicaciones Interamericanas, 19781990), 6:152.

${ }^{4}$ Diccionario enciclopédico ilustrado, ed. 1995, ver "eclesiología". 
Disidencia. Es el término con el cual se denomina a quienes se separan "de la común doctrina, creencia o conducta".

Apostasía. Según el Diccionario biblico ilustrado significa "volverse atrás, regresar, escapar hacia atrás. Los autores cristianos entienden por apostasía el abandono de la fe".2

Laico. Yves M.-J. Congar observa que "en el lenguaje judio y después cristiano, designaba propiamente el pueblo consagrado por oposición a los pueblos profanos: matiz que estuvo presente en los espiritus, al menos cuando se expresaban en griego, durante los cuatro primeros siglos e incluso más tarde". ${ }^{3}$ En este trabajo se refiere al miembro de iglesia que no es un empleado de la denominación.

Verdad presente. Tal como lo explica Elena de White, es el mensaje o la verdad que se adapta o se aplica a las condiciones de la generación del momento. ${ }^{4}$

Escatología. Esta palabra viene del término griego esjatos, cuyo significado es: último, extremo; el más remoto, alejado, lejano. ${ }^{5}$

'Diccionario de la lengua española, Real Academia, ed. 1970, ver "disidencia".

${ }^{2} D B I$, ver "apostasía".

${ }^{3}$ Yves M.-J. Congar, Jalones para una teología del laicado, trad. Sebastián Fuster, $3^{\mathrm{a}}$ ed. (Barcelona: Estela, 1965), 23.

${ }^{4}$ Elena G. de White, Joyas de los testimonios, 3 vols. (Mountain View, California: Publicaciones Interamericanas, 1953), 1:284.

${ }^{5} J$ osé M. Pabón de Urbina. Diccionario manual griego-español, ed. 1994, ver "esjatos". 
Escatología, en términos generales, según. Franz-Josef Nocke es el estudio de los acontecimientos finales. ${ }^{\prime}$

Militante. Aplicado a la iglesia, significa la forma como los fieles combaten (espiritualmente) en la tierra. ${ }^{2}$

\section{Metodología}

La investigación gira alrededor de las ideas controversiales enseñadas por el grupo Koinonía que tienen su base en algunos elementos eclesiológicos particulares. Además de la necesaria investigación bíblica se empleó también la entrevista personal.

\section{Delimitaciones}

Esta investigación no pretende ser un estudio exhaustivo del tema. Es, más bien, un breve planteamiento de los problemas vinculados con el grupo koinonía. El estudio se limita a aspectos controvertidos de su eclesiología.

En este trabajo no se incluye un estudio de la reforma pro salud ni de la salida de las ciudades para el campo, temas que interesan mucho a koinonía Requerirían la realización de otro estudio.

\footnotetext{
'Franz Josef Nocke, Escatologia (Barcelona: Herder, 1984), 11.

${ }^{2}$ Nuevo pequeño Larousse ilustrado, ed. 1963, ver "militante".
} 
5

\section{Sinopsis del estudio}

Este trabajo de investigación está distribuido en seis capítulos: el capítulo 1 comprende la introducción al estudio. El capítulo 2 expone brevemente la historia del movimiento Koinonía en Colombia. El capítulo 3 estudia la iglesia en la Biblia. El capítulo 4 presenta la iglesia en los escritos de Elena de White. El capítulo 5 realiza una evaluación de algunos aspectos de la eclesiología particular del movimiento Koinonía. Y finalmente, el capítulo 6 se ocupa del resumen, conclusiones y recomendaciones. 


\section{CAPÍTULO II}

\section{HISTORIA DEL MOVIMIENTO KOINONIA EN COLOMBIA}

Este capitulo comprende la historia, y una breve presentación de algunos aspectos eclesiológicos particulares y estrategias del movimiento Koinonía en Colombia. Como marco de fondo, se presenta primero una apretada síntesis de la historia de la Iglesia Adventista en Colombia.

\section{Una síntesis de la historia de la Iglesia Adventista en Colombia}

La Iglesia Adventista del Séptimo Día surgió en Norteamérica a mediados del siglo XIX. En 1874 la iglesia envió a Europa su primer misionero. Hoy hay más de doce millones de adventistas en 204 paises y áreas de la tierra. ${ }^{1}$

Una figura destacada en la historia de la Iglesia Adventista desde sus comienzos fue Elena G. de White (1827-1915). Los adventistas creen que en su ministerio de más de 60 años se manifestó el auténtico don profético. Sus numerosos escritos ejercen considerable influencia. ${ }^{2}$ Con cierta frecuencia, son también usados por movimientos disidentes.

'General Conference of Seventh-day Adventists, Annual Statistical Report (Silver Spring, MD: General Conference of SDA, 2000), 67, 70.

${ }^{2}$ Herbert G. Douglass, Mensajera del Señor (Buenos Aires: Casa Editora Sudamericana, 2000), 44-131. 
En 1894 Frank C. Kelley fue a Bogotá, Colombia, como misionero de sostén propio.' Según Tirso Escandón, el colportaje desempeñó un papel de suma importancia en la iniciación de la obra adventista en Colombia. En forma específica, señala que hacia 1916 y 1917 llegaron tres colportores: Gilbert Schwerin, Harold C. Brown y George A. Neeland. ${ }^{2}$

En 1922 se realizó el primer bautismo adventista en Colombia. En 1937 comenzó a operar en Medellín la Academia Colombo-Venezolana. En 1948 la institución se transformó en el Instituto Colombo-Venezolano. Luego en 1983, éste llegó a ser la Corporación Universitaria Adventista. ${ }^{3}$

A fines del año 2001, la Iglesia Adventista en Colombia contaba con 825 iglesias organizadas, 715 grupos, 188.649 miembros, 160 pastores, 63 escuelas, 19 colegios de secundario completo, 7 colegios de secundario incompleto y una universidad. ${ }^{4}$

\section{Histona del Movimiento Koinonía en Colombia}

En el año 1977, Norberto Restrepo regresó a Colombia desde la Universidad de Andrews (Michigan, Estados Unidos), graduado como Master of Divinity y comenzó a enseñar en el Instituto Colombo-Venezolano, en la Escuela de Teología.

${ }^{1}$ Seventh-day Adventist Encyclopedia, ed. rev. 2 vols. 1996, ver “Colombia".

${ }^{2}$ Tirso Escandón, Autobiografia: Apuntes de una familia victoriosa (Riverside: por el autor, 1987), 19.

${ }^{3}$ Enoc Iglesias Ortega, Presencia adventista en Colombia (Medellin: Corporación Universitaria Adventista, 1999), 13, 17, 29, 220.

${ }^{4}$ Unión Colombiana de los Adventistas del Séptimo Día, "Informe estadístico", 30 de noviembre de 2001. 
Allí encontró gran acogida entre los estudiantes debido a que era de reconocida influencia en el territorio de la Unión Colombo-Venezolana.'

En ese primer año de actividad docente, Restrepo empezó a diseminar ideas controversiales respecto a la iglesia, la organización, el ministerio y los diezmos. Esas ideas empezaron a influir, especialmenie en los estudiantes que tenían clases con él. Aceleradamente se fueron viendo los frutos. Sus efectos trascendieron a los hogares e iglesias de donde provenían los alumnos.

La administración de la Unión Colombo-Venezolana citó a un largo diálogo a Restrepo para que diera a conocer con claridad su posición y, al mismo tiempo, para tratar de ayudarle en la clarificación de sus ideas. Pero todo fue en vano. Así transcurrieron los años 1977 y 1978. En octubre de 1978, se reunió con él la junta de la Unión Colombo-Venezolana para que tomara una decisión definitiva si quería desistir de sus ideas controversiales con respecto a la iglesia o quería continuar en su posición. Él prefirió entregar su credencial ministerial y retirarse del ministerio adventista.

$\mathrm{Al}$ año siguiente (1979), Restrepo comenzó a organizar el grupo Koinonia. Estableció su sede en Las Delicias, un lugar aledaño a la ciudad de Barquisimeto, en Venezuela.

Respecto a la administración del movimiento, desde el momento en que se inició hasta hoy, Restrepo ha sido y es el jefe único. No existe fuera de él otra autoridad con injerencia en la dirección. Guillermo Navarro, quien trabajó con

\footnotetext{
'División administrativa de la Iglesia Adventista que entonces abarcaba a
} Colombia, Venezuela y las Antillas Holandesas. 
Restrepo por un tiempo, confirma que en el movimiento no se hace nada sin la decisión de Restrepo. Su movimiento es independiente de cualquier otro grupo. Navarro añade que Ron Spear y otros líderes disidentes de los Estados Unidos son invitados por Restrepo por cuestiones ideológicas y de ayuda económica. ${ }^{1}$

Es difícil determinar cuántos forman parte de Koinonía. En los sitios de entrenamiento que tienen establecidos en lugares rurales se pueden observar grupos de veinte, treinta, y cien. Luego se disuelven y quedan cinco, diez, quince o nadie, porque después de recibir un breve entrenamiento regresan a las congregaciones de las cuales son miembros.

Las siguientes son las cifras aproximadas de participantes: en Armenia, Quindío, según John García, hay un grupo de unos ochenta. ${ }^{2}$ En la Misión de la Costa Atlántica, según Misael Durán, pueden contarse aproximadamente 14 en San Juan, 1 en Nepomuceno; 15 en Guachaca, 6 en El Carmen de Bolívar, y 10 en Cartagena. ${ }^{3}$ En Supía, Caldas, según Edilso Barrera, el grupo es de $60 .{ }^{4}$ En Bogotá, Francisco Velásquez conoce un grupo de 5 familias que suman unos 12 miembros.

${ }^{1}$ Guillermo Navarro, ex pastor adventista que se retiró del ministerio alrededor de 1990 para ingresar al ministerio independiente del grupo Koinonía y regresó a la iglesia al final del año 2002, entrevista por el autor, Bucaramanga, 23 de abril de 2002.

${ }^{2}$ John García, miembro de la Iglesia Adventista Central de Medellin, entrevista por el autor, Medellín, 5 de mayo de 2002.

${ }^{3}$ Misael Durán, director del Departamento de Ministerio Personal de la Misión de la Costa Atlántica de la Iglesia Adventista del Séptimo Día, con sede en Barranquilla, entrevista por el autor, Medellín. 3 de mayo de 2002.

${ }^{4}$ Edilso Barrera, secretario de la Misión Centro Occidental con sede en Medellín, entrevista por el autor, Medellín, 14 de mayo de 2002. 
En el distrito de Eladio Andrade hay un grupo de 35 en Tunia, Cauca. '. En Tona, un lugar aledaño a Bucaramanga, según César Amorocho, hay aproximadamente cincuenta. $^{2}$ En total son unos $280 .^{3}$

Al preguntarle sobre el tamaño numérico de Koinonía, Navarro explicó que la presencia de Koinonia en Colombia se hace visible cuando Restrepo está presente en algún lugar. Desaparece Restrepo y desaparece también el grupo porque regresan a las iglesias a las que pertenecen. Esto ocurre, según Navarro, porque Restrepo se ha constituido en la figura central del movimiento y por el concepto de iglesia que ellos manejan. Toman como punto de referencia la forma de actuar de Cristo. Él pertenecía al pueblo de Dios pero no estuvo sujeto al programa del pueblo israelita organizado, que estaba en apostasía. De esta manera, todos los que aceptan estas ideas se conciben a sí mismos como los fieles dentro de la iglesia organizada y desde allí apoyan el movimiento Koinonia. ${ }^{4}$

Sus enseñanzas son presentadas como un ministerio independiente de sostén propio y de apoyo a la iglesia. Pero lo contradictorio es que quienes siguen tales orientaciones se convierten en infatigables críticos que siembran la sospecha y la desconfianza acerca de la iglesia organizada y su ministerio.

'Eladio Andrade, pastor del Distrito de Popayán de la Asociación el Pacífico con sede en Cali, entrevista por el autor, Medellín, 14 de mayo de 2002.

${ }^{2}$ César Amorocho, estudiante del séprimo semestre de Educación Teología de la Corporación Universitaria Adventista. con sede en Medellín, entrevista por el autor, Medellín, 14 de mayo de 2002.

${ }^{3}$ Éste es, obviamente, un total provisorio.

${ }^{4}$ Navarro, entrevista 
Alberto Hernández confirma este fenómeno al observar que los miembros de iglesia asisten a estas reuniones y luego regresan a sus congregaciones con un espíritu de descontento y rebeldía.'

\section{Creencias}

Elías Jiménez observa, después de estar en contacto con miembros de Koinonía, que ellos insinúan la identificación de los fieles con aquellos que enseñan y practican la reforma pro salud, la dieta ciento por ciento vegetariana, la medicina natural y la vida en el campo. ${ }^{2}$ Afirman que la Iglesia Adventista organizada apostató en 1888; que no debe distinguirse entre pastores y laicos; que el diezmo puede ser usado al criterio del miembro; y que la organización de la iglesia es un obstáculo para hacer la obra de Dios.

La iglesia organizada apostató en 1888

El movimiento Koinonía nota que la apostasía de la Iglesia Adventista organizada comenzó con el rechazo del mensaje de justificación por la fe en el congreso de Minneápolis de 1888. Roberto Sarmiento precisa que, con la apostasía

\footnotetext{
'Alberto Hernández, pastor del Distrito Central de Medellín, de la Misión Centro Occidental con sede en Medellin, entrevista por el autor, Medellín 7 de mayo de 2002.

${ }^{2}$ Elías Jiménez, estudiante del primer semestre de Educación Teología de la Corporación Universitaria Adventista con sede en Medellín, entrevista por el autor. .Medellín. 30 de abril de 2002.
} 
de 1888 , Koinonia distingue entre la iglesia de Cristo y la iglesia organizada. ' Alicia de Sistiva explica que el concepto de iglesia para Koinonía es que "desde el principio, las almas fieles han constituido la iglesia en la tierra". 2

La efectividad de la obra está en la acción laica

La distinción entre pastores y laicos es mal vista; constituye. dicen, una jerarquía clerical. El hecho de recibir un sueldo para su sustento convierte al pastor en un asalariado. En vista de que se enfatiza una obra de preparación para la acción laica, la responsabilidad recae sobre el sacerdocio general de todos los creyentes. No se reconoce un ministerio ordenado en la iglesia organizada. ${ }^{3}$ Samuel Hennessey Taylor considera que el ministerio organizado no le permite hacer la reforma a quienes tratan de vivir el mensaje revelado a la iglesia. ${ }^{4}$

El diezmo puede ser usado a criterio del miembro de iglesia El diezmo es un recurso que el miembro de iglesia decide cómo usar. La enseñanza de Koinonía es que los diezmos deben ser utilizados para el sostén de aquellos que están predicando la verdad presente no adulterada. Así es como el

${ }^{\mathrm{I}}$ Roberto Sarmiento. miembro de la Iglesia Adventista de la Asociación del Oriente Colombiano, con sede en Bucaramanga, entrevista por el autor, Bogotá, 27 de Abril de 2002.

${ }^{2}$ Alicia de Sistiva, miembro de la lglesia Adventista de Palermo de la Asociación del Alto Magdalena con sede en Bogotá, entrevista por el autor, Bogotá, 27 de abril de 2002.

${ }^{3}$ Jiménez, entrevista.

${ }^{4}$ Samuel Hennessey Taylor, miembro de la Iglesia Central de Medellin, entrevista por el autor, Medellín, 11 de abril de 2002. 
diezmo es convertido en un elemento' de control de la calidad del ministerio. John García señala que cuando se le pregunta a Restrepo adónde se debe llevar el diezmo, él responde: "Donde haya alimento sólido de la Palabra de Dios".' Con estas ideas Restrepo capta los diezmos y donaciones de los adventistas descontentos, inconformes y resentidos.

La organización es un obstáculo para hacer la obra de Dios

La organización y estructura de la iglesia son consideradas como una maquinaria sin el Espíritu, razón por la cual constituyen un obstáculo para realizar la obra de Dios. Según Navarro, Restrepo cree que Jesús perteneció al puebio de Dios cuando desarrolló su ministerio terrenal, sin someterse a la organización de la comunidad israelita. $^{2}$ Roberto Sarmiento confirma que Koinonía asevera que la apostasía de la que es acusada no es de la iglesia de Cristo sino de la iglesia organizada. ${ }^{3}$

Las creencias que el movimiento Koinonia sostiene son alimentadas mediante algunas estrategias. Éstas se describen a continuación.

\section{Estrategias}

Distribución de literatura

El movimiento Koinonia no posee una literatura propia para difundir sus

'García, entrevista.

${ }^{2}$ Navarro, entrevista.

${ }^{3}$ Sarmiento, entrevista. 
posiciones. Navarro aclara que Restrepo arguye que cuando Cristo estuvo en esta tierra no escribió nada en absoluto.' Por ello, Koinonia distribuye la literatura que producen los movimientos disidentes en los Estados Unidos y que conviene a sus propósitos ideológicos y económicos. Entre los adventistas hacen circular la revista Nuestro firme fundamento, de la organización disidente Hope International, ${ }^{2}$ y varios folletos. $^{3}$

Conferencias y seminarios

Las conferencias y seminarios son llevados a cabo en los hogares de los

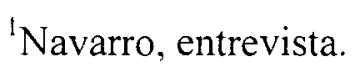

${ }^{2}$ Issues: The Seventh-day Adventist Church and Certain Private Ministries (Silver Spring, MD: North American Division, 1992), 11, 13, 15. Hope International es un un ministerio independiente, liderado por el pastor jubilado Ron Spear, quien pretende que su ministerio es de apoyo a la iglesia. Su crítica destructiva ataca al ministerio y los lideres de la iglesia. Sus intentos son de reformar su teología y purificarla de aquellos que se oponen a sus ideas. Sus esfuerzos también están dirigidas los dineros de la tesorería adventista. El corazón del problema está en que Hope International exige que la iglesia y su liderazgo debe aceptar su posición, porque de lo contrario son declarados culpables de herejía, y sus puntos de vista se constituyen en una evidencia de apostasía de la iglesia. Sus acciones demuestraique los miembros de Hope International no pueden ser considerados miembros de la Iglesia Adventista de ninguna manera.

${ }^{3}$ Ron Spear, Una carta abierta a los miembros de la Asociación de Washington de los Adventistas del Séptimo Día (Eatonville. WA: Hope International, 1994); Dave Fiedler, El adventismo y Walter Martin (Eatonville, WA: Hope International, 1991); [Elena G. de White], Salid de las ciudades (Barquisimeto: Fundación Las Delicias, s.f.); Dennis E. Priebe, ¿Qué es pecado?.Cara a cara con el verdadero evangelio (Barquisimeto: Fundación Las Delicias, s.f.);Idem, ¿Cómo vivió Cristo?, Cara a cara con el verdadero evangelio (Barquisimeto: Fundación Las Delicias, s.f.): Idem. La imposibilidad del hombre, la posibilidad de Dios. Cara a cara con el verdadero evangelio (Barquisimeto: Fundación Las Delicias, s.f.): Árboles de justicia y el mensaje de 1888 (Cali: Koinonía, s.f.); Alonzo Jones. Individualidad en religión (Dichendorf, Alemania: Botschaft für unsere Zeit, 1987.) 
adventistas que simpatizan con el movimiento. El hogar anfitrión se encarga junto con otros simpatizantes, de hacer propaganda secreta en la congregación adventista, invitando a las reuniones. Las reuniones son realizadas también en lugares como hoteles, en ellas dan entrenamiento a los laicos. ${ }^{1}$

\section{Permanecer en la iglesia como miembros}

García dice que Restrepo aconseja a los que simpatizan con su movimiento a permanecer en la iglesia, desde donde apoyan el movimiento. Los que son desfraternizados continúan asistiendo, reclamando ser adventistas, pero manteniendo un espíritu hostil y crítico hacia la iglesia organizada y su liderazgo. ${ }^{2}$

Contactos con personas que manejan recursos económicos

Los contactos con miembros de iglesia y simpatizantes de la misma que manejan ciertos recursos económicos son blanco de conquista para el movimiento Koinonia. Al preguntarle a Navarro sobre esta estrategia respondió de manera indirecta y en forma metafórica: "Lo único que sé decirle es que Norberto, sí. sabe dónde ponen las garzas". ${ }^{3}$ El pastor Walter Ramos Escobar confirma que el movimiento atrae a ciertas personas con recursos. ${ }^{4}$

${ }^{1}$ García, entrevista.

${ }^{2}$ Tbíd.

${ }^{3}$ Navarro, entrevista.

${ }^{4}$ Walter Ramos Escobar, capellán del sanatorio de Supía. Caldas, de la Misión Centro Occidental con sede en Medellín, entrevista por el autor. Medellín, 29 de abril de 2002. 
Educación para laicos

En los lugares rurales establecidos por el movimiento se reclutan laicos, adultos y jóvenes. Alli se entrenan en vida familiar, vida natural, ecología, nutrición y agricultura.'

Nelson Vargas comenta la experiencia que han tenido en Bucaramanga con los miembros que han asistido a estos lugares. Después de haberlos cautivado con el programa, enfatizan todo lo negativo de la iglesia. Así destruyeron una congregación en Bucaramanga. ${ }^{2}$

El choque frontal del movimiento Koinonia con la Iglesia Adventista radica en que aquel tomó la bandera de la reforma pro salud y la vida en el campo, y la enarboló en un asta tan elevada que es lo único que pueden divisar sus adeptos y quienes los escuchan. Bajo la sombra de su bandera no se logra ver la riqueza global de la revelación que ha recibido la Iglesia Adventista del Séptimo Día. En apoyo a esta realidad, Jiménez manifiesta que Koinonia ha hecho de la reforma pro salud y de la vida en el campo una prueba de discipulado. ${ }^{3}$

El movimiento Koinonía no tiene una teología ni un sistema de doctrinas como base sobre la cual puedan fundamentar o expresar su posición. La fuente de autoridad que usan para respaldar sus convicciones y posiciones son las Sagradas

. 'Hope International, "Fundación Educativa Salud Integral para el Desarrollo Integral del Hombre", Nuestro firme fundamento 6 (1989): 32.

${ }^{2}$ Nelson Vargas, secretario de la Asociación del Oriente con sede en Bucaramanga, entrevista por el autor, Bucaramanga, 23 de abril de 2002.

3 Jiménez, entrevista. 
Escrituras y los escritos de Elena G. de White.

Concluyendo, se puede apreciar que el movimiento Koinonia enfrenta un problema eclesiológico que requiere evaluación. En los capítulos 3 y 4 se destacarán los elementos esenciales de eclesiología que encontramos en el Nuevo Testamento y en los escritos de Elena de White, respectivamente. Luego, en el capítulo 5 se hace una evaluación de algunos aspectos de la eclesiología del grupo Koinonía, tales como la iglesia y apostasía, la organización, y el uso del diezmo. 


\section{CAPÍTULO III}

\section{LA IGLESIA EN EL NUEVO TESTAMENTO}

\section{La palabra ekklēsia}

Comenzaremos con un breve examen del significado del vocablo ekklēsia en la cultura griega. Luego se estudiará el uso del término en el Nuevo Testamento.

\section{En el griego clásico}

En la cultura griega de los tiempos de la Atenas clásica, la ciudad tenía una asamblea legislativa para tratar los asuntos públicos del estado libre. Esta asamblea se denominaba ekklēsía. ${ }^{1}$ Estaba integrada por los ciudadanos cuyos derechos cívicos estaban en regla (los ekklētoi, "llamados" por el heraldo a reunirse en asamblea). Las decisiones que allí se tomaban debían estar en armonía con las leyes del estado. ${ }^{2}$ En forma general, el término ekklēsia estaba asociado con "cualquier asamblea de ciudadanos convocados". 3

Una breve lista de las diferentes responsabilidades de esta asamblea revela la misión y naturaleza de la misma: nombraba y destituía a los magistrados; dirigía la

${ }^{1}$ Francisco Lacueva, Curso de formación teológica evangelistica, vol. 6, La iglesia cuerpo de Cristo (Barcelona: CLIE, 1973), 24.

${ }^{2}$ Willian Barclay, Palabras griegas del Nuevo Testamento (Buenos Aires: Casa Bautista, 1977), 53.

${ }^{3}$ Ibid., 53. 
política de la ciudad; declaraba la guerra y hacía la paz; asumía los compromisos y concertaba las alianzas; elegía a los generales y otros oficiales militares; y recogía y distribuía los fondos públicos. ${ }^{1}$

Cuando la asamblea tenía que deliberar sobre el caso de algún ciudadano en particular, en el que estaban implicados sus derechos, éste tenia que estar presente y no se daba trámite al problema si no había una representación mínima "de seis mil ciudadanos".

El vocablo ekklèsia era de uso común entre los autores griegos. Consta de la preposición ek, "fuera de", y klēsis, "llamamiento". Klēsis deriva del verbo kaleō, "llamar". Por lo tanto, el significado correcto de ekklèsia es "llamar fuera de". 3 Los ciudadanos griegos que no habían perdido sus derechos cívicos eran llamados a salir de sus casas para reunirse en asamblea con el fin de atender las necesidades de la ciudad.

La ekklēsia de las ciudades griegas era esencialmente una asamblea para tratar asuntos seculares. Esto no impedía que se ofreciesen normalmente una o más oraciones a los dioses como parte de cada sesión. ${ }^{4}$

No hay evidencia de que entre los griegos precristianos, ekklēsia designase

${ }^{1}$ Ibíd.

${ }^{2}$ Ibid., 53-54.

${ }^{3}$ W. E. Vine, Diccionario expositivo de palabras del Antiguo y Nuevo Testamento (Bogotá: Caribe, 1999), 64, 88, 90.

${ }^{4}$ K. L. Schmidt, "ekklessia", Theological Dictionary of the New Testament, 10 vols. (Grand Rapids: Eerdmans, 1964-1976), 3: 514. 
una sociedad o agrupación religiosa. Esto cambiará cuando el vocablo sea usado en el Nuevo Testamento, influido por el uso de ekklesia en la Septuaginta, la versión griega del Antiguo Testamento completada más de un siglo antes del nacimiento de Cristo. ${ }^{1}$

\section{En el Nuevo Testamento}

El concepto de ekklēsia en el Nuevo Testamento está fuertemente influido por el uso de la Septuaginta. En esta versión, ekklēsia aparece unas cien veces, unas setenta de ellas como traducción del hebreo qahal (congregación, asamblea, reunión). En tiempos de Jesús, la Septuaginta era muy conocida y usada. Los judíos que hablaban griego estaban familiarizados con el vocablo ekklesia.

En el Antiguo Testamento, qahal no siempre designa una congregación o asamblea relacionada con asuntos espirituales. ${ }^{2}$ Cuando el texto hebreo agrega "de Jehová" (Nm. 16:3; 20:4; Dt. 23:1, 3, 8), ${ }^{3}$ o "de Dios" (Neh. 13:1). ${ }^{4}$ Es claro que qahal (ekklessía en la septuaginta) se refiere a una asamblea religiosa.

También debe tenerse en cuenta el proceso o el hecho de reunirse. Sin embargo, lo que define no es que algunos se reúnan, sino quién se reúne. Dios es el que reúne, y la ekklēsia se constituye así en comunidad de Dios.

'Diccionario bíblico adventista del séptimo día, ed. 1995, ver "iglesia".

${ }^{2}$ Véase, por ejemplo, 1 Cr. 29:1; 2 Cr. 28:14; Sal. 26:5; Ez. 23:46.

${ }^{3}$ Las citas bíblicas usadas en este trabajo han sido tomadas de la versión Reina-Valera 1960 de las Sociedades Bíblicas en América Latina.

${ }^{4} J$ hohannes B. Bauer, Diccionario de teología bíblica, ed. 1967, ver "iglesia". 
Jesús va más allá del Antiguo Testamento en la creación de su iglesia. Sus seguidores conforman una "asamblea" o "congregación" religiosa diferente de las del ambiente judío y griego. ${ }^{1}$ El qahal estaba circunscrito a los límites de una nación; la ekklēsia de Jesús y de los apóstoles trasciende las fronteras, las razas y los credos. ${ }^{2}$

\section{La iglesia que describe el Nuevo Testamento}

En el Nuevo Testamento, el vocablo ekklēsia aparece 114 veces. De ellas sólo tres aparecen en los evangelios, 23 en los Hechos, una en Santiago y veinte en Apocalipsis. Las veces restantes aparecen en los escritos del apóstol Pablo. ${ }^{3}$

La comunidad cristiana primitiva tomó la denominación de ekklessia Se apropió conscientemente del derecho de ser la verdadera "asamblea" o "congregación" de Dios, el verdadero pueblo de Dios. El Padre celestial mismo, por medio de Jesús, ejerce su señorío sobre la iglesia (Mt. 16:18; véase también Jn. 5:30; $6: 38)$.

Al reflexionar sobre el mensaje de Jesús acerca de la iglesia se observa que sólo dos versículos en los evangelios contienen el vocablo ekklēsia (Mt. 16:18; y 18:17). Cristo funda la iglesia pero usa apenas tres veces en Mateo el vocablo que la identifica. En cambio, en el texto de los evangelios se emplea 51 veces el término "reino de Dios". 1995), 25.

'Raúl Caballero Yoccou, Sobre esta roca edificaré mi iglesia (Miami: Unilit,

${ }^{2} J$ n: 4:21, 23-24; Ro. 9: 6-8; Col. 3:11.

${ }^{3}$ Hugo M. Petter, Concordancia greco-española del Nuevo Testamento (Barcelona: CLIE, 1976), ver "iglesia". 
Esto sugiere la necesidad de analizar primero el significado de "reino de Dios" en las enseñanzas de Jesús y luego el de "iglesia".

El reino de Dios en las enseñanzas de Jesús

Mateo usa la frase "reino de Dios" cinco veces solamente. ${ }^{1}$ Por otra parte, menciona 28 veces la expresión "el reino de los cielos", frase no distinta sino sinónima, tratando quizá de evitar por reverencia judaica el nombre de Dios. ${ }^{3}$ Los otros evangelistas, Marcos, Lucas y Juan, usan la frase "el reino de Dios" 47 veces, ${ }^{4}$ El reino de Dios es la nota dominante de la predicación de Jesús. Según Roland Leavell, "el tema central del evangelio de Mateo, el reino de los cielos, es el asunto más excelso del cielo o la tierra".5 Bill J. Leonard agrega: "El evangelio de Jesucristo es el evangelio del reino de Dios. Desde el comienzo de su ministerio, Jesús declaró las buenas nuevas del reino diciendo: 'El tiempo se ha cumplido, el reino de Dios se

${ }^{1}$ Petter, ver "reino de Dios". Mt. 6:33; 12:28;19:24; 21:31, 43.

${ }^{2}$ Petter, ver "reino de los cielos". Mt. 3:2: 4:17: 5:3. 10. 19. 20: 7:21: 8:11: $10: 7 ; 11: 11,12 ; 13: 1$ $23: 13 ; 25: 1$

${ }^{3}$ Gerardo Sánchez Mielgo, Evangelios sinópticos (Bogotá: Universidad Santo Tomás, 1983), 41.

${ }^{4}$ Petter, ver "reino de Dios" Mr. 1:15; 4:11, 26, 30; 6:23; 9:1,47; 10:14, 15, 23, 24,$25 ; 12: 34 ; 14: 25 ; 15: 43$ Lc. $4: 43 ; 6: 20 ; 8: 1,10 ; 9: 2,11,27,60,62 ; 10: 9 ; 11: 20$; $12: 31 ; 13: 18,20,28,29 ; 16: 16 ; 17: 20,21 ; 18: 16,17,24,25,29 ; 19: 11 ; 20: 31 ; 22: 16$, $18 ; 23: 51 ;$ Jn. $3: 3,5 ; 18: 36$.

${ }^{5}$ Roland Leavell, Mateo: El rey del reino, trad. Alfredo Quezada (El Paso, TX: Casa Bautista, 1988). 
ha acercado; arrepentíos y creed en el evangelio’ (Mr. 1:15)".'

"El tiempo se ha cumplido y el reino se ha acercado". El contexto de los evangelios sugiere que el reinado de Dios, del cual habla Jesús, es el reino escatológico, que se realizará plena y efectivamente al fin del mundo. Como acontecimiento. "se ha acercado"2. El reino de Dios vendría "con poder" (Mr. 9:1). ¿Qué hace tan urgente el mensaje de Jesús, "el tiempo se ha cumplido y el reino de Dios se ha acercado" (Mr. 1:15)? Se trata de una iniciativa divina. Nadie puede invitarse a sí mismo al banquete escatológico. Sólo "el rey" invita (Mt. 22:2, 9). El hombre sólo puede orar "venga tu reino" (Mt. 6:10; Lc 11:2). Puede clamar a Dios "día y noche" (Lc. 18:7); puede buscar el reino de Dios (Mt. 6:33; Lc. 12:31); puede luchar por él (Lc. 13:24; cf. Mt. 7:13); puede prepararse y estar alerta como las vírgenes prudentes (Mt. 25:1-13) o los siervos vigilantes (Lc. 12: 37-38, cf. Mt. 24:44-47). No es el hombre sino Dios quien "da" el reino (Lc. 12:32). Él lo deja asignado (Lc. 22:29-30). Él dice para quién es el reino (Mt. 5:3, 10; Lc. 6:20). Dios es el rey, no está sujeto a nuestros cálculos ni razonamientos en su soberanía y libertad. Actúa para ejecutar su propio querer, incondicionalmente libre. No es el hombre, sino Dios quien dispone de su reino. El hombre no puede conquistar el reino de Dios, sino sólo recibirlo como un niño (Mr. 10:15).

'Bill J. Leonard, La naturaleza de la iglesia, trad. Clark H. Stanley (El Paso TX: Casa Bautista, 1989), 133.

${ }^{2}$ Rudolf Schnackenburg, Reino y reinado de Dios, $3^{\text {a }}$ ed., trad. José Coscaya Osa (Madrid: Fax, 1974), 133; ver, Mr. 1:15; Mt. 12:28; Lc. 11:20; 22:18; Mr. 14:25; Mt. 26:29. 
Según Sánchez Mielgo, el pensamiento zelota hacía depender la llegada del reino de Dios de su propia "acción". Creían que dicho reino se haría presente si se aportaba una acción "sinergética con Dios". La conversión, para ellos, tenía el sentido de solidaridad "con la acción revolucionaria y exigía la entrega total de la vida hasta el martirio si las circunstancias así lo querían". Aun tal colaboración la enfocaban "en la guerra santa a modo de guerrillas (como en la época macabeica)".

\section{No es un reino temporal}

Según Jesús, el reino de Dios no es una teocracia que se establecerá en este mundo (Jn. 18:36). Es un reino puramente espiritual (Jn. 18:37; cf. 14:6; 17:16-17). Jesús rechaza constantemente las expectativas de un reino temporal, acompañado de la liberación del dominio extranjero y de toda miseria, (Hch. 1:6; Jn. 15:19; 18:36).

Las expectativas mundanas, ${ }^{2}$ la ambición por ocupar puestos de honor en el reino temporal (Mr. 10:35-45) y procedimientos utilitarios o violentos no caben en este reino ${ }^{3}$.

Cristo reprendió duramente a Pedro por permitirle a Satanás que lo usara como instrumento para tratar de desviar a su Maestro de su misión (Mr. 8:31-33). Jesús rechazó los cálculos sobre la fecha de llegada de su reino. El reino de Dios no vendrá con advertencia (Lc. 17:20), sólo el Padre sabe la hora (Mr. 13:32). Imágenes como las del banquete sugieren que no son una descripción real del reino de Dios,

\footnotetext{
'Sánchez Mielgo, 44.

${ }^{2}$ Lc. 19:11; 23:42; 24:21; Hch. 1:6.

${ }^{3}$ Mr. 14:17-21. cf Jn. 13:1-4, 10, 18. 21, 26-27; Lc. 22:28-29.
} 
sino una confirmación de su realidad; que no significa el placer de la mesa, sino el acto de la comunión con Dios y los demás. (Mt. 22:1-13;25:1-3; Lc. 15;17-32).

A pesar de que la predicación de Jesús atraía por su pureza y claridad, era rechazada por la mayoría del pueblo y por sus dirigentes. Lo hacían porque el reino de Dios anunciado por Jesús no era un reino de poder político ni de bienes terrenales, sino de la soberanía de Dios, que exige arrepentimiento y fe: "El reino se ha acercado; arrepentíos y creed en el evangelio" (Mr. 1:15).

Santos Sabugal explica que los contemporáneos de Jesús, su pueblo, se frustraron en sus expectativas y lo rechazaron. Esperaban "un hombre dotado de excepcionales cualidades". Como Ungido debía ser "un rey carismático e hijo (adoptivo) de Dios". Como rey temporal debía ser "jefe guerrero libertador y Salvador de Israel de la opresión de sus enemigos, personificados en Gog y Magog, a quienes en encarnizada lucha, derrota y aniquila".

\section{Es el reino de la gracia}

El reino de Dios anunciado por Jesús no era un juicio vengativo de Dios sobre los pecadores, sino el ofrecimiento de salvación a los perdidos. El llamado de Jesús al arrepentimiento no estaba unido a la ira de Dios, como en Juan el Bautista, sino a su gracia. El mensaje del reino de Dios que trajo el Mesías no era de amenaza ni perdición, sino de salvación, gozo y paz. No son malas sino buenas noticias. "Creed en el evangelio" (euaggelion = buenas nuevas, Mr. 1:15). Este evangelio no sólo

'Santos Sabugal, Christos: Investigación exegética sobre la cristologia joannea (Barcelona: Herder, 1972). 51-52. 
estaba dirigido no sólo a una raza y nación, no sólo a los ricos y poderosos, sino también a los pobres y tristes, a los despreciados.

Para no perder el enfoque del mensaje de Jesús se puede afirmar con Francisco López "que el punto central de las enseñanzas del maestro no es la cuestión social, sino el reino de Dios".' Virgilio Zea concuerda con López cuando señala: "Jesús no hace de su propia persona el centro de su predicación; existe un tema fundamental que le da unidad: el REINO DE DIOS y su llamado al cambio total de la persona y de sus relaciones (Lc. 19)". ${ }^{2}$

Jesús no dirige su mensaje sólo a los justos, sino también a los perdidos ${ }^{3}$. El escándalo para los que se justificaban a sí mismos (Lc. 8:9-14) se debió a que Jesús se relacionó con los pecadores más notorios, como los publicanos. las rameras y los samaritanos. ${ }^{4}$ La teología de Cristo acerca del reino de Dios apuntaba precisamente a ayudar al pecador, porque "una teología que no ayude a superar las crisis y desafíos de la vida diaria no es útil", anota George R. Knight. ${ }^{5}$ A todos Jesús les predicaba la gracia, la misericordia y el perdón de Dios. La revelación del amor de Dios a los

${ }^{1}$ Francisco María López, Pobreza y riqueza en los evangelios (Madrid: Studium, 1963), 3.

${ }^{2}$ Virgilio Zea, Jesús, el Hijo de Dios (Bogotá: Universidad Santo Tomás. 1989), 64 .

${ }^{3}$ Mt. 9:12-13; Mr. 2:17; Lc. 5:31-32; Jn. 3:17.

${ }^{4}$ Mt. 9: 9-11; Mt. 21:31; Mr. 2:13-16; Lc. 5:27-30; Jn. 4:9. 39.

${ }^{5}$ George R. Knight, Guia del fariseo para una santidad perfecta: Un estudio sobre el pecado y la salvación. trad. Silvia González (Bogotá: Asociación Publicadora Interamericana, 1998), 11. 
pecadores se convierte en señal del advenimiento del reino de Dios. ${ }^{1}$ Jesús anunció el reino de Dios de manera tan enfática, porque a todos. aun a los perdidos, les llega la salvación bajo una sola condición: "Arrepentíos y creed en el evangelio" (Mr. $1: 15)$

La iglesia en el pensamiento de Jesús

Las referencias a la enseñanza del Mesías durante su ministerio terrenal y las alusiones que hizo a la iglesia, están enteramente ligadas con las enseñanzas acerca del reino. Sólo se refirió a la iglesia como un instrumento para el establecimiento de su reino en este mundo (Mt. 10:1, 5, 7; 25:31,34).

Sólo el evangelio de Mateo registra dos referencias explícitas a la ekklēsia en las enseñanzas de Jesús. Son de gran relevancia por encontrarse en el documento que es de manera particular el evangelio del Rey y del reino. Si hubiese existido alguna contradicción entre la idea del reino y de la iglesia. el evangelista hubiera evitado referirse a la iglesia, puesto que su pasión era el reino y su visión del Rey. Según Ernesto Trenchard, Mateo presenta "distintos aspectos de la persona, la obra y las enseñanzas del Mesías Rey". ${ }^{2}$

\section{Jesús promete edificar su iglesia}

Después de la confesión de Pedro (Mt. 16:16), Jesús hizo la declaración explícita "edificaré mi iglesia" (Mt. 16:18) y prometió dar a Pedro "las llaves del

J.J. $3: 16 ; 15: 12-15 ; 17: 23,26$.

${ }^{2}$ Ernesto Trenchard. Introducción a los cuatro evangelios, $2^{\mathrm{a}}$ ed. (Madrid: Literatura Bíblica, 1981), 36. 
reino de los cielos" (Mt. 16:19). Posteriormente se dirigió a los apóstoles como conjunto (Jn. 20:19-23) y se refirió también a la iglesia como comunidad de creyentes en el contexto de la disciplina eclesiástica (Mt. 18:15-18). William Evans comenta que en Mt. 16:16-18 Pedro no recibe una investidura de supremacia de parte de Cristo, sino que, según Juan 20: 19-23 y Mt. 18:18, también "se da el mismo privilegio de atar y desatar a toda la iglesia y a todos los apóstoles". 1

Hablando de Mt. 16:18, H. E. Dana pregunta si el significado del texto se ha de tomar sólo en el sentido en que lo recibieron los discípulos que estaban presentes en el momento, o si se lo puede interpretar "en lo que a su significado final en la promoción del reino concierne". Si el término iglesia sólo quiere decir lo que los discípulos presentes oyeron de labios de Jesús, dice él, "“mi ekklēsia" meramente significó el traspaso de la antigua congregación de Israel a una nueva final relación con Cristo". La idea que Jesús puso en la mente de ellos, era la imagen de la ekklēsia o qahal de Israel, puesto que ésta era la connotación vivencial "del término en el pensamiento judío". H. E. Dana cree que como Jesús no hablaba griego sino arameo, posiblemente usó el término arameo equivalente a qahal, indicando que "su propósito era edificar una nueva congregación, distinta de la antigua congregación de Israel".2

\footnotetext{
'William Evans, Las grandes doctrinas de la Biblia, trad. M. Garrido Aldama (Chicago: Moody, 1960), 181.

${ }^{2}$ H. E. Dana, Manual de eclesiología, trad. Adolfo Robleto y otros (El Paso, TX: Casa Bautista, 1987), 15-16.
} 
Por otro lado, el mismo Dana infiere que el texto de Mt. 16:18 no difiere de Mt. 18:17-18 en su sentido, sólo que Mt. 18:18 "es ampliado en la misma forma, aunque con un significado local más enfático".

Otro incidente en el que Jesús parece relacionar la iglesia y el reino es la petición que la madre de los dos hijos de Zebedeo hace a Jesús de sentar a sus dos hijos, uno a la derecha y el otro a la izquierda, en su reino. En respuesta, el Maestro les enseñó cuál era la ley de la grandeza en la iglesia, y la puso en contraste con los reinos de los hombres (Mt. 20:20-28). "Los gobernantes de las naciones" miden su grandeza por el nivel de su autoridad. "Entre vosotros no será asi". Una posición de grandeza en la iglesia no se fundamenta en ejercer la mayor autoridad, sino en ceder a ella. El grado inferior, según el mundo que ha olvidado a Dios, es el del siervo. En cambio, el que sirve es el mayor en el reino de Dios. El afán supremo entre los seguidores del Mesías en el reino no será gobernar sino servir.

Se suma a estas referencias el juicio simbólico que Jesús hizo sobre una higuera, en el camino hacia Jerusalén, entre aquellos últimos actos con los que puso a un lado a la nación hebrea (Mt. 21:43). Con este hecho le dio a entender al grupo, que si en su desempeño corporativo ejercitaban la fe, sus realizaciones en el cumplimiento de la misión serían más abarcantes. Contrastó el poder de la fe con el fracaso de aquellos que la habian perdido y que, por lo tanto, eran como la higuera, condenada al juicio. El Maestro amonestaba a quienes iban a construir la iglesia.

\footnotetext{
'Ibíd.
} 


\section{Jesús anuncia la transferencia del reino}

Mediante la declaración "El reino será quitado de vosotros, y será dado a la gente que produzca frutos de él" (Mt. 21:43), Cristo anticipa la transferencia de la responsabilidad del reino, de manos de Israel, a la nueva ekklēsia que estaba por edificar.

En las orientaciones del Mesías a sus discípulos, al revelarles el fracaso de los escribas y fariseos, reconoció primero la posición oficial que ellos habían ocupado en la economía divina: "En la cátedra de Moisés se sientan los escribas y fariseos. Asi que todo lo que os digan que guardéis, guardadlo y hacedlo; mas no hagáis conforme a sus obras, porque dicen, y no hacen" (Mt. 23:2-3). Luego continúa: "Vosotros no queráis que os llamen Rabí" (v. 8). Con ello se revelan el orden del nuevo reino y el secreto de la autoridad: "Porque uno es vuestro Maestro, el Cristo, y todos vosotros sois hermanos, ... porque uno es vuestro Padre, el que está en los cielos" (vv. 8-9). Toda enseñanza tenía por objetivo mostrar a su círculo íntimo cómo se ejercía la autoridad moral; no asignándose los títulos que reclamaban los rabinos, sino siendo . enseñados por el gran Maestro; no cediendo a una falsa autoridad. sino reconociendo su relación con la autoridad del cielo, y su derecho de acceso al Padre celestial para descubrir su voluntad, y ejercer su autoridad en el mundo.

Poco después, en la fase final de la fiesta judía de la Pascua, el Señor estuvo presente. Su enseñanza en esta festividad fue precisamente el hecho de la transferencia de la Pascua, de la antigua a la nueva dispensación (Mt. 26:27-29). Con la Pascua se celebraba la hora en que Dios había liberado a Israel de la esclavitud egipcia (Ex. 12:12-14). La Pascua se convertiría ahora en monumento de liberación 
espiritual. Israel partió hacia el Sinaí como pueblo de Dios bajo la antigua dispensación. Pero ahora, como lo dijo Pablo: "Nuestra pascua que es Cristo, ya fue sacrificada por nosotros" (1 Co. 11:23-26). Mediante ella se restaura la soberanía espiritual del reino.

En relación con la transferencia ya mencionada, el Mesías se refirió a otra transferencia que realizaría en el futuro: "No beberé más de este fruto de la vid, hasta aquel día en que lo beba de nuevo con vosotros en el reino de mi Padre" (Mt. 26:29). Proyectando su mirada hacia un futuro distante, hizo alusión al día al cual el apóstol Pablo se refirió vislumbrando el futuro: "Luego el fin, cuando entregue el reino al Dios y Padre, cuando haya suprimido todo dominio, toda autoridad y potencia" (1 Co. 15:24). La esencia de todo ello es el reino, su restablecimiento por la victoria del Mesías.

Finalmente viene la reunión en el monte de Galilea (Mt. 28:7-16), la única aparición después de la resurrección que registra Mateo. Las palabras de despedida fueron: "Toda potestad me es dada en el cielo y en la tierra. Por tanto, id, y haced discípulos a todas las naciones. bautizándolos en el nombre del Padre y del Hijo y del Espiritu Santo; enseñándoles que guarden todas las cosas que os he mandado; y he aquí yo estoy con vosotros todos los días, hasta el fin del mundo" (Mt. 28: 18-20). Ésta es la voz del rey y la comisión del reino; es la declaración de que su iglesia ha de ir a todas las naciones.

De acuerdo con Dn. 9:24, se puede decir que la iglesia que anunció Jesús en Mateo 16:18 y 18:17, ha reemplazado al pueblo hebreo en la economía de Dios. 
Cristo la fundó en su plenitud después de su resurrección, ${ }^{1}$ como su instrumento, con el propósito de hacerla su vocera en la proclamación del reino de los cielos ${ }^{2}$. Pablo amplía la visión eclesiológica.

La iglesia en el pensamiento paulino

En las epístolas paulinas, si incluimos Hebreos, el vocablo ekklēsia se registra 63 veces. $^{3}$

En muchos pasajes el apóstol habla de la ekklèsia en plural ${ }^{4}$. Singular y plural se entrecruzan a menudo; a veces se emplea el artículo, otras no. En muchos casos se nombra el lugar de la iglesia. Éste es a menudo el nombre de una ciudad: Tesalónica (1 Ts. 1:1;2 Ts. 1:1), Corinto (1 Co. 1:2; 2 Co 1:1). Cencrea (Ro. 16:1), Laodicea (Col. 4:16). A veces es también el nombre de una región: Asia (1 Co. 16:19), Galacia (1 Co. 16:1; Gá. 1:2), Macedonia (2 Co. 8:1), Judea (Gá. 1:22; 1 Ts. 2:14). La reducida comunidad cristiana doméstica también merece para el apóstol el nombre ekklēsia (Ro. 16:5; Fil. 2:2; cf. Col. 4:15), y hasta es equiparada con las comunidades mayores (1 Co. 16:19). Se les da expresamente el título iglesia. Dana sostiene que "1 Cor. 12:28 indudablemente indica alguna idea general de la iglesia,

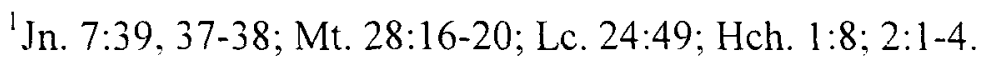

${ }^{2}$ Jn. 18:36-19:16; Hch. 7:54-60; 8:4.

${ }^{3}$ Petter, ver "iglesia". Ro. 16:1, 4, 5, 16, 23; 1 Co. 1:2; 4:17; 6:4; 7:17; 10:32; $11: 16,18,22 ; 12: 28 ; 14: 4,5,12,19,23,28,33.34 .35 ; 15: 9 ; 16: 1,19 ; 2$ Co. $1: 1 ; 8: 1$, $18,19,23,24 ; 11: 8,28 ; 12: 13$; Gá. 1:2. 13, 22; Ef. 1:22; 3:10, 21:5:23. 24. 25, 27 , 29, 32; Fil. 3:6; 4:15; 1Ts. 1:1; 2:14; 2 Ts. 3:5, 15; 5:16; Flm.2; He. 2:12; 12:23.

${ }^{4}$ Petter, ver "iglesias". Ro. 16:4,16; 1 Co. 11:16; 14:33; 2 Co. 8:18; 11:8; 12:13; Gá. 1:2,22. 
siendo que no es posible aplicar la afirmación a la congregación particular de Corinto". A continuación añade: "Ningún apóstol jamás mantuvo una relación oficial con ninguna iglesia como independiente de las demás".

El hecho concreto de que las iglesias se reúnan para adorar a Dios se expresa claramente en 1 Co. 11:18,20,33; 14:23; cf 14:26. Sólo en la carta a los Efesios Pablo presenta la iglesia universal en el primer plano de su consideración, en un sentido nuevo, sobre todo en la relación con la única iglesia compuesta de judíos y gentiles (Ef. 2:11; 3:6; 4:17). Dios obra por medio de Jesucristo. Así las iglesias que están en Cristo Jesús (1 Ts. 2:14; Gá. 1:22), son iglesias de Jesucristo (Ro. 16:16). Desde este punto de vista etimológico, ekklēsia no significa más que el pueblo de Dios. Así lo confirma Joaquín Jeremías al decir que "ekklēsia, en su realidad objetiva, no debe traducirse por iglesia sino por pueblo de Dios".

\section{Iglesia, congregación y comunidad}

"Iglesia", "congregación" y "comunidad" son tres palabras que deben unirse en mutua dependencia y no en contraposición. Los términos no compiten entre sí, sino que se complementan en la traducción variada del término ekklēsia.

Por otra parte, la iglesia universal no es la suma de las iglesias locales. Las comunidades de los diferentes lugares son denominadas con el nombre de ekklēsia y es de notar que el singular y plural se emplean indistintamente. Aunque Pablo no

\footnotetext{
'Dana, 18, 17-20.

${ }^{2}$ Joachim Jeremías, Teología del Nuevo Testamento. $2^{\mathrm{a}}$ ed., trad. Constantino
} Ruiz Garrido (Salamanca: Ediciones Sígueme 1974), 200, 199-201. 
define ni teológica ni juridicamente la relación entre la iglesia local y la universal, es sin embargo cierto que las iglesias particulares están unidas por algo más que el nombre común ekklēsia, por algo más que su nexo externo, por algo más que una organización superior a las iglesias locales. A cada iglesia en particular se le ha dado el mismo y único evangelio, los mismos dones y promesas. Todas están bajo la gracia del único Dios y Padre, tienen el mismo y único Señor y están regidas por el mismo Espíritu Santo que opera por sus carismas y ministerios. Todas creen la misma y única fe, se santifican por el único bautismo y se alimentan de la misma y única esperanza (1 Co. 12:4-7; Ef. 4:5-7). Por todo esto, no sólo están estrechamente ligadas, sino también interiormente unidas; entre todas no forman una organización eclesiástica, sino una iglesia, la iglesia de Cristo. Dana, por su parte, afirma que "esta ekklēsia es universal en el sentido de que la bendición de la unión en Cristo y con el resto de los redimidos por Cristo, es la herencia común de todos los creyentes en todas las edades". Y añade: "No es universal en el sentido de abarcar a todas las iglesias en alguna forma objetiva de organización".

\section{Cristo en las epístolas paulinas}

Jesús enfatizó la frase "reino de Dios" ("reino de los cielos"). Pablo, en cambio, usa más frecuentemente el vocablo ekklēsia. En todas sus epístolas, ekklēsia aparece 63 veces, mientras que el "reino de Dios" sólo es mencionado 17 veces. ${ }^{2}$

'Dana, 23.

${ }^{2}$ Petter, ver "reino". Ro. 14:17; 1 Co. 4:20; 6:9, 10; 15:24, 50; Gá. 5:21; Ef. 5:5; Col.1:13; $4: 11 ; 1$ Ts. $2: 12 ; 2$ Ts. $1: 5 ; 2$ Ti. $4: 1,18$; He. $1: 8 ; 11: 33 ; 12: 28$. 
Esta diferencia de énfasis entre los evangelios y las epístolas de Pablo está en el evento del Calvario. Cristo crucificado es ahora el centro de la predicación del apóstol (1 Co. 1:23), el Cristo en quien se han cumplido las Escrituras (Gá. 4:4; 1 Co. 15:3), el Señor (Fil. 2:9-11). La comunidad posterior al Calvario no ha olvidado el reino de Dios, sino que lo ha discernido en forma nueva: el reino de Dios se ha hecho decisivamente eficaz en el señorío de Cristo ensalzado. En su señorío se anuncia ya el futuro consumado de Dios. Éste actúa en el señorío del Mesías por el don escatológico del perdón de los pecados (Ef. 1:7), en la comunicación del Espíritu a todo el que crea (Ro. 5:5; 2 Co. 13:14) y se bautice (Gá. 3:27). Elena de White, haciendo alusión a cómo debían cumplir su misión los apóstoles, destaca: "Los discípulos habían de realizar su obra en el nombre de Cristo". "El nombre Cristo, había de ser su consigna, su divisa distintiva, . . . la autoridad para su curso de acción. ... Nada que no llevara su nombre y su inscripción era digno de su nombre". ${ }^{1}$

Pablo discierne la eficacia y posible conocimiento del reino de Dios: "Porque el reino de Dios no consiste en palabras, sino en poder" (1 Co. 4:20); "porque el reino de Dios no es comida ni bebida, sino justicia, paz y gozo en el Espíritu Santo" (Ro. 14:17). Así que, no es de maravillarse que el apóstol hable expresamente del reino actual del Señor glorificado en el tiempo entre resurrección y regreso: el reino "Cristo lo entregará al Dios y Padre cuando haya suprimido todo dominio, toda autoridad y potencia" ( 1 Co. 15:24), pues él tiene que reinar, "hasta que haya puesto a todos sus enemigos debajo de sus pies" (1 Co. 15:25). "Y el postrer enemigo que

${ }^{1}$ Elena G. de White, Los hechos de los apóstoles (Mountain View, CA: Publicaciones Interamericanas, 1966), 23. 
será destruido es la muerte" ( 1 Co. 15:25; ver también Col 1:13; Ef.5:5; 2 Ts. 4:1, 18; He 1:8). Éste será el nuevo orden social, la nueva humanidad, completamente redimida, y éste será "todo en todos" (1 Co. 15:28).

Acerca del nuevo reino que Cristo le entregará a su Padre, Roberto Jamieson, A.R. Fausset y David Brown explican cuál será la posición del Jesús hombre en el nuevo orden: "Su coigualdad con el Padre es independiente de su oficio de intercesor, y anterior a él, y por tanto continuará cuando aquella función haya dejado de ser": Y respecto a su humanidad afirman: "La humanidad de Cristo también continuará eternamente, aunque será, como ahora, subordinada al Padre".

La iglesia es algo esencialmente presente y asumido en el futuro. El reino es algo que irrumpe en el presente, pero también algo decididamente futuro. La iglesia es una peregrinación por el intermedio escatológico, algo provisional; el reino es finalmente la gloria definitiva al cabo de todos los tiempos, una realidad postrera. La iglesia abarca pecadores y justos (Mt. 13:47-49), el reino es el reino de los justos y de los santos (Da. 7:27).

El libro de Apocalipsis contiene una amplia revelación sobre la iglesia desde su nacimiento hasta su final histórico. Haremos un breve examen de dicha revelación acerca del pueblo de Dios.

\footnotetext{
${ }^{1}$ Roberto Jamieson, A. R. Fausset y David Brown, Comentario exegético y explicativo de la Biblia, 2 vols., $3^{a}$ ed., trad. Jaime C. Quarles y Lemuel C. Quarles, José M. Rodríguez, Juan B. Garaño y Francisco Masias (Buenos Aires: Casa Bautista, 1967), 2:399.
} 
La iglesia en el Apocalipsis

En la isla de Patmos, en torno del año 96 d.C., Juan recibió "la revelación de Jesucristo" (Ap. 1:1). Juan ve inicialmente siete candeleros que simbolizan las siete iglesias de Asia, a las que deberá escribir cartas (Ap. 1:4, 13, 20). En la visión de Patmos, Cristo se presenta como el Hijo del Hombre entre los siete candeleros (Ap. $1: 13)$

\section{Cristo en el mensaje apocalíptico}

El Apocalipsis contiene el vocablo ekklēsia veinte veces. ' El reino está referido o relacionado con Cristo solamente cinco veces ${ }^{2}$ (Ap. 1:6,9; 5:10; 11:15; 12:10). Por su muerte y resurrección, Cristo pasó de predicador a ser predicado. Él es ahora el centro de la predicación de los seguidores suyos: el Mesías que murió ahora vive (Ap. 1:18) y es glorificado (Ap. 12:5; 1:13-15). El Cristo en quien se han cumplido las Escrituras puede ser comprendido por los que leen y escuchan la palabra de Dios (Ap. 1:3). A Jesús le han sido entregados la soberanía y el señorío (Ap. 1:5, 8). De ahí que la iglesia que surgió después de la muerte de Cristo no ha puesto en el olvido el reino de Dios, sino que lo ha comprendido de manera nueva por la revelación del Espíritu. ${ }^{3}$ El reino de Dios se ha hecho decisivamente efectivo en el señorío del Mesías ensalzado (Ap. 5:1-14). En su señorío se anuncia el futuro señorío

'Petter. ver "reino". Ap. 1:4, 11, 20; 2:1.7, 8, 11, 12, 17, 18, 23. 29; 3:1.6, 7, $13,14,22 ; 22: 16$.

${ }^{2}$ Petter, ver "iglesias". Ap. 1:6,9; 5:10; 11:15; 12:10.

${ }^{3}$ Ver Ap. 2:7, 11, 17, 29; 3:6, 13, 22. 
de Dios (Ap. 1:7). Éste actúa ya en el señorío de Cristo por el don escatológico del perdón de los pecados (Ap. 1:5), y en la comunicación del Espíritu a todos los que tienen la fe de Jesús (Ap. 14:12;13:10). De este modo la cristología del reino de Dios se encuentra presente en el Apocalipsis en relación con el señorío de Cristo.

\section{Cristo continúa guiando a su iglesia}

Cristo está guiando a su iglesia (Ap. 1:13). Él está presente mediante su Espíritu (Ap. 1:4; 4:5). El Señor no es sólo para la iglesia el suceso de un pasado que se va haciendo lejano, ni tampoco el acontecer de un futuro indefinido cercano o remoto. A él es a quien como Señor de todo están sometidos la humanidad entera y el mismo rumbo de la historia. Está atento a la marcha de la iglesia (Ap. 1:5, 8, 13). La iglesia no vive sólo de la obra de Cristo, acabada y completa (Ap. 5:6), ni tampoco solamente de la esperanza de la consumación futura de su obra (Ap. 1:7), sino de la presencia de Jesús operante. En armonía con esta idea, Clifford Goldstein explica que "la vida, la muerte y la resurrección de Cristo no terminaron su obra". Hace notar que "la mayoría de los cristianos que estudian cristología en el Apocalipsis investigan a Cristo como Cordero en su primera venida y como León en su segunda venida, o ambos; pero pierden de vista su papel decisivo intermedio entre uno y otro".2

Aquí Dios habla por su palabra con su iglesia (Ap. 1:3), y la iglesia con Dios

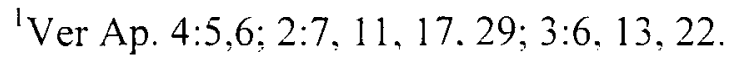

${ }^{2}$ Clifford Goldstein, Entre el cordero y el león (Bogotá: Asociación
} Publicadora Interamericana, 1995), 20. 
mediante la oración (Ap. 5:8; 8:3) y los cantos de alabanza (Ap. 14:2-3). Aquí se hace presente Cristo mediante su palabra que "sale de su boca como una espada aguda de dos filos" (Ap. 1:16); por su sacrificio (Ap. 5:6), y su resurrección (Ap.

1:18). De ahí el sometimiento con fe al oír el evangelio. 'George Eldon Ladd señala que "la palabra de Dios no es considerada en la Biblia meramente como un medio de comunicar la verdad, sino como una entidad activa, dinámica”.2

\section{Cristo y su iglesia}

La revelación apocalíptica muestra que entre Cristo y la iglesia no impera un algo capaz de vincular sólo éticamente a ambos, ni tampoco una polaridad en la que la iglesia y Cristo se comporten como sujeto y objeto. Entre Cristo y la iglesia existe unidad, en cuanto Cristo está intima y personalmente en la iglesia. Ésta es una verdad parcial. Cristo no se agota en la iglesia. Cuando la revelación apocalíptica habla de señorío y soberanía (Ap. 1:4, 5, 8; 9:16), no acentúa tanto este dominio sobre la iglesia $^{3}$. En el Apocalipsis no se recalca que la iglesia sean los súbditos que representan al soberano y todopoderoso Rey de reyes y Señor de señores (Ap. 1:5, 8; 19:16), sino que Cristo es el soberano y todopoderoso que sostiene con su diestra (Ap. 1:13,16,20), y da vida a su iglesia (v.18). Cristo es siempre el Señor de la iglesia. La revelación vital de Cristo y la iglesia incluye siempre contraposición

\footnotetext{
${ }^{\prime}$ Ver Ap. 1:9;6:9; 12:11; 17:6.
}

${ }^{2}$ George Eldon Ladd, El Apocalipsis de Juan: Un comentario, $3^{a}$ ed.. trad. Arnoldo Canclini (México, D.F.: Caribe, 1985), 24. 22:17.

${ }^{3}$ Ap. $14: 5 ; 12: 10-11 ; 6: 17 ; 7: 1-4 ; 14: 1 ; 15: 2 ; 17: 14 ; 18: 4 ; 19: 9 ; 20: 6 ; 21: 1-4,7 ;$ 
personal. De Cristo recibe la iglesia su vida (Ap. 11:11) y al mismo tiempo su promesa' e instrucción (Ap. 2:1, 8, 12, 18; 3:1, 7, 17).

Mervyn Maxwell admite la idea del Cristo soberano y todopoderoso que sostiene a su iglesia, viendo al trono de Dios como "el centro cósmico de control", y describiendo a "Dios en su trono y Jesús a su lado en un momento de tribulación para la iglesia". ${ }^{2}$ La iglesia está siempre ligada a Cristo como su norma: para Éfeso es "el que tiene las siete estrellas en su diestra, el que anda en medio de los siete candeleros de oro" (Ap. 2:1); para la iglesia de Esmirna es "el primero y el postrero, el que estuvo muerto y vivió" (v. 8); para la iglesia de Pérgamo es "el que tiene la espada aguda de dos filos" (v. 12); para la iglesia de Tiatira es "el Hijo de Dios, el que tiene ojos como de llama de fuego, y pies semejantes al bronce bruñido" (v. 18); para la iglesia de Sardis es "el que tiene los siete espíritus de Dios, y las siete estrellas" (Ap. 3:1); para la iglesia de Filadelfia es "el Santo, el Verdadero, el que tiene la llave de David, el que abre y ninguno cierra, y cierra y ninguno abre" (v. 7); y para la iglesia de Laodicea es "el Amén, el testigo fiel y verdadero, el principio de la creación de Dios" (v.14). Toda autonomía reside en la dependencia de la soberanía de su Rey (Ap. $1: 6 ; 5: 10 ; 20: 4$ ). La autonomía de la iglesia por la dependencia de la soberanía de Dios, es confirmada por Loron Wade cuando dice que "¡Dios está todavía en su trono; no ha perdido el mando del universo. Cristo triunfará!".

\footnotetext{
${ }^{1}$ Ap. $2: 7,11,17,26-29 ; 3: 5-6,12-13,21-22$.

${ }^{2}$ Mervyn Maxwell, El destino del planeta en rebelión, $2^{\mathrm{a}}$ ed., (Bogotá: Asociación Publicadora Interamericana, 1993), 152.
} 
Unido a este pensamiento expresa que "el objetivo primordial del Apocalipsis es el de inspirar confianza y seguridad en el corazón de la iglesia".'

La iglesia está constantemente remitida a Cristo, de él depende a cada instante de su existencia. Vive, pero no es ella la que vive, sino Cristo vive en ella (Ap. 1:13; 11:11). Sólo es fuerte en la fortaleza de Jesús. Sólo es libre en Aquel que libera del mal (Ap. 3:17-20). Acerca de la dependencia absoluta de la iglesia de su Señor, José Salguero piensa que Cristo, al presentarse como resucitado (Ap. 1:18), "reclama su poder sobre la vida", demanda su "derecho de gobierno sobre las iglesias" y requiere la facultad de ser "dueño de los destinos de esas mismas iglesias y del mundo entero". Argumenta que el derecho de gobernar "sobre las iglesias" y la autonomía de regir los destinos de esas mismas iglesias y del mundo "están expresados en el v. 19, cuando Cristo ordena a Juan a escribir para las siete iglesias tanto lo presente como lo que ha de suceder después". ${ }^{2}$

La iglesia de Apocalipsis se halla entre Cristo y su revelación apocalíptica en una relación de obediencia en la "fe de Jesús" (Ap. 14:12), de la que en ningún momento fue dispensada. No hay evolución histórica que pueda convertirla en relación de señorío en que la iglesia pueda disponer de Cristo y su palabra. La iglesia ha fracasado siempre que, por rodeos muy raros y encubiertos, ha querido apoderarse de Cristo y su palabra. Ha encontrado nueva vida siempre que ha roto toda

\footnotetext{
'Loron Wade, El futuro del mundo revelado en el Apocalipsis (Bogotá: Asociación Publicadora Interamericana, 1987), 77.

2"Yo soy el primero y el último [Ap. 1:18]", Biblia comentada. 9 vols. ed. Alberto Colunga (Madrid: Biblioteca de Autores Cristianos, 1960), 7:238.
} 
resistencia y ha vuelto de nuevo a Cristo, se ha sometido de nuevo a su palabra para hacerse de nuevo lo que realmente es: reyes y sacerdotes de su reino, bien y propiedad de Cristo. Tampoco la autoridad de la iglesia puede ser inmediata y originaria, sino siempre y únicamente derivada de Cristo y su palabra. Si la iglesia se somete humilde y modesta, reconociendo la autoridad de la palabra de Cristo, si no quiere oír predicar la propia sino la de Cristo, gana una autoridad que no puede darle el hombre. La iglesia debe ser siempre súbdita adoradora del Rey de reyes y Señor de señores (Ap. 19:16).

\section{Conclusión}

La iglesia es la asamblea de creyentes convocada por Dios. Surge exclusivamente por iniciativa divina. No se puede confundir la iglesia con el reino de Dios. El reino de Dios, la soberanía del creador, es supremo. La iglesia es un instrumento en las manos de Dios que coopera en la promoción de su reino. Después de la resurrección de Cristo se da comienzo a la iglesia cristiana; el Mesías deja de ser el predicador del "reino de Dios" para convertirse en el centro de la predicación de la iglesia. 


\section{CAPÍTULO IV}

\section{LA IGLESIA EN LOS ESCRITOS DE ELENA DE WHITE}

En este capitulo haremos una breve reseña histórica relativa a la vida y obra de Elena G. de White. Luego analizaremos su pensamiento en cuanto a la iglesia.

\section{Vida y obra de Elena G. de White}

Elena Gould Harmon nació en Gorham, Maine, Estados Unidos, el 26 de noviembre de 1827. A la edad de 8 años leyó que Jesús regresaría pronto a la tierra. Quedó profundamente impresionada al considerarse a sí misma indigna y sin preparación para enfrentarse a tal evento. En 1841 se bautizó en la Iglesia Metodista.

Guillermo Miller, al interpretar el texto de Daniel 8:14, llegó a la conclusión que Jesús vendría a la tierra alrededor de 1843 . Elena Harmon aceptó sus enseñanzas y se unió al movimiento adventista. En diciembre de 1844 recibió su primera visión. Escribió: "El poder de Dios descendió sobre mí como nunca hasta entonces". ${ }^{1}$ En agosto de 1846 contrajo matrimonio con Jaime White. ${ }^{2}$

${ }^{1}$ Elena G. de White, Notas biográficas de Elena G. de White (Buenos Aires:Casa Editora Sudamericana, 1981), 19.

${ }^{2}$ Departamento de Educación de la Asociación General de la Iglesia Adventista del Séptimo Día, La historia de nuestra iglesia (Buenos Aires: Casa Editora Sudamericana, 1963), 174. 
Elena de White escribió acerca de su llamado divino al ministerio profético: "Se me ha indicado que soy la mensajera del Señor". ${ }^{1}$ George R. Knight, al destacar la obra de Elena de White, dice que "su papel en la formulación de doctrinas fue más bien de confirmación que de iniciación". Explica Knight que "sus primeras visiones casi siempre confirmaban posiciones doctrinales a las que otros habían llegado mediante intenso y abarcante estudio de la Biblia".2

En armonía con Knight, el Centro White, que oficialmente custodia y publica los escritos de Elena de White, afirma que "las doctrinas sostenidas por los adventistas del séptimo día tienen su base en la Biblia. Fueron desarrollándose gradualmente por ferviente y piadoso estudio de la Palabra de Dios, por individuos y grupos". Específicamente señala que "en los primeros días del movimiento adventista, los zapadores [pioneros] permanecían a menudo juntos escudriñando las Escrituras para obtener luz y verdad hasta tarde en la noche". ${ }^{3}$ White confirma que "hubo estudio diligente y detallado de las Sagradas Escrituras. Se dedicaron noches casi integras a una investigación fervorosa de la Palabra". ${ }^{4}$ Ésta fue la base del sistema doctrinal de la Iglesia Adventista, que le ha dado su razón de ser.

${ }^{1}$ Elena G. de White, Mensajes selectos, 3 vols. (Mountain View, CA: Publicaciones Interamericanas, 1966), 1:36.

${ }^{2}$ George R. Knight, Conozcamos a Elena de White (Bögotá: Asociación Publicadora Interamericana, 2001), 23, 13-23.

${ }^{3}$ Departamento de Educación de lá División. Interamericana, La orientación profética en el movimiento adventista, trad. Cristina Samayoa (Miami: Departamento de Educación de la División Interamericana, 1964), 71.

${ }^{4}$ White, Mensajes selectos, 2:125. 
Según el Centro White, "los registros de la primera década de la historia adventista del séptimo día revelan las cuatro funciones del espíritu de profecía en el desarrollo de la doctrina". Los consejos de Elena G. de White ocupaban un lugar vital en "(1) iniciar y promover el estudio de la Biblia; (2) traer a la luz preciosas verdades bíblicas cuando los zapadores se confrontaban con verdades teológicas; (3) señalar errores que amenazaban la verdad bíblica; (4) confirmar conclusiones alcanzadas por ferviente estudio de las Escrituras". "Nunca las visiones constituyeron un sustituto para el estudio de la Biblia".

Elena de White, junto con "Hiram Edson, José Bates y Jaime White formaron el núcleo de nuestra iglesia". ${ }^{3}$ Knight afirma: "Sin duda alguna, Elena G. de White (1827-1915), ha sido la adventista del séptimo día de más influencia en la historia de la iglesia. Su presencia personal y sus escritos han sido trascendentales para conformar y guiar al adventismo durante sus siete décadas de ministerio profético". Y, agrega Knight: "Desde su muerte en 1915, sus consejos y percepciones siguen siendo iluminadores para la dirección de la iglesia cristiana". ${ }^{4}$ Sus escritos incluyen consideraciones acerca de la iglesia, que examinaremos a continuación.

\section{Elena G. de White y la iglesia}

Elena de White dice que la iglesia "es el medio señalado por Dios para la

${ }^{1}$ Departamento de Educación de la División Interamericana, 72.

${ }^{2}$ Ibíd.

${ }^{3}$ Departamento de Educación de la Asociación General, 156.

${ }^{4}$ Knight, Conozcamos a Elena de White, 8. 
salvación de los hombres, la depositaria de las riquezas de la gracia de Cristo". ${ }^{1}$ La iglesia milita en un mundo en rebelión, secuela de la rebelión de Lucifer, en el cielo. White explica que '"Lucifer, el 'portaluz', el que compartía la gloria de Dios, el ministro del trono, mediante la transgresión, se convirtió en Satanás el 'adversario' de Dios y de los seres santos". ${ }^{2}$ La iglesia "es la fortaleza de Dios, su ciudad de refugio, que él sostiene en un mundo en rebelión".3

Según White, la iglesia es "como una ciudad asentada sobre un monte", un testimonio visible del amor y el poder de Dios. Es "el escenario de su gracia, en el cual se deleita en revelar su poder para transformar los corazones". La iglesia "es el palacio de la vida santa".

Elena de White está hablando de la iglesia como una institución concreta. Para ella la iglesia de Jesucristo es la iglesia visible. "La iglesia es ahora militante". ${ }^{5}$

\section{La iglesia militante}

La percepción eclesiológica de Elena de White tenía fundamentalmente el propósito de mantener, contra conceptos espiritualistas, la forma visible de la iglesia,

'White, Los hechos de los apóstoles, 9.

${ }^{2}$ Elena G. de White, Patriarcas y profetas (Mountain View, CA: Publicaciones Interamericanas, 1955), 9.

${ }^{3}$ White, Los hechos de los apóstoles, 11.

${ }^{4}$ Ibíd.

${ }^{5}$ White, Joyas de los testimonios, 3:225. 
y el orden de la misma. Por ello pregunta: “¿No tiene Dios una iglesia viva?” Responde: "Él tiene una iglesia, pero es la iglesia militante, no la iglesia triunfante".

Para White no existe una iglesia ideal desligada de los seres humanos concretos, pecadores. Su argumento es que "la verdad es un poder santificador; pero la iglesia militante no es la iglesia triunfante. Hay cizaña entre el trigo". Los hombres continúan como miembros pecadores en la iglesia. "La iglesia de Cristo en la tierra será imperfecta, pero Dios no destruye a su iglesia a causa de su imperfección”. Por lo tanto, “el Señor no autoriza a sacar la conclusión de que la iglesia es perfecta". ${ }^{2}$ Sólo la incredulidad separa de Cristo y de la iglesia. White explica que el miembro de iglesia que peca contra alguien y luego no escucha al ofendido, ni a los testigos ni al cuerpo de creyentes, "ha roto el vínculo que lo une con Cristo y así se ha separado de la comunión de la iglesia". ${ }^{3}$ El miembro de la iglesia que a pesar de su falla continúa creyendo, no pierde el vínculo con Cristo, ni la comunión con la iglesia, de acuerdo con Mt. 18:15.

Aunque "la iglesia militante" no es "la iglesia triunfante", durante toda su existencia debiera ser el signo visible de la salvación eterna. White admite que "en

'Elena G. de White, Testimonios para los ministros (Buenos Aires: Casa Editora Sudamericana, 1977), 45.

${ }^{2}$ Ibíd., 61, 46, 47.

${ }^{3}$ Elena G. de White White, El Deseado de todas las gentes (Buenos Aires: Casa Editora Sudamericana, 1976), 408. 
verdad el Espíritu Santo ha salido a todo el mundo; por todas partes obra en los corazones de los hombres; pero es en la iglesia donde hemos de crecer y madurar para el alfolí de Dios".

Si "la iglesia militante" no es "la iglesia triunfante", la iglesia está esencialmente entre los tiempos; es iglesia de transición; va en busca de la consumación del mundo por Dios. La iglesia "militante" es la iglesia real de Jesucristo. Es imposible verla como aislada de todo lo terreno, exenta de todo error y de todo pecado. Los seres humanos no tienen que aferrarse a la iglesia, sino a Cristo mismo. Elena de White combate la idea y la actitud de dependencia salvífica de la iglesia, y su advertencia es: "Aquellos que se han unido a la iglesia, pero no se han unido a Cristo serán manifestados". ${ }^{2}$ Indica: "El hecho de que los hombres se hallen en el seno de la iglesia no prueba que sean cristianos". ${ }^{3}$ No obstante, White sostiene que "la iglesia es la fortaleza de Dios. . . . Cualquier traición a la iglesia es traición hecha a Aquel que ha comprado a la humanidad con la sangre de su hijo unigénito. Desde el principio, las almas fieles han constituido la iglesia en la tierra". ${ }^{4}$ Debido a que ningún ser humano está en condiciones de determinar quiénes son los fieles en la iglesia se infiere que estas "almas fieles" representan la iglesia invisible.

${ }^{1}$ Elena G. de White, Palabras de vida del gran maestro (Mountain View, CA: Publicaciones Interamericanas, 1971), 49.

${ }^{2}$ Ibíd., 52.

${ }^{3}$ Ibíd.

${ }^{4}$ White, Los hechos de los apóstoles, 10. 


\section{La iglesia invisible}

La iglesia invisible es sólo un concepto espiritual. Sólo Dios puede determinar quiénes son "las almas fieles". White hace notar que "el hombre juzga por la apariencia, pero Dios juzga el corazón". Por esta razón, "la cizaña y el trigo han de crecer juntamente hasta la cosecha; y la cosecha es el fin del tiempo de gracia". La iglesia invisible simplemente expresa su unión y relación con Cristo. El concepto de iglesia invisible no tiene una expresión concreta en forma objetiva. De ahí que White afirme que "si tratásemos de extirpar de la iglesia a aquellos que suponemos cristianos falsos, cometeríamos errores. A menudo consideramos sin esperanza a los mismos a quienes Cristo está atrayendo hacia sí. Si tuviésemos que tratar estas almas de acuerdo con nuestro juicio imperfecto, tal vez ello extinguiría su última esperanza". Asegura que "en el cielo habrá muchos de quienes sus prójimos suponian que nunca estarían alli’. ${ }^{2}$

En la iglesia y en la acción de la iglesia obra Dios; pero la manera como actúa Dios y como actúa la iglesia no son idénticas. La iglesia invisible es la congregación de los creyentes y obedientes. Es una comunidad de personas que buscan, peregrinan y yerran, que están enteramente remitidas a la gracia y verdad de Dios, a su perdón y liberación, y ponen su confianza en Dios. ${ }^{3}$

La iglesia absolutamente invisible no ha existido nunca ni existirá en esta

\footnotetext{
${ }^{1}$ White, Palabras de vida del gran maestro, 50.

${ }^{2}$ Ibíd.; 50.

${ }^{3}$ Ver Mt. 13:27-29; Lc. 15:25-30; 18:9-14; Hch. 2:47.
} 
tierra. El trigo y la cizaña estarán mezclados en la iglesia hasta el fin del mundo.

Elena de White advierte: "Se permite que la cizaña crezca entre el trigo, que tenga todas las ventajas del sol y de la lluvia, pero en el tiempo de la siega, 'os tornaréis, y echaréis de ver la diferencia entre el justo y el malo, entre el que sirve a Dios y el que no lo sirve' (Mal. 3:18)". Agrega a esta advertencia la aclaración: "El Salvador no señala un tiempo en que toda la cizaña se convertirá en trigo. El trigo y la cizaña crecen juntamente hasta el tiempo de la cosecha, el fin del mundo".

Sólo una doctrina de la iglesia abstracta e idealista, que no describa a la iglesia real, sino que forje otra ideal, podría cerrar los ojos a lo defectuoso y negativo de la iglesia. Según White, “algunas personas parecen pensar que al entrar en la iglesia serán cumplidas sus expectativas, y hallarán solamente personas puras y perfectas". ${ }^{2}$ Al creyente celoso de su fe puede resultarle molesto que en la iglesia haya personas imperfectas. Cuando ven faltas en los miembros de la iglesia dicen: "Nosotros abandonamos el mundo para no tener ninguna asociación con individuos malos, pero el mal se halla aquí también". 3 Pero el cristiano fiel aceptará este hecho, sabiendo que la iglesia, como comunidad de seres humanos que sirve a seres humanos, debe ser visible para poder cumplir con su misión. Cada cristiano individual, como también la congregación de los creyentes, tiene que existir en el tiempo y en el espacio, a fin de prestar al mundo el servicio que se espera de ellas. De ahí que Elena

\footnotetext{
${ }^{1}$ White, Palabras de vida del gran maestro, 53.

${ }^{2}$ White, Testimonios para los ministros, 47.

${ }^{3}$ Ibíd.
} 
de White afirme que la iglesia "fue organizada para servir y su misión es la de anunciar el Evangelio al mundo". ${ }^{1}$

No es que existan dos iglesias, una visible y otra invisible. Tampoco se puede aseverar que la iglesia visible es una copia de la iglesia verdadera que sería la invisible. No puede tomarse lo invisible como lo esencial y lo visible como simplemente una forma de iglesia. La iglesia es una sola, al mismo tiempo visible e invisible. White afima que Cristo "dirige a los pecadores a la iglesia, que él ha puesto como medio de comunicar luz al mundo".2 Agrega que "en el mundo existe solamente una iglesia que está actualmente en la brecha, reparando el muro, reedificando las ruinas". La caracteriza como "un pueblo distinto, una iglesia en la tierra, que no es inferior a otro alguno, sino superior a todos en su capacidad de enseñar la verdad y vindicar la ley de Dios". 3

La iglesia visible permanece en medio de los cambios históricos, a pesar de sus defectos. Elena de White sostiene que "aunque existen males en la iglesia, y los habrá hasta el fin del mundo, la iglesia ha de ser en estos postreros días, luz para un mundo que está contaminado y corrompido por el pecado". 4

\footnotetext{
${ }^{1}$ White, Los hechos de los apóstoles, 9.

${ }^{2}$ Ibíd.; 100.

${ }^{3}$ White, Testimonios para los ministros, 50, 58.

${ }^{4}$ Ibíd., 49.
} 
Y explica: "Lo que Dios quiso hacer a favor del mundo por medio de Israel, la nación escogida, lo realizará finalmente mediante su iglesia que está en la tierra hoy". ${ }^{1} \mathrm{La}$ iglesia remanente.

\section{La iglesia y el remanente}

"Remanente" en el lenguaje del Antiguo Testamento señalaba a los "israelitas que sobrevivieron a calamidades como guerra, cautiverio, pestilencia y hambre, pero que fueron salvados por misericordia para seguir siendo el pueblo escogido de Dios (Gn. 45:7; Esd. 9:13; Ez. 7:16)".2

Al fracasar Israel como pueblo escogido, por rechazar al Mesías, sobrevivió un remanente, un grupo de judíos fieles que por misericordia de Dios pasaron a fundar la iglesia de Cristo, no como judíos, sino como cristianos. Elena de White explica: “A pesar del fracaso de Israel como nación, había entre ellos un buen remanente que se salvaría. ... Cuando se fundó la iglesia cristiana primitiva, estaba compuesta de estos fieles judíos que reconocieron a Jesús de Nazaret como Aquel cuyo advenimiento habían anhelado". 3

Luego, según White, "por su alejamiento del Señor, su alianza con los paganos, la iglesia judia se transformó en ramera; Roma se corrompió de igual manera al buscar apoyo de los poderes mundanos y por consiguiente recibe la misma

\footnotetext{
${ }^{1}$ Ibíd.

${ }^{2} C B A, 7: 827$.

${ }^{3}$ White, Los hechos de los apóstoles, 302.
} 
condenación".' Durante largos siglos vivió la iglesia prácticamente de espaldas a su Señor. La iglesia, que con la ayuda del poder civil oprimía y perseguía a los cristianos fieles a la revelación bíblica, era la más convencida de que ella era el pueblo remanente, la sucesora, representante y heredera del Israel. A partir del siglo XVI, con la Reforma protestante, Dios levantó otro remanente que continuaria sosteniendo las verdades de la Biblia. ${ }^{2}$

\section{El remanente a partir del siglo XVI}

Según Elena de White, “Roma le negó la Biblia al pueblo y exigió en su lugar que todos aceptasen sus propias enseñanzas. La Reforma consistió en devolver a los hombres la Palabra de Dios". 3 Y de este modo surgieron las iglesias protestantes. “Al nacer, esas iglesias se decidieron noblemente por Dios y la verdad, y la bendición divina las acompañó. Aun el mundo incrédulo se vio obligado a reconocer los felices resultados de la aceptación de los principios del evangelio". ${ }^{4}$ La iglesia remanente había hallado nueva vida. A estas iglesias protestantes, afirma Elena de White, "se les aplican las palabras del profeta Ezequiel a Israel: 'Salió tu renombre entre las naciones, en atención a tu hermosura, la cual era perfecta, a causa de mis adornos, que yo había puesto sobre ti', dice Jehová el Señor”. Pero “estas iglesias

${ }^{1}$ Elena G. de White, El conflicto de los siglos (Bogotá: Asociación Publicadora Interamericana, 1954), 433.

2Ibíd., 53-65.

${ }^{3}$ Ibid., 439.

${ }^{4}$ Ibid., 433. 
cayeron víctimas del mismo deseo que causó la maldición y la ruina de Israel: el deseo de imitar la práctica de los impíos y de buscar su amistad. 'Pusiste la confianza en tu hermosura y te prostituiste a causa de tu renombre'. (Ez. 16:14,15, V.M.)".'

¿Cómo ocurrió esto? White explica que "al rechazar la amonestación del primer ángel, ${ }^{2}$ rechazaron los medios que Dios había provisto para su redención. .., y con mayor ardor volvieron a buscar la amistad del mundo". White hace notar que "tal era la causa del terrible estado de mundanalidad, apostasia y muerte espiritual que imperaba en las iglesias en $1844 "{ }^{3}$

El mensaje del primer ángel es seguido por otro que anuncia: "Caida, caída es la gran Babilonia" (Ap 14:8). ${ }^{4}$ Según White, “el mensaje de Ap. 14, que anuncia la caída de Babilonia, debe aplicarse a comunidades religiosas que en un tiempo fueron puras y luego se han corrompido... . No puede por consiguiente referirse sólo a la iglesia romana, pues dicha iglesia está en condición caída desde hace muchos siglos". ${ }^{1}$ Luego señala: "El mensaje del segundo ángel de Apocalipsis 14 fue proclamado por primera vez en el verano de 1844 , y se aplicaba entonces más particularmente a las iglesias de los Estados Unidos de Norteamérica". Y da como razón que, alli fue "donde la amonestación del juicio había sido también más

${ }^{1}$ Ibíd., 433-437.

${ }^{2}$ Referencia a Ap. 14:6-7 que, según la Iglesia Adventista, comenzó a ser proclamado en el surgimiento del movimiento adventista del siglo XIX. Véase White, El conflicto de los siglos, 429.

${ }^{3}$ Ibíd., 431.

${ }^{4}$ Ibíd., 433. 
razón que, allí fue "donde la amonestación del juicio había sido también más ampliamente proclamada y más generalmente rechazada, y donde el decaimiento de la iglesias había sido más rápido". " De este modo se da lugar a un nuevo remanente.

\section{El remanente del tiempo del fin}

Según Elena de White, "al predicar la doctrina del segundo advenimiento, Guillermo Miller y sus colaboradores no tuvieron otro propósito que el de estimular a los hombres para que se preparasen para el juicio". Pero los ministros y otros líderes de las iglesias reaccionaron "contra la doctrina del advenimiento y quisieron sofocar el nuevo movimiento". La amenaza exterior fue tan manifiesta que les "negaron a sus miembros el derecho a asistir a predicaciones" sobre el advenimiento de Jesús, “y hasta de hablar de sus esperanzas en las reuniones de edificación mutua en la iglesia". Frente a esta opresión espiritual, White afirma que "en el verano de 1844 cerca de cincuenta mil personas se separaron de las iglesias".2

De esta manera, en dramática historia profética, el movimiento adventista millerista preparó el terreno para el surgimiento de un nuevo remanente. El chasco del 22 de octubre de 1844 consolidó un pequeño remanente en torno de una nueva comprensión de la profecía de Dn. 8:14. Según White, "los que andaban en la luz de la palabra profética vieron que en lugar de venir a la tierra al fin de los 2300 días proféticos en 1844, Cristo entró entonces en el lugar santísimo del santuario celestial para cumplir la expiación preparatoria para su venida". Y agregó: "El asunto del

\footnotetext{
${ }^{1}$ Ibíd., 440.

${ }^{2}$ Ibíd., 425, 426.
} 
santuario fue la clave que aclaró el misterio del desengaño de 1844. Reveló todo el sistema de verdades que formaban un conjunto armonioso y demostraban que la mano de Dios había dirigido el gran movimiento adventista, y al poner de manifiesto la situación y la obra de su pueblo, le indicaba cuál era su deber de alli en adelante". El pequeño remanente, unido en torno de una nueva visión de la obra de Cristo en el santuario celestial, demoró hasta 1860 para escoger el nombre adventista del séptimo día. En este contexto, White explica: "Recibí una revelación acerca de la adopción de un nombre para el pueblo remanente". Y agrega: "No podíamos elegir un nombre más apropiado que el que concuerda con nuestra profesión, expresa nuestra fe y nos señala como un pueblo peculiar". ${ }^{2}$ Según White, "El nombre Adventista del Séptimo Día presenta los verdaderos rasgos de nuestra fe, y convencerá la mente inquisidora como una saeta del carcaj del Señor, herirá a los transgresores de la ley de Dios, e inducirá al arrepentimiento para con Dios y a la fe en nuestro Señor Jesucristo". ${ }^{3}$ Destaca White que "el nombre de adventista del séptimo día es una permanente represión para el mundo protestante". Implica adorar a Dios y obedecer sus mandamientos. White hace notar que en este nombre, se "halla la línea de demarcación entre los que adoran a Dios y los que adoran la bestia y reciben su marca". ${ }^{4}$

\footnotetext{
${ }^{1}$ Ibid., 474, 475, 476.

${ }^{2}$ White, Joyas de los testimonios, 1:81.

${ }^{3}$ Ibíd.

${ }^{4}$ Ibíd., 1:80.
} 
La estrecha unión de Dios y su iglesia se basa en la libre elección, gracia, amor y fidelidad de Dios. La iglesia, "aunque débil y defectuosa, constituye el único objeto de la tierra, al cual Cristo otorga su consideración suprema". '

Lo que la iglesia no es por naturaleza, Dios se lo concede por gracia porque, según White, "no hay en este mundo nada que sea tan caro para Dios como su iglesia. $^{2}$ No hay nada que ofenda tanto a Dios como los esfuerzos realizados por los siervos de Satanás para robarle a su pueblo sus derechos. El Señor no ha olvidado a sus hijos". ${ }^{3}$

\section{El remanente y la crisis final}

Elena de White, escribiendo acerca del tiempo de angustia después que termine el tiempo de gracia, anticipó: "El pueblo de Dios se verá entonces sumido en las escenas de aflicción y angustia descritas por el profeta y llamadas el tiempo de apretura de Jacob" ${ }^{4}$. La resistencia del remanente a claudicar ante el mundo lo conducirá a un período de angustia sin precedentes. Según White, "su aflicción es grande, las llamas del horno parecen estar a punto de consumirlos; pero el Refinador los sacará como oro purificado por el fuego.... Las lecciones de fe que hayan descuidado, tendrán que aprenderlas bajo el terrible peso del desaliento". White hace notar: "Necesitan pasar por el horno de fuego; debe consumirse su mundanalidad,

\footnotetext{
${ }^{1}$ White, Mensajes selectos, 2:457.

${ }^{2}$ White, Joyas de los testimonios, 2:381.

${ }^{3}$ Ibid., $2: 458$.

${ }^{4}$ White, El conflicto de los siglos, 673.
} 
para que la imagen de Cristo se refleje perfectamente". ${ }^{1}$ Por otra parte asegura ella: “cuando el carácter de Cristo sea perfectamente reproducido en su pueblo, vendrá a reclamarlo como suyo". ${ }^{2}$ Por ello White aclara que en el tiempo presente Dios "tiene una iglesia, pero es la iglesia militante, no la iglesia triunfante. ${ }^{3}$ Y luego argumenta: “Todo nuestro celo no permitirá tener éxito en lograr que la iglesia militante sea tan pura como la triunfante". ${ }^{4}$

\section{Conclusión}

La iglesia de Cristo, según los escritos de Elena G. de White, "es la depositaria de las riquezas de la gracia de Cristo". Ella constituye "la fortaleza de Dios, su ciudad de refugio que él sostiene en un mundo en rebelión". Es considerada "el escenario de su gracia, en el cual se deleita en revelar su poder para transformar los corazones.

La iglesia cristiana, desde su mismo comienzo, es el remanente que ha sobrevivido por su fidelidad en cada época y que sobrevivirá hasta el fin del tiempo. Este remanente necesita ser evaluado frente a las acusaciones del grupo Koinonía. ${ }^{5}$

\footnotetext{
${ }^{1}$ Ibíd., 679.

${ }^{2}$ White, Palabras de vida del gran maestro, 47.

${ }^{3}$ White, Testimonios para los ministros, 45.

${ }^{4}$ Ibíd., 47.

${ }^{5}$ Ver también el apéndice, con citas adicionales de los escritos de Elena G. de White que complementan el contenido de éste capítulo.
} 


\section{CAPÍTULO V}

\section{ASPECTOS PECULIARES DE LA ECLESIOLOGÍA DEL MOVIMIENTO KOINONÍA}

Con ayuda de la Biblia y de los escritos de Elena G. de White haremos una evaluación de algunos aspectos propios de la eclesiología del movimiento disidente. Éstos son: la Iglesia Adventista en apostasía, la organización de la iglesia, y el uso del diezmo.

\section{La Iglesia Adventista en apostasía}

Según Elena de White, "han ocurrido apostasías y el Señor ha permitido que asuntos de esa naturaleza se desarrollen en el pasado a fin de mostrar con cuánta facilidad sus hijos serán descarriados, cuando dependan de las palabras de los hombres en vez de investigar por sí mismos las Escrituras, como lo hicieron los nobles bereanos, para ver si esas cosas eran asi'."

También en el futuro, escribe White: "tendremos apostasías, las esperamos". ${ }^{2}$ Es preciso definir qué es la apostasía.

\footnotetext{
${ }^{1}$ White, Mensajes selectos, 2:454.

${ }^{2}$ Ibíd., 3:486.
} 
Definiciones de apostasía

\section{Según Koinonía}

El grupo Koinonía considera como indicación de apostasía de la Iglesia Adventista el que algunos líderes rechazaron el mensaje de la justificación por la fe en el Congreso de la Asociación General en Minneápolis, Minnesotá, celebrado del 17 de octubre al 4 de noviembre de 1888 . Desde entonces no hay posibilidad de ver con luz positiva la historia de la Iglesia Adventista. Debe finalmente ser estimada como renuncia al evangelio, como caída en el institucionalismo y el clericalismo. ${ }^{1}$

Koinonía considera también como indicadores de apostasía de la iglesia el uso de productos animales en la dieta, el uso de la medicina alópata y el vivir en las ciudades. ${ }^{2}$ Según Koinonía, la apostasía de la iglesia está expresada en el pecado que se observa en algunos miembros. ${ }^{3}$

Finalmente, la apostasía de la iglesia está en la estructura, desde la Asociación General para abajo, en todo su liderazgo, pero no en la iglesia en sí. La iglesia y la organización son dos cosas diferentes. La evidencia de ello fue que Cristo perteneció al pueblo de Dios pero no se sometió a su organización. De ahí que Koinonía pertenece a la iglesia pero no a su organización. ${ }^{4}$

\footnotetext{
${ }^{1}$ Hennessey, entrevista.

${ }^{2}$ Ibíd.

${ }^{3}$ Hernández, entrevista.

${ }^{4}$ Navarro, entrevista.
} 


\section{Según la Biblia}

En el Antiguo Testamento, los vocablos hebreos marad (rebelarse) y mered (rebelión) han sido traducidos por apostasía. ${ }^{1}$ Los autores de la versión griega del Antiguo Testamento (Septuaginta), adoptaron el término para expresar el apartamiento o la rebelión contra Dios (ver Jos. 22:22): ${ }^{2}$

“Apostasía" es una palabra griega que consta de dos partes: la preposición apo que como adverbio significa "aparte", "lejos", ${ }^{3}$ y stasis, que significa “discusión”, "altercado", "controversia"; "rebelión", "revuelta", "alboroto"; "duración", "existencia". Se usaba para identificar una insurrección política o militar. ${ }^{4}$

El Nuevo Testamento sólo contiene dos textos (Hch. 21:21;2 Ts. 2:3) donde se encuentra la palabra "apostasía". Para los escritores del Nuevo Testamento, apostasía significaba apartarse de la fe cristiana, alejándose así de la comunidad de los creyentes para adoptar otras ideas y prácticas. Ésta es la idea que Lucas trata de expresar al registrar que había una acusación contra Pablo de enseñar “a todos los judios que están entre los gentiles a apostatar de Moisés, diciéndoles que no circunciden a sus hijos, ni observen las costumbres" (Hch. 21:21). “Apostatar de Moisés" equivalía a abandonar sus enseñanzas. Pablo, en 2 Ts. 2:3, 4, 10 anticipó en su tiempo la aparición de la apostasía y la manifestación del "hijo de pecado" que se opondría a Dios usurpando su lugar en el templo, y que su venida sería por

\footnotetext{
${ }^{1} D B I$, ver "apostasía".

${ }^{2}$ Ibid.

${ }^{3}$ Diccionario conciso griego-español del Nuevo Testamento, ed. 1978, ver "stasis".

${ }^{4}$ Nuevo diccionario de la Biblia, ed. 1999, ver "apostasía".
} 
obra de Satanás que obraría "con todo engaño de iniquidad para los que se pierden, por cuanto no recibieron el amor de la verdad para ser salvos".

Cerca del fin de su vida, Pablo reitera su advertencia sobre espíritus engañadores que, en los postreros tiempos, llevarán a algunos hasta apostatar de la fe mediante la predicación de doctrinas de demonios (1 Ti. 4:1). Juan, el apóstol, considerando los "muchos anticristos" surgidos ya en sus días, comenta: "Salieron de nosotros pero no eran de nosotros; porque si hubiesen sido de nosotros, habrían permanecido con nosotros; pero salieron para que se manifestase que no todos son de nosotros" (1 Jn. 2:18-19).

Si la apostasía es el acto de rechazar la fe cristiana o las doctrinas reveladas, apartándose para adoptar otras, las enseñanzas que se oponen a la verdad bíblica son plantas no sembradas por el Padre celestial. Esto fue lo que Jesús expresó al confrontar a los escribas y fariseos. Los acusó diciendo que invalidaban la palabra de Dios con sus tradiciones: "Dejando el mandamiento de Dios, os aferráis a la tradición de los hombres" (Mr. 7:8, 13). Jesús advirtió: "Toda planta que no plantó mi Padre celestial, será desarraigada" (Mt. 15:13). Así predijo la destrucción definitiva de toda falsa enseñanza.

\section{Según Elena G. de White}

Elena de White escribió: “La rebelión y la apostasia están en el aire mismo que respiramos". Y agrega: “Los que apostatan están dando expresión a las palabras del dragón. ... Los que apostatan dejan el pueblo de Dios, fiel y verdadero, y confraternizan con los que representan a Barrabás". 1

Precisamente aquí se plantea la cuestión de los criterios por los que puede distinguirse entre falsa y verdadera iglesia, entre la apostasía de la iglesia y la apostasía

\footnotetext{
${ }^{1}$ White, Mensajes selectos, 2:455.
} 
en la iglesia. En primera instancia, para definir estos criterios examinaremos brevemente la crisis que sacudió a la Iglesia Adventista en el congreso de Minneápolis de 1888. Esta crisis se ha convertido en fundamento de Koinonía y otros para declarar a la iglesia en apostasía.

\section{Apostasía en Minneápolis en 1888}

El congreso de la Asociación General en Minneápolis, Minnesota, fue celebrado desde el 17 de octubre hasta el 4 de noviembre de 1888. En estas reuniones, los pastores Alonso Trevier Jones y Ellet Joseph Waggoner expusieron el mensaje de justificación por la fe ${ }^{1}$, y recibieron el siguiente respaldo de Elena de White: "El Señor en su gran misericordia envió un preciosísimo mensaje a su pueblo por medio de los pastores Waggoner y Jones". 2

Este mensaje de la justificación por la fe fue inicialmente rechazado por George Butler, presidente de la Asociación General, por Urías Smith, A. T. Morrison y otros. ${ }^{3}$ Elena de White comenta: "La falta de voluntad para renunciar a opiniones preconcebidas y aceptar esta verdad fue la principal base de la oposición manifestada en Minneápolis contra el mensaje del Señor expuesto por los hermanos [E. J.] y Waggoner y [A. T.] Jones". ${ }^{4}$ Este rechazo por un grupo de líderes fue motivo para que algunos críticos declarasen que la Iglesia Adventista había sido rechazada por Dios, y así había

${ }^{1}$ White, Testimonios para los ministros, xxiii.

${ }^{2}$ Ibíd., 91.

${ }^{3}$ Arnoldo Valentin Wallenkampf. Lo que todo adventista deberia saber sobre 1888, trad. Rolando A. Itin (Buenos Aires: Asociación Casa Editora Sudamericana, 1989), 30-35.

${ }^{4}$ White, Mensajes selectos, 1:276. 
apostatado. El grupo Koinonia ha hecho suya esta opinión.

Pocos años después del congreso de Minneápolis de 1888, el 23 de diciembre de 1892, White escribió: "Queridos hermanos de la Asociación General: testifico ante mis hermanos y hermanas que la iglesia de Cristo, por débil y defectuosa que sea, es el único objeto en la tierra al cual él concede su suprema consideración". ${ }^{1}$ Casi 25 años después de Minneápolis, en uno de sus últimos mensajes dirigidos a la Asociación General (4 de mayo de 1913), White escribió: "Me siento animada y bendecida al comprender que el Dios de Israel sigue conduciendo a su pueblo y que continuará con él hasta el fin".2

Es sorprendente que para el grupo Koinonía la Iglesia Adventista haya quedado en apostasía porque algunos rechazaron el mensaje de justificación por la fe en el congreso de Minneápolis de 1888, mientras que Elena de White, veinticinco años después aseguraba que Dios seguía conduciendo a su iglesia y la conduciría hasta el fin.

Por otra parte, Elena de White hace la denuncia que "algunos miembros de la iglesia tienen orgullo, suficiencia propia e incredulidad arraigada y manifiestan resistencia a abandonar sus ideas, aunque se amontonen evidencias que indican que el mensaje de Laodicea se aplica a ellos". ${ }^{3}$ La iglesia como congregación está constituida por seres humanos, y ello quiere decir que son pecadores que buscan, peregrinan y yerran. La iglesia necesita el reproche y el consejo divino.

\footnotetext{
${ }^{\cdot}$ White, Testimonios para los ministros, 15.

${ }^{2}$ White, Mensajes selectos, 2:470.

${ }^{3}$ Ibíd., 2:78.
} 
Apostasía e iglesia verdadera

En sus enseñanzas, el grupo Koinonía toma la reprobación del mal que existe en la iglesia como evidencia de que Dios la ha rechazado. Elena de White admite que el "Señor reprueba el mal que hay en su pueblo”, y pregunta: “¿Pero constituye esto una evidencia de que él lo ha rechazado?” Su respuesta es: “No. En la iglesia hay errores y el Señor los señala mediante instrumentos que él mismo ha instituido". Luego, lanza una nueva pregunta "¿Tomaremos por eso estos reproches y los aprovecharemos para decir que Dios no está impartiendo a su pueblo su luz y su amor?" A lo que responde: 'No. La obra que el Señor está procurando realizar por su pueblo demuestra que lo ama y que desea alejarlo de las sendas peligrosas". ${ }^{1}$

La iglesia militante no es toda ella el pueblo de Dios. Junto a los miembros fieles, puede haber infieles. De uno u otro modo, es una congregación mixta, una mezcla de trigo y cizaña (Mt. 13:24-30, 36-43), de buenos y malos peces (Mt. 13:47-49), de "ovejas" y "cabritos" (Mt. 25:31-33).

¿Qué quiere decir que la Iglesia Adventista del Séptimo Día sea parte del pueblo de Dios? Elena de White, hablando del fundamento que le daba la verdadera identidad a Israel como pueblo de Dios, explica: “A este pueblo le fueron confiados los oráculos de Dios. Se los rodeó con el vallado de los preceptos de su ley, los principios eternos de la verdad, justicia y pureza". ${ }^{2}$ Por otra parte, respondiendo a una acusación que se le hacía a la Iglesia Adventista de ser Babilonia, dijo: "Cómo se regocijaría Satanás si pudiera conseguir que se proclamase un mensaje según el cual el único pueblo a quien Dios ha

\footnotetext{
${ }^{1}$ Ibíd., 2:93.

${ }^{2}$ White, Palabras de vida del gran maestro, 230.
} 
hecho depositario de su ley sea aquel a quien se aplica ese mensaje". ' No es la apostasía de algunos miembros de la comunidad de creyentes la que produce la apostasía del pueblo de Dios, sino el rechazo oficial de la verdad que Dios ha depositado en él. ${ }^{2}$

Otro caso de apostasía que tiene importancia, para la definición de criterios en cuanto a la apostasía de la iglesia y la apostasía en la iglesia, es la crisis que generó John Harvey Kellogg, médico adventista de renombre en el tiempo de White.

\section{Apostasía alfa y omega}

El 24 de julio de 1904 Elena de White se refirió a la apostasía de John Harvey Kellogg, y la gran controversia desatada por ello dentro de la Iglesia Adventista del Séptimo Día, diciendo que ésta era "el alfa de las herejías mortíferas". 3

Elena de White no universalizó la apostasía de Kellogg. Al hacer la advertencia respecto a la apostasía omega tampoco habló de toda la iglesia, sino que observó: "La omega seguirá y será recibida por los que no estén dispuestos a prestar atención a la amonestación que Dios ha dado". ${ }^{4}$ Simultáneamente, usó el alfa y la omega para hacer la siguiente advertencia: "No os engañéis, muchos se apartarán de la fe prestando atención a espíritus engañadores y doctrinas de demonios. Tenemos delante de nosotros el alfa de este peligro. La omega será de una naturaleza asombrosísima".5

\footnotetext{
${ }^{1}$ White, Mensajes selectos, 2:77.
}

${ }^{2}$ Ver Mt. 26:3, 5, 57-68; Jn. 18:36-19:16; véase White, "Sanedrín" El Deseado de todas las gentes, 105-106; "La Asociación General" Obreros evangélicos, 505-506.

${ }^{3}$ White, Mensajes selectos, 1:226, 233.

${ }^{4}$ Ibíd., 1:233.

${ }^{5}$ Ibid., 1:231. 
En estas citas hay que precisar si Elena de White está hablando de la apostasía de la iglesia o de la apostasía en la iglesia. Hay que tomar en cuenta las frases "aquellos que no están plenamente establecidos", "los que no están dispuestos", "muchos se apartarán". Estas frases particularizantes y no globalizantes no autorizan a sacar la conclusión de que la apostasía omega es una apostasía de la iglesia, sino una apostasía en la iglesia. No es la iglesia en su totalidad la que será engañada, sino miembros en particular que prestarán "atención a espiritus engañadores y a doctrinas de demonios".

En el contexto de la apostasía alfa, Elena de White, sabiendo que "la omega" seguiría, escribió: "El enemigo ... introducirá todo lo que pueda para llevar a cabo designios engañosos. Pero el Señor hará surgir hombres de percepción aguda en el plan de Dios". Las verdades a las que hace referencia son "los principios de la verdad que nos ha revelado Dios". ${ }^{2}$ El tiempo transcurrido no ha disminuido su valor". ${ }^{3}$

\section{Dios trabaja por medio de la iglesia}

Elena de White afirma que "Dios ha constituido a su iglesia en la tierra en un canal de luz y por su medio comunica sus propósitos y su voluntad". ${ }^{4}$ En defensa de quienes llevaban la responsabilidad de la obra, advirtió: “El que cualquier obrero de la causa de Dios pase por alto a los tales y piense que la luz divina no puede venir por ningún otro medio que directamente de Dios se coloca en una posición donde está expuesto a ser

\footnotetext{
${ }^{1}$ Ibíd.

${ }^{2}$ Ibíd., 1:235.

${ }^{3}$ Ibíd., 1:237.

${ }^{4}$ White, Hechos de los apóstoles, 132.
} 
engañado y vencido por el enemigo". ${ }^{1}$ Concluye que Dios "no dará a uno de sus siervos una experiencia independiente de la iglesia y contraria a la experiencia de ella".

Comentando la conversión de Pablo, White indica por qué la libertad individual debe sujetarse a la iglesia: "El Salvador colocó al inquisidor judio en relación con su iglesia, para que conociera allí la voluntad de Dios concerniente a él". ${ }^{3}$

White señala: "Aunque tenemos una obra individual y una responsabilidad individual delante de Dios no hemos de seguir nuestro juicio independiente, sin considerar las opiniones y los sentimientos de nuestros hermanos, este proceder conducirá al desorden en la iglesia". 4

Elena de White aconseja a quienes "aseveran creer la verdad" que acudan "a quienes tienen experiencia y a la Palabra de Dios con un espíritu humilde y susceptible de ser enseñado", a fin de examinar "sus teorías a la luz de la verdad" con la ayuda de los hermanos que han sido diligentes estudiantes de la Biblia. Al mismo tiempo, deben preguntar a Dios en oración: “¿Es éste el camino del Señor o es una senda falsa en la cual Satanás quiere guiarme?" Asegura: "Recibirán luz y escaparán de la red del cazador".

Según White, "Dios ha investido a su iglesia con especial autoridad y poder, que nadie tiene derecho a desatender y despreciar; porque el que lo hace desprecia la voz de

\footnotetext{
'Ibíd., 1:133.

${ }^{2}$ Ibíd., 1:132.

${ }^{3}$ White, Hechos de los apóstoles, 98.

${ }^{4}$ White, Testimonios para los ministros, 30 .

${ }^{5}$ Ibíd., 54.
} 
Dios". ${ }^{1}$ Con esta misma convicción le fue posible a Pablo escuchar a Ananías y recibir de Dios, a través de él, la devolución de la vista. White exhorta: "No debemos salir de las filas para comenzar a trabajar por nuestra propia cuenta". "Aunque tenemos una obra individual delante de Dios no hemos de seguir nuestro propio juicio independiente". 3

Siendo que el llamamiento de Dios está antes de toda acción y aun de la fe del individuo, el individuo no está nunca solo, sino dentro de la comunidad de creyentes a la que él está incorporado. (Hch. 2:47). El origen de la iglesia no es el individuo sino Dios. Según White, “Aunque es cierto que el Señor guia a los individuos, también es verdad que el Señor está guiando a su pueblo no a unos pocos individuos aislados por aquí y por allá, que creen una cosa u otra". 4

Elena de White dice: "Algunos han adelantado la idea de que, a medida que nos acerquemos al fin del tiempo, cada hijo de Dios actuará independientemente de toda organización religiosa". Inmediatamente manifiesta: "Pero he sido instruida por el Señor en el sentido de que en esta obra no existe tal cosa como que cada hombre puede ser independiente". 5 Por consiguiente presenta las orientaciones recibidas por el Señor: "Se me ha instruido en el sentido de que Satanás realiza esfuerzos especiales para inducir a los hombres a creer que Dios se agrada cuando ellos escogen su propio camino

\footnotetext{
'White, Hechos de los apóstoles, 133.

${ }^{2}$ White, Mensajes selectos, 2:81.

${ }^{3}$ White, Testimonios para los ministros, 30 .

${ }^{4}$ Ibíd., 488.

${ }^{5}$ Ibíd., 489.
} 
independientemente del consejo de sus hermanos". White hace notar que lo que mueve el espíritu de "estas almas tan celosas" es que "consideran una virtud jactarse de su libertad para pensar y actuar en forma independiente". Concretamente advierte: "Se me mostró que es la obra especial de Satanás inducir a los hombres a sentir que Dios les ha ordenado hacer las cosas por su cuenta y escoger su propia forma de obrar independientemente de sus hermanos". ${ }^{2}$ Este estado de cosas será zarandeado. White advierte: "Dios despertará a sus hijos; si otros medios fracasan, se levantarán herejías entre ellos, que los zarandearán, separando el tamo de trigo". 3

\section{Herejía}

En la carta a los Gálatas, Pablo incluye las herejías entre obras de la carne (Gá. $5: 19,20)$. En su segunda carta, el apóstol Pedro presenta la herejía como un poder destructor. "Pero hubo también falsos profetas entre el pueblo, como habrá entre vosotros falsos maestros, que introducirán encubiertamente herejías destructoras y aun negarán al Señor que los rescató, atrayendo sobre sí mismos destrucción repentina. Y muchos seguirán sus disoluciones, por causa de los cuales el camino de la verdad será blasfemado" (2 P. 2:1-2).

¿Se nutre la herejía meramente del error? Si así fuera, no tendría ningún efecto, ni permanecería mucho tiempo. La herejía se alimenta también de la verdad, y de mucha verdad. Por ello parece inextinguible. Con esta mezcla de verdad y error logra confundir y seducir. Elena de White afirma que "el sendero de la verdad se halla al lado y cerca del

\footnotetext{
${ }^{1}$ Ibíd.

${ }^{2}$ Ibid., 29.

${ }^{3}$ White, Joyas de los testimonios, 312.
} 
sendero del error, y ambas sendas pueden parecer ser una para las mentes que no son guiadas por el Espíritu Santo y que, por tanto, no están prontas para discernir la diferencia entre la verdad y el error".

La primera herejía surgió en el cielo. Según White, "las argucias de Lucifer confundieron a muchos ángeles". "Fomentaba secretamente el desacuerdo y la rebelión, con pericia consumada". ${ }^{2}$ La segunda vez que se presentó la herejía fue en el Edén. Satanás sedujo a Eva con una mezcla de lo malo y lo bueno. Escribe White: “Al mezclarse el mal con el bien, su mente se tornó confusa, y se entorpecieron sus facultades mentales y espirituales". ${ }^{3}$

Hablando de la herejía de Kellogg, White explica: "El enemigo de las almas ha procurado introducir la suposición de que había de realizarse una gran reforma entre los adventistas del séptimo día". La suposición de Satanás de que había realizarse una reforma en a la iglesia a través de Kellogg consistía en "renunciar a las doctrinas" y "comenzar un proceso de reorganización". Pregunta White: "Si se efectuara esta reforma, ¿qué resultaría?” Responde: “Los principios de verdad que Dios en su sabiduría ha dado a la iglesia remanente serían descartados. Sería cambiada nuestra religión”. Por esto concluye: "Tenemos una verdad que no admite transigencia. ¿No repudiaremos todo lo que no esté en armonía con esa verdad? ${ }^{4}$

A raiz de la crisis creada por Kellogg, Dios le dio a Elena de White la visión de

${ }^{1}$ Ibíd., 236.

${ }^{2}$ White, Patriarcas y profetas, 17.

${ }^{3}$ Elena G. de White, La educación (Montain Vies, CA: Publicaciones Interamericanas, 1996), 22 .

${ }^{4}$ White, Mensajes selectos, 1:238-239. 
un barco que navegaba envuelto en una "densa neblina". De repente se vio frente a un gigantesco témpano, y el vigía exclamó: “iIceberg a la vista!" Inmediatamente se oyó una voz de autoridad que ordenaba: “¡Hazle frente!” White entendió en esta visión que debía enfrentar a Kellogg: "Sabía cuál era mi deber y que no había un momento que perder. Había llegado el tiempo de una acción decidida. Sin demora, debía obedecer la orden: 'Hazle frente"'.

Referente a los falsos maestros en la iglesia, White señala que "es necesario hacerles frente y oponérseles, no porque sean hombres malos, sino porque enseñan errores y procuran poner sobre la mentira el sello de la verdad".2

El Nuevo Testamento indica que los líderes de la iglesia no optaron por una actitud neutral ni negligente ante la herejía, sino que la discernieron y la enfrentaron. Vieron en la herejía "otro evangelio" (Gá. 1:6-9), que ponía en tela de juicio la fe de la iglesia.

Según Pablo, la herejía se caracterizaba por predicar a un Jesús que no era el Jesús que la iglesia había conocido. Además manifestaba un espíritu que no era el espíritu que la iglesia había recibido, o presentaba un evangelio que no era el que la iglesia había creído (2 Co. 11:4; Gá. 1:9). Ya la iglesia primitiva conocía la desfraternización de los individuos (Mt. 16:15-18; 1 Co. 5:1-5; Tit 3:10-11), no sólo por razón de faltas morales, sino también por adhesión a doctrinas falsas.

En armonía con el Nuevo Testamento, Elena de White aconseja: "No se debe retener en la iglesia a los que insisten en no escuchar las admoniciones y advertencias dadas por los fieles mensajeros de Dios. Deben ser eliminados de la feligresía, porque

\footnotetext{
${ }^{1}$ Ibíd., 1:240.

${ }^{2}$ White, Testimonios para los ministros, 55.
} 
serán como Acán en el campamento de Israel; engañados y engañadores". ${ }^{1}$ Estas actitudes pugnan contra la unidad de la iglesia.

\section{Unidad de la iglesia}

En su oración intercesora, Jesús pidió al Padre por los que ya creían y por los que habían de creer, "que todos fueran uno" (Jn. 17:20-23). La unidad por la cual oró Crisṭo proviene de un solo acto de salvación (1 Co. 15:3-1; Jn. 2:2), un solo mensaje (Mt. 28:20; Mr. 16:15), que debe resultar en una sola comunión de discípulos y servidores de Cristo. Él eliminó la enemistad del hombre con Dios (Ro. 5:10) y también la enemistad de los hombres entre sí (1 Co. 1:12, 13, 31). Cristo es la fuente de unidad de la iglesia (Ro. $12: 5 ; 1$ Co. $12: 18,27)$.

Pablo amonesta a los corintios en contra de formar bandos en la congregación y los exhorta a la unidad sobre el único fundamento que es Cristo (1 Co. 1:10-30). Hace resaltar la unidad del Espíritu en la diversidad de los dones en un cuerpo formado por muchos miembros (1 Co. 12). Presenta que todos, sin distinción de raza, de posición social o de sexo, son uno en Cristo (Gá. 3:27), y declara que los muchos miembros son un solo cuerpo en Cristo (Ro. 12:2-8). Por su parte, Lucas menciona que el gran número de creyentes era de un solo corazón y una misma alma (Hch. 4:42).

Juan registra las palabras de Jesús acerca de un solo pastor y un solo rebaño, y el anhelo de Jesús de que todos los que creyesen en él fuesen una sola cosa como el Padre y el Hijo (Jn. 10:16; 17:20-26). El apóstol Pablo en su carta a los Efesios, en el capitulo 4:1-6 resume el pensamiento cristiano primitivo acerca de la unidad de la iglesia.

${ }^{1}$ Elena G. de White, “Algunos no deben ser retenidos" CBA, 5:1071-1072. 
La unidad de la iglesia es de índole espiritual. Está fundamentada en la unidad de Dios mismo que actúa por Jesucristo en el Espíritu Santo (2 Co. 13:14).

La unidad de la iglesia es también de índole colectiva, pero no es uniformidad. De por sí, la Biblia es un ejemplo de unidad en la diversidad. White explica: "El Señor dio su Palabra ... dio mediante diferentes autores, cada uno con su propia individualidad, aunque trataron el mismo tema". El "Creador de todas las ideas puede impresionar a diferentes mentes con el mismo pensamiento, pero cada una puede expresarlo de manera diferente, y sin embargo sin contradicción". Uniformidad en la expresión "habría sido una pérdida de gracia y belleza particular".'

De igual manera, la iglesia en su diversidad expresa ese solo pensamiento que le ha revelado el Señor, en la forma particular de cada miembro sin que esto sea una contradicción. Las verdades que Dios ha depositado en la iglesia dan coherencia y unidad, no la forma particular de expresión que cada miembro le da. Según White, "el hecho de que existan esas diferencias no debe dejarnos perplejos y confundidos. Es muy raro que dos personas vean y expresen la verdad de la misma manera".

La unidad y coherencia de la iglesia tienen su base en la verdad que profesa. Por ello White declara: "Cristo demanda unidad pero no demanda que nos unamos en prácticas erróneas. El Dios del cielo traza un nítido contraste entre las puras y elevadoras verdades y las falsas doctrinas que descarrian".3

\footnotetext{
${ }^{1}$ White, Mensajes selectos, 1:25.

${ }^{2}$ Ibíd.

${ }^{3}$ White, Mensajes selectos, 1:206.
} 
La unidad en la diversidad plantea un problema para los que insisten en la purificación de la iglesia para de esa manera hacerla una y santa, donde sólo se observe lo que queremos ver. La iglesia está constituida por santos y pecadores.

\section{Santos y pecadores en la iglesia}

Quienes se han dado a la tarea de señalar los defectos de la iglesia, no en forma constructiva, se encuentran con un problema sin solución. No existe perfección absoluta en la iglesia. Desde este punto de partida hay que arrancar sin perder de vista el ideal. Juan, en su primera carta, afirmó: "Si decimos que no tenemos pecado, nos engañamos a nosotros mismos y la verdad no está en nosotros" (1 Jn. 1:8). Por naturaleza, la raza humana es pecadora (Sal. 51:5; 58:3; Jr. 13:23; Ro. 5:12; 3:10). No es nada nuevo ni extraño evidenciar ahora que, por más pueblo de Dios que sea, está conformado por seres humanos débiles, contaminados por el pecado.

Sin embargo, no todo lo que se observa a primera vista, de por sí es pecado. Santiago escribió: "Al que sabe hacer lo bueno, y no lo hace, le es pecado" (Stg. 4:17). Los registros sagrados sobre las debilidades y pecados de los hijos de Dios tienen el propósito de enseñar, consolar, fortalecer la fe y la esperanza de las generaciones sucesivas (Ro. 15:4; 1 Co. 10:11-12). Elena de White, hablando de los personajes bíblicos, señala: “Si se los hubiera presentado como personas intachables, nosotros, con nuestra naturaleza pecaminosa, podríamos desesperar por nuestros errores y fracasos. . . . Así como ellos, aunque vencidos algunas veces, superaron lo perdido y fueron bendecidos por Dios, también nosotros podemos ser vencedores mediante el poder de Jesús". ${ }^{1}$ Sólo Jesús purifica la iglesia.

\footnotetext{
${ }^{1}$ White, Patriarcas y profetas, 243.
} 
¿Se podrían cumplir las expectativas de purificar la iglesia del pecado y los pecadores, a fin de que sólo queden los impecables? Santiago contesta: "Porque todos ofendemos muchas veces" (Stg. 3:2). White observa que "algunas personas parecen pensar que al entrar a la iglesia serán cumplidas sus expectativas y hallarán solamente personas puras". ' Pero también parece notar que "ha habido y habrá personas llenas de celo no conforme a ciencia, que querrán purificar la iglesia y arrancar la cizaña en medio del trigo". ${ }^{2}$ La distinción entre santos y pecadores no es de competencia humana. White señala que "aquellos a quienes el cielo reconoce como santos son los últimos en alardear de su bondad". Y añade: 'Ninguno de los apóstoles o profetas pretendió jamás estar sin pecado". 3

Pablo escribe acerca de su lucha espiritual. Hay un querer y un hacer en conflicto (Ro. 7:14-23). White explica: "En todo corazón existe no sólo poder intelectual, sino también espiritual, una facultad de discernir lo justo, un deseo de hacer lo bueno". Y aclara: "Pero contra estos principios lucha un poder antagónico. ... En la vida de todo hombre se manifiesta el resultado de haber comido del árbol del conocimiento del bien y del mal. ... Hay en su naturaleza una inclinación hacia el mal". ${ }^{4}$ El cristiano, por el hecho de ser creyente, no está libre de su naturaleza pecaminosa; por eso puede cometer pecado (1 Jn. 2:1).

\footnotetext{
${ }^{1}$ White, Testimonios para los ministros, 47.

${ }^{2}$ Ibíd., 46.

${ }^{3}$ White, Palabras de vida del gran maestro, 124.

${ }^{4}$ White, La educación, 26.
} 
En la parábola de Cristo sobre el trigo y la cizaña, los siervos preguntan: “¿Quieres pues que vayamos y la arranquemos?” El dueño de la siembra contestó: “No, no sea que al arrancar la cizaña, arranquéis también con ella el trigo" (Mt. 13:28-29). De ahí que Elena de White comente: "Si tratásemos de extirpar de la iglesia a aquellos que suponemos cristianos falsos, cometeríamos seguramente errores. A menudo consideramos sin esperanza a los mismos a quienes Cristo está atrayendo hacía sî".

Desde el punto de partida de la mezcla de trigo y cizaña en la iglesia se establece que la santidad de la comunidad de creyentes no tiene su fundamento en sus miembros, en su comportamiento moral. Tanto la justificación como también la santificación son obra de Dios. Él es quien ha "escogido desde el principio para salvación, mediante la santificación por el Espíritu" (2 Ts. 2:13; ver también Ef. 1:4). El mismo "Dios de paz os santifique por completo; y todo vuestro ser, espíritu, alma y cuerpo, sea guardado irreprensible para la venida de nuestro Señor Jesucristo" (1 Ts. 5:23).

La santificación de la iglesia es el resultado de la obra de Dios en Cristo. Según Pablo, "mas por él estáis vosotros en Cristo Jesús, el cual nos ha sido hecho por Dios sabiduría, justificación, santificación y redención" (1 Co. 1:30). También escribió, "ya habéis sido santificados ... en el nombre del Señor Jesús y el Espíritu de nuestro Dios" (1 Co. 6:11). White asevera que "la santificación es una obra progresiva".2 La sabiduría de Dios, la justificación, la santificación, y la redención sólo pueden expresarse en una iglesia visible, organizada.

${ }^{1}$ White, Palabras de vida del gran maestro, 50.

${ }^{2}$ Elena G. de White, Mensajes para los jóvenes (Mountain View, CA: Publicaciones Interamericanas, 1967), 113. 


\section{Organización de la iglesia}

El grupo Koinonia considera la estructura organizacional de la Iglesia Adventista como una maquinaria sin el Espíritu y un obstáculo para la realización de la obra de Dios.

Para los adventistas, la organización de la iglesia es un asunto de principio que ha sido puesto en práctica en el curso de la historia del pueblo de Dios. Elena de White comenta que "en los días de la teocracia, cuando Moisés estaba empeñado en llevar solo las cargas tan gravosas, ... Jetro le aconsejó que planeara una sabia distribución de responsabilidades". ${ }^{1}$ Desde el mismo momento en que comenzó la marcha del pueblo de Dios, surgió la necesidad de una estructura, de una organización. Dicha estructura estuvo regida por los "principios de piedad y justicia". Según White, "los mismos principios de piedad y justicia . . . habían de seguir también a aquellos a quienes se les encomendó la vigilancia de la recién organizada iglesia de Dios en la dispensación evangélica". ${ }^{2}$ Los principios y la noción de organización del pueblo de Dios fueron bosquejados ya en el Antiguo Testamento. No es asunto de invención humana. White explica que en "la obra de poner en orden las cosas en todas las iglesias, y de consagrar hombres capaces para actuar como oficiales, los apóstoles mantenían las aitas normas de dirección bosquejadas en los escritos del Antiguo Testamento". 3

\footnotetext{
${ }^{1}$ White, Hechos de los apóstoles, 76.

${ }^{2}$ Ibíd., 78.

${ }^{3}$ Ibíd.
} 
El Espíritu Santo legitima la organización

Referente al concilio de Jerusalén (Hch. 15), Elena de White observa: "Cuando se suscitaban disensiones en alguna iglesia local, ... no se consentía en que la cuestión dividiese la iglesia, sino que se sometía a un concilio de todos los fieles, constituido por los delegados de diversas iglesias locales con los apóstoles y ancianos en función de gran responsabilidad". Así, "por la concertada acción de todos se desbarataban los esfuerzos que Satanás hacía para atacar las iglesias aisladas, y quedaban deshechos los planes de quebranto y destrucción que forjaba el enemigo". ${ }^{1}$

Según White, "la organización de la iglesia de Jerusalén debía servir de modelo para las iglesias que se establecieran en muchos puntos donde los mensajeros de la verdad trabajasen para ganar conversos al evangelio". ${ }^{2}$ Y agrega: "Más adelante en la historia de la iglesia primitiva, una vez constituidos en iglesias muchos grupos de creyentes en diversas partes del mundo, se perfeccionó aún más la organización a fin de mantener el orden y la acción concertada". ${ }^{3}$

En el contexto de la Iglesia Adventista en sus días, escribió: "Sin alguna forma de organización habría gran confusión y la obra no se realizaría con éxito". Señala de manera enfática que "la organización era indispensable para proporcionar sostén al

\footnotetext{
${ }^{1}$ Ibíd., 79.

²Ibid., 75.

${ }^{3}$ Ibid.

${ }^{4}$ White, Testimonios para los ministros, 26.
} 
inisterio, para dirigir la obra en nuevos territorios". ${ }^{1}$ White amonesta: "Que nadie albergue el pensamiento de que podemos prescindir de la organización". Y añade: "En el nombre del Señor os declaro que la organización debe permanecer fortalecida, establecida y fijada". ${ }^{2}$ Esta organización debe permanecer fortalecida como cuerpo de creyentes (Mr. 1:15), "real sacerdocio" (1P. 2:9).

\section{Sacerdocio de todos los creyentes}

El grupo Koinonía critica y cuestiona al ministerio ordenado. Destaca la importancia del sacerdocio de todos los creyentes, y afirma que aceptar algún puesto de liderazgo en la estructura de la organización de la iglesia es signo de apostasía.

Elena de White afirma: "Con el llamamiento de Juan, Andrés, Simón, Felipe y Natanael, empezó la fundación de la iglesia cristiana". ${ }^{3}$ Los apóstoles se convirtieron en los primeros seguidores de Cristo, recibieron responsabilidades de liderazgo, y fueron considerados como parte del fundamento de la iglesia (Ef. 2:20).

Los apóstoles mismos aceptaron el concepto de sacerdocio de todos los creyentes. El apóstol Pedro escribió: "Mas vosotros sois ... real sacerdocio" (1 P. 2:9). Toda la iglesia es sacerdocio y también pueblo de Dios (v. 10).

En la carta a los Efesios el apóstol Pablo señala que Cristo "dio dones a los hombres" (Ef. 4:8). De este modo "constituyó a unos, apóstoles; a otros, profetas; a otros, evangelistas; a otros, pastores y maestros" (v. 11). Esta lista parcial parece presentar los dones como exclusivos del liderazgo de la iglesia. Pero en la primera carta

'Ibíd.

${ }^{2}$ Ibíd., 28.

${ }^{3}$ White, El Deseado de todas las gentes, 144. 
a los Corintios se dirige en forma general a los miembros de la iglesia diciendo: "No quiero hermanos que ignoréis acerca de los dones espirituales" (1 Co. 12:1). Les enfatiza que "a cada uno le es dada la manifestación del Espíritu para provecho" (v. 7). Luego les describe los variados dones que son repartidos entre los miembros del cuerpo de Cristo (vv. 8-12). Los apóstoles representaron de una manera clara que los dones eran otorgados tanto a los que estaban en funciones de autoridad y responsabilidad como a los miembros de la iglesia en general. Pablo afirma que los dones han sido otorgados por el "Espíritu, repartiendo a cada uno en particular como él quiere" (v. 11).

Los apóstoles tomaron también las precauciones para elegir a los líderes de la iglesia (Hch. 6:1-6). Pero al mismo tiempo instruyeron a otros que también habían sido colocados en puestos de responsabilidad para que ejercieran el mismo cuidado cuando ellos eligieran a los dirigentes locales (ancianos, obispos, diáconos; 1 Ti. 3:1-13; Tit. 1:59; 1 P. 5:1-3).

No hay en el Nuevo Testamento ningún indicio que muestre que el sacerdocio de todos los creyentes se oponía a la organización de la iglesia. Elena de White reconoce tanto la necesidad de una iglesia bien organizada como de un ministerio ordenado.

\section{Ministerio ordenado}

Elena de White declara: "Dios tiene una iglesia, y ésta tiene un ministerio designado divinamente. Y él mismo constituyó a unos apóstoles; a otros evangelistas; y a otros, pastores y maestros".

\footnotetext{
${ }^{1}$ White, Testimonios para los ministros, 52.
} 
Un rito especial fue usado en el período apostólico para investir a alguien con autoridad de la iglesia para cumplir una función de servicio. Dice el relato bíblico: "Había entonces en la iglesia que estaba en Antioquía, profetas y maestros: Bernabé, Simón el que se llamaba Níger, Lucio de Cirene, Manaén el que se había criado junto con Herodes el tetrarca, y Saulo. Ministrando éstos al Señor, y ayunando, dijo el Espíritu Santo: Apartadme a Bernabé, y a Saulo para la obra a que los he llamado. Entonces, habiendo ayunado y orado, les impusieron las manos y los despidieron" (Hch. 13:1-3).

Elena de White explica lo que implicaba este rito para Pablo y Bernabé: “Así fueron autorizados por la iglesia, no solamente para enseñar la verdad, sino para cumplir el rito del bautismo y para organizar iglesias, siendo investidos con plena autoridad eclesiástica". White agrega: "Su ordenación fue un reconocimiento público de su elección divina para llevar a los gentiles las alegres nuevas del evangelio". ${ }^{1}$ Pero aclara: "La ceremonia de la imposición de manos no añadía ninguna gracia o cualidad virtual". Dios había hecho el llamado, pero la iglesia, por asuntos del orden y organización, debía poner su sello de aprobación. Mediante esa ceremonia, White afirma, "se colocaba el sello de la iglesia sobre la obra de Dios". ${ }^{2}$ Por lo tanto White señala que "con la separación de Pablo y Bernabé por el Espíritu Santo para una clase definida de servicio, muestra claramente que el Señor obra por medio de agentes señalados en su iglesia organizada". ${ }^{3}$

En la iglesia primitiva se pusieron muy en claro los peligros a que se expone la

'Elena G. de White, Obreros evangélicos, ed. revisada y ampliada (Mountain View, CA: Publicaciones Interamericanas, 1971), 456.

${ }^{2}$ Ibíd.

${ }^{3}$ Ibíd., 458. 
comunidad de creyentes cuando se exageran algunos dones espirituales. Una situación tal fue la que demandó la enérgica intervención de Pablo en la iglesia de Corinto (1 Co. 12-15). Elena de White explica que "en el tiempo de los apóstoles había algunas mal inspiradas almas que pretendían creer en Cristo, pero rehusaban manifestar respeto a sus embajadores". White hace notar que estas personas "declaraban que no seguían a ningún maestro humano sino que eran enseñados directamente por Cristo, sin la ayuda de los ministros del evangelio". ${ }^{2}$ White advierte: "Las impresiones solas no son una guia segura del deber. A menudo el enemigo induce a los hombres a creer que es Dios quien los guía, cuando en realidad están siguiendo sólo al impulso humano". ${ }^{3}$ Según White, este tiempo es un tiempo peligroso igual que en los tiempos apostólicos.

Por lo tanto, hay que "tomar medidas tan especiales, como las que ellos tomaban para asegurar la paz y la armonía". Aconseja: que "los hermanos de experiencia y de sano criterio deben reunirse, y siguiendo la Palabra de Dios y la sanción del Espíritu Santo, debieran con ferviente oración, imponer las manos sobre aquellos que dieron pruebas claras de que recibieron su mandato de Dios y ponerlos aparte para que se dediquen por completo a la obra". ${ }^{4}$ Este ministerio ordenado dispone de la provisión divina del diezmo para su sostén (Nm. 18:23-24; 1 Co. 9:13-14).

\footnotetext{
'White, Los hechos de los apóstoles, 225.

${ }^{2}$ Ibíd.

${ }^{3}$ Ibíd., 226.

${ }^{4}$ Elena G. de White, Primeros escritos (Mountain View, CA: Publicaciones
} Interamericanas, 1955), 101. 


\section{El uso del diezmo}

El vocablo "diezmo" 1 se usa varias veces en las Sagradas Escrituras . De igual manera, el término diezmar también está registrado en varios textos. ${ }^{2}$

"El sistema del diezmo se remonta hasta más allá del tiempo de Moisés. Ya en los días de Adán, se requería ... donativos de índole religiosa. ... Esto continuó durante las generaciones sucesivas y fue practicado por Abraham, quien dio diezmos a Melquisedec, sacerdote del Altísimo". ${ }^{3}$ El hecho que Abraham entregase los diezmos al sacerdote, sugiere que la acción de diezmar tenía un sentido religioso.

Adán y Eva podían disponer de todos los productos del huerto (Gn. 2:8-9, 15-16), menos del árbol del conocimiento del bien y del mal (Gn. 2:17). Elena de White afirma que el árbol que Dios se reservó "constituía la prueba de gratitud y lealtad a Dios". ${ }^{4} \mathrm{De}$ igual manera, después del pecado, "Dios se reservó para sí -dice White- una porción específica ... de los recursos pecuniarios del hombre". Y comentando a Lv. 27:30, 32 dice: “'Toda las décimas ... de Jehová son'. En este pasaje se halla la misma forma de expresarse que en la ley del sábado. 'el séptimo día será [sábado] para Jehová tu Dios (Ex. 20:10)"". Luego escribe: "El sistema del diezmo se funda en un principio tan

${ }^{1}$ C. P. Denyer, Concordancia de las Sagradas Escrituras (San José, Costa Rica: Caribe, 1969), ver "diezmo".

${ }^{2}$ Denyer, ver "diezmar" (Dt. 14:22; 26:12; 1 S. 8:15, 17; Mt. 23:23; Lc. 11:42).

${ }^{3}$ Elena G. de White, Consejos sobre mayordomía cristiana (Mountain View, CA: Publicaciones Interamericanas, 1970), 74.

${ }^{4}$ Ibíd., 69.

${ }^{5}$ White, Patriarcas y profetas, 565. 
duradero como la ley de Dios". Diezmar tiene un sentido religioso, como la adoración, porque es una acción humana de reconocimiento de Dios como Creador y dador de todas las cosas. En el sueño de Jacob en Betel se especifica que Dios es el que provee las necesidades del hombre. Por lo tanto; diezmar es una acción hecha posible por la provisión divina (Gn. 18:12-16). Elena de White explica: "Cuando el benefactor celestial deje de darnos, sólo entonces se nos podrá disculpar, porque no tendremos nada para compartir". ${ }^{2}$ Y agrega: "A cada instante somos sostenidos por el cuidado de Dios y por su poder". 3

En los días de Abraham, por derecho de nacimiento, el sacerdocio recaía en el hijo mayor". 4 Siglos después, Dios eligió a los levitas para ministrar en el culto del tabernáculo. Y destinó el diezmo para su sostén (Nm. 18:21), pues los levitas no recibieron heredad como las demás tribus (Nm. 18:20, 23-24).

El movimiento Koinonia yerra al considerar que cada miembro puede decidir cómo usar el diezmo. Dios es quien estableció el diezmo y cómo debe ser usado. Elena de White observa: "El mismo lenguaje que se emplea en el mandamiento del diezmo, se usa también con respecto al sábado: 'El séptimo día es reposo para Jehová tu Dios ".. 5 En este caso querría decir que el hombre no podría disponer del diezmo ni del sábado sin incurrir en la transgresión de violar el derecho de propiedad de Dios.

\footnotetext{
${ }^{1}$ Ibíd., 72.

${ }^{2}$ Ibíd., 20.

${ }^{3}$ Ibíd.

${ }^{4}$ White, Patriarcas $y$ profetas, 362 .

${ }^{5}$ White, Consejos sobre mayordomía cristiana, 70.
} 
En el Antiguo Testamento, la retención del diezmo por el pueblo aparece conectada varias veces con periodos de desobediencia a Dios. ${ }^{1}$

En el Nuevo Testamento, la vigencia del diezmo es sugerida en Mt. 23:23; en Lc. 11:42; 18:12, y en He. $7: 2,4,5,6,8,9$. Estos textos muestran que diezmar era una práctica mediante la cual se reconocían el origen divino de las instrucciones en cuanto al diezmo. Según White, "el Nuevo Testamento no promulga de nuevo la ley del diezmo como tampoco la del sábado, porque la validez de ambas se da por establecida y su profundo significado espiritual se considera explicado". ${ }^{2}$ Pablo escribe: “¿No sabéis que los que trabajan en las cosas sagradas, comen del templo, y que los que sirven al altar, del altar participan? Así también ordenó el Señor a los que anuncian el evangelio, que vivan del evangelio" (1 Co. 9:13-14). Haciendo referencia a 1 Co. 9:7-14, White afirma: "El apóstol Pablo se refirió aquí al plan del Señor para sostener a los sacerdotes que ministraban en el templo. Aquellos que eran apartados para este sagrado cargo eran sostenidos por sus hermanos, a quienes ellos ministraban las bendiciones espirituales". Luego añade: "A este plan para el sostén del ministerio se refirió Pablo cuando dijo: 'Así también ordenó el Señor a los que anuncian el evangelio que vivan del evangelio'. Y más tarde, escribiendo a Timoteo, el apóstol dijo: 'Digno es el obrero de su jornal (1 Ti. $5: 18)^{\prime \prime}{ }^{3}$

El grupo Koinonía dispone del uso del diezmo como un mecanismo para controlar la eficiencia del ministerio. Ellos creen poder determinar cuál obrero es digno de recibir

\footnotetext{
${ }^{1}$ Ver. 2 Cr. 31: 4-6, 12; Neh. 13:4-5, 10, 15; Mal. 3:6-12.

${ }^{2}$ White, Consejos sobre mayordomía cristiana, 70.

${ }^{3}$ Ibid., 75-76.
} 
los diezmos. ${ }^{1}$ Elena de White afirma que hay personas en la iglesia que están "en contra del sencillo mandato de Malaquías, de traer todos los diezmos a la tesorería de la casa del Señor, e imaginan que ellos tienen una obra que hacer, a saber, amonestar a quienes Dios ha escogido para hacer progresar su mensaje de verdad". Por lo tanto, la amonestación de White es definida: "Que estos hombres . . . abandonen todas sus opiniones antibíblicas concernientes a la naturaleza, función y el poder de los agentes designados por el Señor".

El 23 de marzo de 1893, Elena de White envió una carta de amonestación "al Hno. S." que "proclamaba" que no debía devolverse "el diezmo". En esa carta le advertía que "al paso que el Señor pronuncia una bendición sobre aquellos que traen su diezmo, pronuncia una maldición sobre aquellos que lo retienen". 3

La práctica de la devolución del diezmo es legítima dentro de la iglesia organizada. No obstante, White señala: "Algunos no han estado satisfechos y han dicho: 'No pagaré más mi diezmo, porque no tengo confianza en la forma como se manejan las cosas en el corazón de la obra"”. Para quienes están haciendo esto, la pregunta es: “¿Pero robaréis a Dios porque pensáis que el manejo no es correcto?" En otras palabras, aquí lo que se está tratando de hacer es corregir un pecado con otro pecado. La alternativa que White propone a quienes están preocupados es: "Presentad vuestras quejas en forma clara y abierta, con el espíritu debido a las personas debidas". Éste es el derecho que le otorga Dios a todo creyente que está interesado en su iglesia. Si observa que hay irregularidades

\footnotetext{
${ }^{1}$ García, entrevista.

${ }^{2}$ White, Testimonios para los ministros, 53 .

${ }^{3}$ Ibíd., 58, 60 .
} 
en la administración, White sugiere, "pedid que las cosas sean ajustadas y puestas en orden; pero no retengáis lo que corresponde a la obra de Dios, demostrando así que sois infieles, porque otros no están obrando correctamente".'

\section{Conclusión ${ }^{2}$}

Hay apostasía en la iglesia pero la iglesia no está en apostasía. La iglesia organizada surgió por iniciativa divina bajo la dirección del Espíritu Santo. El ministerio ordenado y el sacerdocio de todos los creyentes no son excluyentes, sino complementarios.

Los diezmos constituyen el recurso provisto por Dios para el sostén del ministerio. Ningún miembro de la iglesia puede retenerlo justificando su acción en los pecados de algunos dirigentes, sin ponerse al margen de la voluntad de Dios. Su devolución debe hacerse en la tesorería de la iglesia organizada.

\footnotetext{
'White, Consejos sobre mayordomia cristiana, 98-99.

${ }^{2}$ Ver también el apéndice, con citas adicionales de los escritos de Elena G. de White que complementan el contenido de este capítulo.
} 


\section{CAPÍTULO VI}

\section{RESUMEN, CONCLUSIONES Y RECOMENDACIONES}

\section{Resumen}

Históricamente, el mensaje adventista entró al territorio colombiano hacia 1916 y 1917 mediante la obra de los colportores, el ministerio organizado y laicos de sostén propio.

En 1922 se realizó el primer bautismo en Colombia. En 1937 se inició en Medellín la Academia Colombo-Venezolana que después se transformó en lo que hoy se conoce como la Corporación Universitaria Adventista.

En la actualidad, la Iglesia Adventista en Colombia consta de 825 iglesias organizadas, 715 grupos, 188.649 miembros, 160 pastores ordenados, 63 escuelas, 19 colegios, 7 colegios secundario incompletos, una universidad, una Unión, 3 misiones y 3 asociaciones.

El ministerio profético de Elena G. de White ha tenido gran influencia en el desarrollo de la obra adventista en Colombia. Desafortunadamente, sus escritos son mal usados por el grupo Koinonía.

La historia de la Iglesia Adventista en Colombia, que presenta un gran desarrollo hoy, se ve afectada por el grupo Koinonía. Este movimiento, con sus ideas antagónicas, causa ansiedad, confusión y anarquía en varias congregaciones del país. 
El grupo se inició en 1979 liderado por Norberto Restrepo. La estrategia fundamental de sus simpatizantes es permanecer como miembros en el seno de la iglesia con el propósito de producir un reavivamiento y reforma manteniendo su filiación como miembros activos.

Lo contradictorio de Koinonía está en la concepción que: en la iglesia no hay apostasía, sino que la iglesia es una apostasía. La organización es una maquinaria sin el Espíritu, que coarta la libertad. Los ministros son clérigos asalariados y los diezmos pueden ser usados con el fin de preparar a los laicos para un ministerio independiente de sostén propio.

Al dar una ojeada al concepto de iglesia en el vocabulario del Nuevo Testamento, encontramos que Dios es el que llama y convoca en Cristo. Cada persona es llamada, pero no como un individuo independiente; es llamada como miembro de un pueblo, puesto que en el mensaje cristiano se trata esencialmente de la preparación y salvación de un pueblo, de la comunidad a la que el individuo está incorporado. Este pueblo o esta comunidad no es el reino de Dios. Esta iglesia es un instrumento de Dios para promover su reino en pro de la salvación de los hombres.

En definitiva, la iglesia auténtica de Cristo desde la era apostólica es el remanente de cada generación al que Dios ha hecho depositario de la verdad probatoria para sus contemporáneos. Este remanente es el que permanece en medio del cambio de la historia. No es la iglesia idealizada. Es la iglesia militante que cree y es creída a pesar de sus imperfecciones. Ésta iglesia es la real a la que Jesucristo está añadiendo cada día a los que han de ser salvos. Esta es la iglesia real en la que se debe establecer la diferencia entre la apostasía en la iglesia y la apostasía de la iglesia. 
La Iglesia Adventista del Séptimo Día, a pesar de sus imperfecciones, entiende que es el remanente para el tiempo del fin. Con su sistema de organización, su ministerio ordenado y su uso del diezmo, está claramente respaldada por las enseñanzas de la Biblia, los escritos de Elena de White y otros autores.

\section{Conclusiones}

A la iglesia verdadera de Cristo se la identifica, no necesariamente por la calidad del comportamiento de sus miembros, sino por el hecho de ser la depositaria de la verdad revelada que se aplica a la generación de su tiempo. No se la puede acusar de ser apóstata.

Cuando a la iglesia se la condena por la apostasía que hay en ella, no se logra percibir la gracia de Dios que penetra la congregación. Sólo se ve una simple organización humana. Cuando se le idealiza como expresión de la absoluta santidad de Dios, no se advierte la amenaza y tentación a que se expone aun al que está dentro de la iglesia.

La iglesia real, como cuerpo de creyentes que voluntariamente se han ligado entre sí, necesita una forma visible de organización.

El diezmo encierra el principio de la soberanía de Dios. Cualquiera que se arrogue el derecho de disponer del diezmo desafia la soberanía de Dios.

\section{Recomendaciones}

Los pastores con sus congregaciones deben procurar, con la gracia de Dios, establecer en forma definida la armonía entre la profesión de fe y la práctica de la revelación que Dios ha otorgado a la Iglesia Adventista para este tiempo. 
Los pastores en Colombia deben impulsar y estimular un estudio asiduo y profundo de la Biblia y de los escritos de Elena G. de White. La carencia de un respaldo intelectual a nuestras convicciones espirituales ha abierto el camino a la confusión de ideas. Los disidentes son asiduos estudiosos de la Biblia y de los escritos de Elena G. de White.

Es necesario volver a estudiar con cuidado la revelación que Dios le ha concedido a la Iglesia Adventista sobre la reforma pro salud y la vida en el campo, para orientar en una forma sana y equilibrada a las congregaciones bajo cuidado pastoral.

Los pastores necesitamos reflexionar en nuestras fallas que son motivo de crítica, resentimiento y rebeldía para nuestros sinceros y buenos hermanos que en su gran mayoría buscan un reavivamiento y una reforma encabezada por sus líderes.

Hay que cambiar la estrategia del disgusto y la amenaza al confrontar a los hermanos que tienen ideas controversiales. Esto requiere pensar que la mayoría de estas personas son bien intencionadas; que están buscando una respuesta que debe ser honestamente dada; que lo que dicen no es siempre un error; que muchas veces, sus exigencias están cargadas de verdad. El error quizá no está en lo que se dice, sino en la manera como quieren actuar mediante la crítica destructiva, la imposición, la exageración y el extremismo. Aquí es donde entra a jugar un papel importante la intervención sabia del pastor que, con un sentido de restauración, por precepto y por ejemplo, reorienta las voces de los sinceros que buscan algo mejor por caminos equivocados. 
Se recomienda, tanto a los administradores como a los pastores, implementar plenamente dos mandatos de Cristo: evangelizar (Mt. 28:18-20); y pastorear (Jn. 21: 15-17). Hay que hacer conciencia de que evangelizar es iniciar a una persona en los caminos del Señor, y que pastorear significa desarrollar y profundizar al creyente en la revelación del Señor. 


\section{APÉNDICE}

\section{CITAS DE LOS ESCRITOS DE ELENA G. DE WHITE}

El propósito de este apéndice es complementar los capítulos IV y $\mathrm{V}$ de este trabajo de investigación.

\section{Dios guía la iglesia}

"El tiempo presente es sumamente peligroso para el pueblo de Dios. Dios está guiando a un pueblo, y no a un individuo aquí y otro allí. Tiene en el mundo una iglesia que permanece en la verdad; y cuando vemos, no solamente hombres sino también jovencitas que prefieren exclamaciones contra la iglesia, sentimos temor de ellos. Sabemos que Dios no los ha enviado, y sin embargo corren y a todos los que no aceptan sus ideas excéntricas los denuncian como opositores al Espíritu de Dios. Todas estas cosas están de acuerdo con los métodos de Satanás, pero la obra de Dios avanzará a pesar de que de vez en cuando surjan quienes trabajen directamente contra la oración de Cisto". (Mensajes selectos, 2:90)

La iglesia: "Ella es el cuerpo organizado de Cristo en la tierra y es necesario respetar sus ordenanzas". (Joyas de los testimonios, 1:396)

"Dios ha concebido a su iglesia el más alto poder debajo del cielo, es la voz de Dios en su pueblo unido como iglesia lo que ha de ser respetado". (Joyas de los testimonios, 1:397)

"Dios está guiando a un pueblo. Ha elegido un pueblo, una iglesia en el mundo, a quien ha hecho depositario de su ley. Les ha confiado un legado sagrado y una verdad eterna que deben presentarse al mundo. El los reprenderá y los corregirá. El mensaje a los Laodicenses se aplica a los adventistas que han tenido gran luz y no han andado en ella. Los que han hecho profesión, de fe, pero que no se han mantenido el mismo paso de su Guía, son los que serán vomitados de su boca, a menos que se arrepientan. El mensaje que afirma que la Iglesia Adventista del Séptimo Día es Babilonia, y que llama a la gente a salir de ella, no procede de ningún mensajero celestial, ni de ningún instrumento humano inspirado por el espíritu de Dios". (Mensajes selectos, 2:75) 
"Nuevamente digo: "El señor no ha hablado mediante ningún mensajero que llame Babilonia a la iglesia que guarda los mandamientos de Dios. Es verdad que hay cizaña junto al trigo, pero Cristo enviaría a sus ángeles a reunir la cizaña en atados para quemarla, y poner el trigo en el granero". (Mensajes selectos, 2:78).

"Quiero decir en el temor de Dios, que se que el Señor tiene pensamientos de Amor y de misericordia para restaurar y enviar a aquellos que se han apartado. El tiene una obra que debe ser hecha por su iglesia. No debe decirse que sus miembros son Babilonia, sin que son la sal de la tierra y la luz del mundo".(Mensajes selectos, 2:76)

"En el mundo existe solamente una iglesia que esté actualmente en la brecha, repasando el muro, reedificando las ruinas; y cualquier hombre que llame la atención del mundo y de las otras iglesias a esta iglesia, denunciándola como Babilonia, hace unạ obra en armonía con la del acusador de los hermanos. ¿Es posible que se levanten entre nosotros hombres que hablen cosas perversas, que expresen los mismos sentimientos que Satanás quisiera ver diseminado en el mundo acerca de los que guardan los mandamientos de Dios y tienen la fe de Jesús? ¿No hay bastante trabajo que hacer para satisfacer vuestro celo en la obra de presentar la verdad a aquellos que están en las tinieblas del error?". (Joyas de los testimonios, 2:356)

"Dios tiene un pueblo en el cual todo el cielo está interesado y dicho pueblo es el único objeto de esta tierra que sea preciso para el corazón de Dios. Que todos los que leen estas palabras les den atenta consideración; porque en el nombre de Jesús yo quisiera grabarlas, en cada alma. Cuando se levanta alguien, de entre nosotros o de afuera, que en el la preocupación de proclamar un mensaje que declara que el pueblo de Dios se cuenta con Babilonia, y asevera que el fuerte pregon es un llamado a salir de ella, podeis saber que no proclama el mensaje de verdad no le recibáis, ni le deseéis éxito; por Dios no habló pro él ni le dio mensaje alguno, sino que el corrió antes de ser enviado". (Joyas de los testimonios, 2:363)

"El Señor ha declarado que la historia pasada se habrá de repetir cuando entremos en la fase final de la obra. Cada verdad que haya dado para estos postreros días debe ser proclamada al mundo. Todo pilar que estableció debe ser fortalecido. No podemos apartarnos ahora del fundamento que Dios asentó". (Joyas de los testimonios, 2:363)

'No es necesario dudar ni temer que la obra no tendrá éxito. Dios está a la cabeza de la obra, y él pondrá todo en orden. Si hay cosas que necesitan ser ajustadas en la dirección de la obra. Dios lo hará y obrará para corregir toda cosa errónea. Tengamos fe en que Dios conducirá el noble barco que lleva al pueblo de Dios sano y salvo al puerto". (Joyas de los testimonios, 2:363)

\section{No hay licencia para oponerse a la iglesia}

"La palabra de Dios no da licencia a ningún hombre para oponer su juicio al de la iglesia, ni le permite insistir en sus opiniones contrarias a las mismas. Si no hubiese 
disciplina ni gobierno en la iglesia, ésta se reduciría a fragmentos no podría mantenerse unida como un cuerpo. Siempre hubo seres humanos de espíritu independiente, que aseveraron que estaban en lo correcto, que Dios los había instruido, impresionado y conducido en forma especial. Cada uno tiene una teoría propia, opiniones que le son peculiares y cada uno sostiene que sus opiniones están de acuerdo con la palabra de Dios. Cada cual sustenta diferente teoría y fe, aunque todos aseguran tener una luz especial de Dios. Apartan a los demás del cuerpo y cada uno es en sí mismo una iglesia separada. Todos no pueden estar en lo cierto, y sin embargo, se declaran conducidos por el Señor". (Joyas de los testimonios, 1:391)

"El Redentor del mundo no sanciona que en asuntos religiosos la experiencia y la acción sean independientes de su iglesia organizada y reconocida donde la tal existe". (Joyas de los testimonios, 1:396)

"Algunos obreros tiran con toda la fuerza que Dios les ha dado, pero no han aprendido todavía que no deben tirar solos. En vez de aislarse tiren en armonía con sus colaboradores. A menos que lo hagan así, su actividad se producirá en el momento inoportuno y en forma errónea. Con frecuencia contrarrestarán aquello que Dios quisiera que se hiciese, y así su trabajo se habrá malgastado". (Joyas de los testimonios, 3:407)

"No es buena señal cuando los hombres se niegan a unirse con sus hermanos y prefieren actuar solos. Que los obreros hagan confidentes suyos a hombres que se sientan libres para señalar toda desviación de los principios correctos. Los que llevan el yugo de Cristo no pueden tirar por separado, sino que obraran con Cristo". (Joyas de los testimonios, 3:406)

"Nuestros ministros deben cesar de sus propias ideas con la actitud de: "Ud debe ver este punto como yo lo veo, o no podrá verse. Fuera con este egotismo". (Mensajes selectos, 1:209)

"Los que han proclamado que la Iglesia Adventista del Séptimo Día es Babilonia, han hecho uso de los Testimonios para dar a su posición apoyo aparente: pero, porque no presentaran lo que durante años ha sido el corazón de mi mensaje: 'la unidad de la iglesia? ¿Por qué no citaron las palabras del ángel: ‘Unios, unios, unios'? ¿Por qué no repitieron la amonestación ni declararon los principios de que 'en la unión hay fuerza, en la división debilidad'?'.. (Joyas de los testimonios, 2:360)

"Durante años he dado mi testimonio en el sentido de que cuando se levantan hombres que aseveran tener gran luz, y sin embargo, abogan por la demolición de lo que el Señor ha estado edificando por medio de sus agentes humanos, están muy engañados y no trabajan en cooperación con Cristo. Los que aseveran que las iglesias adventistas constituyen Babilonia, o parte alguna de Babilonia, deberían permanecer en casa. Deténganse y consideren cuál es el mensaje que debe ser proclamado en este tiempo. En lugar de trabajar con los agentes divinos para preparar un pueblo que pueda subsistir en el día del Señor, se han colocado al lado de aquel que es el acusador de los hermanos, quien los acusa día y noche delante de Dios...". (Joyas de los testimonios, 2:355) 
"Los que se ponen a proclamar un mensaje bajo su propia responsabilidad individual los que, al par que aseveran ser enseñados y conducidos por Dios, se dedican especialmente a derribar lo que Dios ha estado edificando durante años, no están haciendo la voluntad de Dios. Sépase que estos hombres están de parte del engañador. No los creáis. Se están aliando con los enemigos de Dios y la verdad. Se burlarán de la orden del ministerio como de un sistema de sacerdocio. De los tales apartaos: no tengáis comunión con su mensaje, por mucho que citen los Testimonios y traten de atrincherarse detrás de ellos. No los recibáis; porque Dios no les ha encomendado que hagan esta obra. El resultado de una obra tal será la incredulidad en los Testimonios, y en lo posible anularán la obra que ha estado haciendo durante años". (Joyas de los testimonios, 2:357)

"Nadie debe tener confianza en sí mismo, como si Dios le hubiese dado una luz especial más que a sus hermanos. Se nos representa a Cristo como morando en su pueblo; y a los creyentes como edificados sobre del fundamento de los apóstoles y profetas, siendo la principal piedra del ángulo Jesucristo mismo; en la cual, compaginado todo el edificio, va creciendo para ser un templo santo en el Señor: en el cual vosotros también sois juntamente edificados para morada de Dios en Espíritu". (Joyas de los testimonios, 2:103-104)

"Me fueron mostradas muchas personas que pretenderán ser especialmente enseñadas por Dios, y que intentarán guiar a otros, y que debido a un concepto equivocado de lo que es el deber emprenderían una obra que Dios nunca les había encomendado. Como resultado de esto habría confusión". (Mensajes selectos, 2:82)

"No seremos interrumpidos reunión tras reunión por aquellos que pretenden tener un mensaje para presentar. El que se introduce por la fuerza en un lugar donde no es aceptado, no está haciendo la obra de Dios". (Mensajes selectos, vol. 2, 81)

\section{Peligros de la rebelión}

"El objeto de Satanás es deshonrar a Dios, y obra con todo elemento no santificado para lograr este designio. Los hombres a quienes usa como instrumentos para hacer esta obra, son cegados, y no ven lo que están haciendo hasta que están tan profundamente envueltos en la culpabilidad que piensan que ya sería inútil tratar de recobrarse y, arriesgándolo todo, continúan en la trasgresión hasta el amargo fin". (Joyas de los testimonios, 2:107)

"Dudo que una rebelión declarada pueda remediarse. Estudiad en Patriarcas y profetas la rebelón de Coré, Datán y Abirán. Esta rebelión se extendió para incluir a más de dos hombres. Fue conducida por 250 príncipes de la congregación, todos hombres de renombre. Llamad a la rebelión por su nombre debido a la apostasía por el nombre que le corresponde, y considera luego que la experiencia del antiguo pueblo de Dios con todas sus características objetables quedó fielmente registrada en la historia". (Mensajes selectos, vol. 2,453 ) 


\section{Crítica, desconfianza, sospecha y censura}

"Constantemente surgirán situaciones que tenderán a provocar desunión y alejamiento de la verdad. Esta actitud de cuestionar, criticar, denunciar y juzgar a otros, no es una evidencia de que la gracia de Cristo mora en el corazón. No produce unidad". (Mensajes Selectos, 2:90)

"El espíritu de ensalzamiento propio, la inclinación a censurar a nuestros hermanos, desagrada a Dios. Los que se dejan dominar por estos males arrojan dudas sobre la obra de Dios, y dan a los escépticos motivos para disculpar su incredibilidad. Cuanto más importante sea el cargo de uno, y tanto mayor sea su influencia, tanto más necesitará cultivar la paciencia y la humildad". (Patriarcas y profetas, 445)

"Acusar y criticar a los que Dios está empleando es acusar y criticar al Señor que los ha enviado. Todos necesitan cultivar las facultades espirituales a fin de discernir correctamente las cosas religiosas. Algunos no han podido distinguir el oro puro del oropel, la sustancia de la sombra". (Testimonios para los ministros, 466-467)

"Es una cuestión muy seria ir de casa en casa, y bajo la pretensión de llevar a cabo un trabajo misionero, sembrar la semilla de la desconfianza y la sospecha. Cada una germina rápidamente, y así se crea desconfianza en los siervos de Dios que tienen un mensaje para dar al pueblo. Cuando Dios habla mediante sus siervos, la semilla [de desconfianza y sospecha] sembrada, ya ha echado raíces de amargura. La palabra cae entonces en corazones que no quieren oír y en corazones que no quieren responder. Debido a ello, ningún poder terrenal ni ningún poder celestial puede abrirse paso hacia el alma". (Mensajes selectos, 2,80 )

"Los que se alimentan de las hojarascas de los fracasos y deficiencias ajenas, que juntan para sí mismos los miasmas malsanos de las negligencias y defectos de sus vecinos, haciéndose basureros de la iglesia, no constituyen ninguna ventaja para la sociedad de la cual forman parte, sino que son, en realidad, una carga para la comunidad a la que imponen su presencia”. (Joyas de los testimonios, 1:491)

"Pero estos habladores indisciplinados se aferran a los detalles más desagradables de trabajo, como el liquen a las asperezas de la roca. Estas personas se atrofian espiritualmente al espaciarse de continuo en las faltas y los defectos de los demás. Son normalmente incapaces de discernir las acciones buenas y nobles, los esfuerzos abnegados, el verdadero heroísmo y sacrificio propio. No se están volviendo más nobles ni más elevados en su vida y esperanza, ni más generoso y amplios en sus ideas y planes. No cultivan la caridad que debe caracterizar la vida del cristianismo. Están degenerando cada día y sus prejuicios y opiniones se estrechan cada vez más. La mezquindad es su elemento, y la atmósfera que los rodea es venenosa para la paz y la felicidad". (Joyas de los testimonios, 1:394) 
"Muchos de los que hallan placer especial en discurrir y espaciarse en los defectos, reales o imaginarios, de aquellos que llevan pesadas responsabilidades en relación con las instituciones de la causa de Dios. Pasan por alto el bien que han realizado, los beneficios que han producido su ardua labor y su devoción incansable a la causa, y fijan su atención en alguna equivocación aparente, en algún asunto que una vez consumado, ellos imaginan que se podria haber hecho de una manera mejor con resultados más alagüeños, cuando la verdad es que, si ellos hubiesen tenido que hacer la obra, o se habrían negado a dar el paso en las circunstancias desalentadoras del caso, o habrían actuado con más indiscreción que quienes la hicieron siguiendo las indicaciones de la providencia divina". (Joyas de los testimonios, 1:493-494)

"Lo que la iglesia necesita no son cargas sino obreros fervientes; no personas que censuren sino edificadores de Dios. Se necesitan verdaderos misiones en el corazón, hombres que retengan la fortaleza, que sean tan fieles como el acero para preservar el honor de aquellos a quienes Dios ha colocado a la cabeza de su obra, y que harán cuanto puedan para sostener la causa en todos sus departamentos, aún a costa del sacrificio de sus propios intereses y vidas, si es necesario". (Joyas de los testimonios, 1:491)

"No tenemos tiempo para hablar de incredibilidad y para chismear; no tenemos tiempo ahora para realizar la obra del diablo. Que todos tengan cuidado de no desarraigar la fe de otros al sembrar las semillas de envidia, celo, desunión: porque Dios oye las palabras y juzga no mediante aserciones que no valen nada, sino por el fruto que produce la conducta de una persona". (Mensajes selectos, 2:80)

"El tiempo gastado en criticar las intenciones y las acciones de los siervos del Señor sería mejor empleado en la oración. Si los que buscan fallas en los demás conociesen la verdad referente a los mișmos a quienes critican, a menudo tendrían otra opinión acerca de ellos, en vez de criticar y condenar a los otros, sería mejor que cada cual dijese: 'Debo trabajar para mi propia salvación'”. (Joyas de los testimonios, 3:229)

"La envidia, los celos, las sospechas y las maledicencias son de Satanás, y serán eficazmente el camino para que el Espíritu Santo no obre. No hay en este mundo nada que sea tan caro para Dios como su iglesia. No hay nada, que él custodie cuidando más celoso. No hay nada que ofenda tanto a Dios como un acto que perjudique la influencia de aquellos que le sirven. El llamará a cuenta a todos aquellos que ayuden a Satanás en su obra de criticar y desalentar". (Joyas de los testimonios, 2:381)

"Aquellos que han usado el talento del habla para desanimar a los siervos de Dios ocupados en el adelanto de la causa de Dios y en hacer planes para dominar la oposición, deben pedir perdón a Dios por el daño que han hecho a su obra por medio de sus perjuicios malvados y sus palabras poco amables. Mediten en el daño que han hecho divulgando falsos informes y juzgando a aquellos cuyos casos no les toca juzgar". (Joyas de los testimonios, 3:229)

"Los que os habéis educando a vosotros mismos dentro de un Espíritu de crítica y acusación, recordad que estáis imitando el ejemplo de Satanás. Cuando os conviene 
tratáis los testimonios como si creyeráis en ellos citando de ellos para robustecer alguna declaración que queréis que prevalezca. . . . Cuando los testimonios hablan en contra de vuestras ideas, los tratáis muy livianamente". (Mensajes selectos, 2:48)

\section{Los enemigos y los que más daño le causan a la obra de Dios}

"Los peores enemigos que tenemos son aquellos que están tratando de destruir la influencia de los atalayas que están sobre los muros de Sión. Satanás trabaja por medio de agentes. . . . Trabaja de acuerdo con un plan definido, y sus agentes obran de concierto. . . . Su influencia tiende a minar la confianza en la obra del Espíritu de Dios. . . . Tened cuidado, no sea que seáis hallados ayudando al enemigo de Dios y del hombre mediante la difusión de falsos informes, y por crítica y oposición decida". (Joyas de los testimonios, 2:106)

"El mayor daño que pueda recibir el pueblo de Dios proviene de aquellos que salen de él hablando cosas perversas. Por su medio queda vilipendiado el camino de la verdad". (Joyas de los testimonios, 2:103)

"Nunca el error es inofensivo, ni santifica, sino que siempre es peligroso y produce confusión y disención". (Joyas de los testimonios, 2:104)

"El objeto de Satanás es deshonrar a Dios, y obra con todo elemento no santificado para lograr este designio". (Joyas de los testimonios, 2:107)

“ $\mathrm{OH}$, cuan terriblemente mancillada queda la causa de Dios por la perversa voluntad del hombre y su genio insumiso! ¡Cuánto sufrimiento trae él sobre sí el seguir sus propias y temerarias pasiones!"'. (Joyas de los testimonios, 1:476)

\section{No podemos adelantarnos a Dios}

Tengo una advertencia para nuestros hermanos, y es que deben seguir a su guía y no adelantarse a Cristo. No se realice ninguna obra apresurada en estos tiempos. Cuidando en realizar fuertes declaraciones que induzcan a las mentes desequilibradas a pensar que tienen una luz maravillo a procedente de Dios. El que lleva el mensaje al pueblo de Dios deje ejercer un perfecto control siempre debería recordar que la senda de la presunción está muy cerca de la senda de la fe. En ningún caso debería utilizar expresiones extravagantes, porque esto afectará con toda seguridad a una clase determinada y pondrá en juego influencias que no podrán ser mejor controladas que un caballo impetuoso. Permítase por una sola vez que el impulso y la emoción dominen el juicio sereno y se tendrá excéso de velocidad, aún cuando se viaje en un camino correcto. El que viaje con demasiada velocidad descubrirá que ello es peligroso en más de un sentido. Puede ser que no transcurra mucho tiempo antes que se salga del camino correcto y se interne por un sendero equivocado"'. (Mensajes selectos, 2:103-104) 
"En este tiempo, por encima de todo otro tiempo, el juicio apresurado, las opiniones formadas descuidadamente, sin evidencia suficiente, pueden conducir a los resultados mas desastrosos. Cuando buscamos las causas a partir de los efectos, encontramos que en esa forma se ha producido daños que en algunos casos son irrediables. Cuanta sabiduría y discernimiento espiritual se necesitan para proporcionar alimento al rebaño de Dios, que sea forraje puro cabalmente zarandeado. Los rasgos de carácter naturales y hereditarios necesitan ser sometidos a un firme control, porque de lo contrario el celo encendido y los buenos propósitos se desviarán hacia el mal y el exceso de los sentimientos producirá tales presiones en los corazones que estos serán arrebatados por el impulso y permitirán que las impresiones sean su guía". (Mensajes selectos, 2:106)

"Hay que controlar el impulso espiritual para impedir que se pronuncien palabras imprudentes y que se expresen palabras exaltadas que harán que personas impulsivas pierdan su rumbo. Los sentimientos de algunos son prontamente agitados por declaraciones fuertes, y su imaginación agranda la declaración hasta darle enormes dimensiones; todo esto les parece real y se hacen fanáticos. La experiencia espiritual se vuelve afiebrada y enferma". (Mensajes selectos, 2:106)

\section{La autoridad de la iglesia}

"Dios ordenó que los representantes de su iglesia de todas partes de la tierra, cuando están congregados en la Asociación General, tengan autoridad" (Obreros evangélicos, 506)

"Pero cuando, en un congreso de la Asociación General, se manifiesta el criterio de los hermanos de todas partes del campo reunidos, la independencia y el juicio privado no deben mantenerse con terquedad, sino que deben ceder" (Obreros evangélicos, 506)

"A veces, cuando un pequeño grupo de hombres al cual ha sido confiada la dirección general de la obra, ha tratado, en el nombre de la Asociación General, de llevar a cabo planes imprudentes y de restringir la obra de Dios, he dicho que ya no podía considerar la voz de la Asociación General, representada por estos pocos hombres, como la voz de Dios pero esto no quiere decir que las decisiones de una Asociación General compuesta de una asamblea de representantes debidamente nombrados, de todas partes del campo, no deban respetarse" (Obreros evangélicos, 506)

"Demos a la autoridad organizada más elevada de la iglesia lo que propendemos dar a un hombre o a un pequeño grupo de hombres" (Obreros evangélicos, 506) 


\section{Uso de los testimonios}

"Hay quienes toman de la palabra de Dios, y también de los testimonios, párrafos alistados $\mathrm{u}$ oraciones que se pueden interpretar, para adaptarlos a sus ideas, se detienen en ellos y se fundamentan en su posición, cuando Dios no los está guiando". (Mensajes selectos, $1: 210)$.

Hablando de un hombre llamado Gamire le dice al Hno. K: "El pretendía creer en los testimonios. Pretendía aceptar que eran verdaderos, y los utilizaba en la misma manera, que Ud. los ha empleado para proporcionar fuerza y apariencia de verdad a sus pretensiones". (Mensajes selectos, 2:74)

"Satanás está trabajando en muchas formas para que los mismos hombres que debieran predicar el mensaje están ocupados con teorías hábilmente confeccionadas que él hará que parezcan de tal magnitud e importancia como para llenar la mente. Y al paso que piensan que están dando grandes y maravillosos pasos en su vida cristiana, están idolatrando unas pocas ideas y se daña su influencia y tiene poco peso del lado del Señor”. (Mensajes selectos, 1:210)

"Algunos de los que creen en los Testimonios han errado queriendo imponerlos indebidamente a otros". (Joyas de los testimonios, 2:283)

"Algunos de los predicadores están muy atrasados. Profesan creer en los testimonios dados, y algunos hacen mal al erigirlos en regla de hierro para aquellos que no han tenido experiencia con referencia a ellos, pero no los practican ellos mismos". (Joyas de los testimonios, 2:285)

"Algunos cristianos aceptan ciertas porciones de los testimonios como un mensaje de Dios, pero rechazan las que condenan sus costumbres favoritas. Tales personas trabajan para su mengua en la iglesia". (Joyas de los testimonios, 2:355)

"Esta es la forma en que son tratados mis escritos por los que desean entenderlos mal y pervertirlos. Convierten la verdad de Dios en mentira. En la misma forma en que tratan lo escrito en mis artículos publicados en mis libros, así tratan la Biblia los escépticos e incrédulos. La leen de acuerdo con el deseo de pervertir, aplicar mal o voluntariamente distorsionar las declaraciones de su verdadero significado. Afirman que la Biblia puede probar cualquier cosa y todas las cosas, que cada secta demuestra que su doctrina es correcta y que las demás diversas doctrinas se prueban mediante la Biblia". (Mensajes selectos, 1:22)

\section{Cómo saber que poseemos la verdad}

"Hay mil tentaciones disfrazadas y preparadas para aquellos que tienen la luz de la verdad, y la única seguridad para cualquiera de nosotros consiste en no recibir ninguna nueva doctrina, ninguna nueva interpretación de las Escrituras, sin someterla primero a hermanos de experiencia. Presentádsela con un espíritu humilde y dispuesto a recibir 
enseñanza, con ferviente oración, y si ellos no la aceptan, ateneos a su juicio; porque 'en la multitud de consejeros hay salud' (Pr. 11:14)”. (Joyas de los testimonios, 2:105)

"En estos días peligrosos no debemos aceptar todo lo que los hombres nos traen pretendiendo que es verdad. Cuando supuestos maestros de Dios acuden a nosotros y dicen que tienen un mensaje procedente de Dios, es necesario preguntar cuidadosamente: ¿Cómo sabemos que esto es verdad? Jesús nos ha dicho que 'muchos falsos profetas se levantarán, y engañarán a muchos' (Mat. 24:11). Pero no necesitamos ser engañados, porque la palabra de Dios nos proporciona una prueba por la cual podemos conocer su verdad. El profeta dice: 'AA la ley y el testimonio! Si no dijesen conforme a esto, no les ha amanecido' (Isa. 8:20)". (Mensajes selectos, 2:113)

"El espíritu de error nos aleja de la verdad, mientras que el Espíritu de Dios nos conducirá a ella. Pero, decís vosotros una persona puede estar en el error y pensar que posee la verdad. ¿Qué hacer en tal caso? A lo que contestamos: el Espíritu y la Palabra están de acuerdo. Si alguien se juzga a sí mismo por la Palabra de Dios y encuentra armonía perfecta en toda la Palabra, entonces debe creer que posee la verdad; pero si encuentra que el espíritu que le guía no armoniza, con todo el contenido de la ley de Dios o su libro, ande entonces cuidadosamente para no ser apresado en la trampa del diablo". (El conflicto de los siglos, 448)

"El Espíritu que inspiró las Escrituras siempre conduce a las Escrituras". (Mensajes selectos, 2:1, 49) 


\section{BIBLIOGRAFÍA}

Amorocho, César, estudiante del séptimo semestre de Educación Teología en la Corporación Universitaria Adventista con sede en Medellín. Entrevista por el autor, Medellín, 14 de mayo de 2002.

Andrade, Eladio, pastor del distrito de Popayán de la Asociación del Pacífico, con sede en Cali. Entrevista por el autor, Medellín, 14 de mayo de 2002.

Árboles de justicia y el mensaje de 1888. Cali: Koinonía, s. f.

Barclay, William. Palabras griegas del Nuevo Testamento. Traducido por Javier José Marín C. Buenos Aires: Casa Bautista, 1977.

Barrera, Edilso, secretario de la Misión Centro Occidental, con sede en Medellín. Entrevista por el autor, Medellín, 14 de mayo de 2002.

Bauer, Johannes. Diccionario de teología biblica. Traducido por Humberto Casanova R. y Guillermo Serrano. Grand Rapids: Desafio, 1985.

La Biblia comentada. $3^{\text {a }}$ ed. 9 vols. Editada por Alberto Colunga. Madrid: Biblioteca de Autores Cristianos, 1960-1967.

Caballero Yoccou, Raúl. Sobre esta roca edificaré mi iglesia. Miami: Unilit, 1995.

Congar, Yves M. J. Jalones para una teología del laicado. $3^{\mathrm{a}} \mathrm{ed}$. Traducido por Sebastián Fuster. Barcelona: Estela, 1965.

Comentario bíblico adventista. 7 vols. Editado por Francis D. Nichol. Traducido por V. E. Ampuero Matta. Boise: Publicaciones Interamericanas, 1978-1990.

Dana, H. E. Manual de eclesiología. Traducido por Adolfo Robleto y otros. El Paso, TX: Casa Bautista, 1987.

Denyer, C. P. Concordancia de las Sagradas Escrituras. San José, Costa Rica: Caribe, 1969.

Departamento de Educación de la División Interamericana. La orientación profética en el movimiento adventista. Traducido por Cristina Samayoa. Miami: Departamento de Educación, División Interamericana, 1964. 
Departamento de Educación de la Asociación General de la Iglesia Adventista del Séptimo Día. La historia de nuestra iglesia. Buenos Aires: Casa Editora Sudamericana, 1963.

Diccionario biblico adventista del séptimo día. Edición revisada. Editado por Siegfried H. Horn. Buenos Aires: Casa Editora Sudamericana, 1995.

Diccionario biblico ilustrado. Editado por Vila Santamaría. Barcelona: CLIE,1983.

Diccionario conciso griego-español del Nuevo Testamento. Editado por Elsa L. Tames e Irene W. de Foulkes. Londres: Sociedades Bíblicas Unidas, 1978.

Douglass, Herbert E. Mensajera del Señor. Traducido por Tulio N. Peverini. Buenos Aires: Casa Editora Sudamericana, 2000.

Durán, Misael, director del departamento de Ministerio Personal de la Misión del Atlántico con sede en Barranquilla. Entrevista por el autor, Medellín, 3 de mayo de 2002.

Escandón, Tirso. Autobiografia: Apuntes de una familia victoriosa. Riverside, CA: por el autor, 1987.

Evans, William. Las grandes doctrinas de la Biblia. Traducido por M. Garrido Aldama. Chicago: Moody, 1960.

Fiedler, Dave. El adventismo y Walter Martin. Eatonville, WA: Hope International, 1991.

García, John, miembro de la Iglesia Adventista Central de Medellín. Entrevista por el autor, Medellín, 5 de mayo de 2002.

General Conference of Seventh-day Adventists. Annual Statistical Report. Silver Spring, MD: General Conference of SDA, 2000, 2001.

Goldstein, Clifford. Entre el cordero y el león. Bogotá: Asociación Publicadora Interamericana, 1995.

Hernández, Alberto, pastor del distrito Central de Medellín. Entrevista por el autor, Medellín, 30 de abril de 2002.

Hennessey Taylor, Samuel, miembro de la Iglesia Central de Medellín. Entrevista por el autor, Medellin, 11 de abril de 2002.

Hope International. "Fundación Educativa Salud Integral para el Desarrollo Integral del Hombre". Nuestro Firme Fundamento 6 (1989): 32. 
Iglesias Ortega, Enoc. Presencia adventista en Colombia. Medellín: Corporación Universitaria Adventista, 1999.

Issues: The Seventh-day Adventist Church and Certain Private Ministries. Silver Spring, MD: North American Division, 1992.

Jamieson, Roberto, A. R. Fausset y David Brown. Comentario exegético y explicativo de la Biblia. 2 vols. $3^{\mathrm{a}} \mathrm{ed}$. Traducido por Jaime C. Quarles, Lemuel C. Quarles, José M. Rodríguez, Juan B. Garaño y Francisco Macías. Buenos Aires: Casa Bautista, 1967.

Jeremías, Joachim. Teología del Nuevo Testamento. $2^{\mathrm{a}}$ ed. Traducido por Constantino Ruiz Garrido. Salamanca: Sígueme, 1974.

Jiménez, Elías, estudiante de primer semestre de teología en la Corporación Universitaria Adventista. Entrevista por el autor, Medellín, 7 de mayo de 2002.

Jones, Alonzo. Individualidad en religión. Dichendorf, Alemania: Botschaft für unsere Zeit, 1987.

Kittel, Gerhard, y Gerhard Friedrich, eds. Theological Dictionary of the New Testament. 10 vols. Traducido por Geoffrey Bramiley. Grand Rapids: Eerdmans, 1964-1976.

Knight, George R. Conozcamos a Elena de White. Bogotá: Asociación Publicadora Interamericana, 2001.

. Guía del fariseo para una santidad perfecta: Un estudio sobre el pecado y la salvación. Traducido por Silvia González. Bogotá: Asociación Publicadora Interamericana, 1998.

Lacueva, Francisco. Curso de formación teológica evangélica. Vol. 6, La iglesia, cuerpo de Cristo. Barcelona: CLIE, 1973.

Ladd, George Eldon. El apocalipsis de Juan: Un comentario. $3^{\mathrm{a}}$ ed. Traducido por Arnoldo Canclini. México, D.F.: Caribe, 1985.

Leavell, Roland. Mateo: El rey del reino. Traducido por Alfredo de Quezada. El Paso, TX: Casa Bautista, 1988.

Leonard, Bill J. La naturaleza de la iglesia. Traducido por Clark H. Stanley. E1 Paso, TX: Casa Bautista, 1989.

López, Francisco María. Pobreza y riqueza en los evangelios. Madrid: Studium, 1963. 
Maxwell, Mervyn. El destino del planeta en rebelión. $2^{\text {a }}$ ed. Bogotá: Asociación Publicadora Interamericana, 1993.

Navarro, Guillermo, pastor adventista por un tiempo asociado con Koinonía. Entrevista por el autor, Bucaramanga, 23 de abril 2002.

Nocke, Franz Josef. Escatologia. Barcelona: Herder, 1984.

Nuevo Diccionario de la Biblia. Editado por Alfonso Lockward. Bogotá: Unilit, 1999.

Pabón de Urbina, José M. Diccionario manual griego-español. $17^{\mathrm{a}}$ ed. Barcelona: Bibliograf, 1974.

Petter, Hugo M. Concordancia greco-española del Nuevo Testamento. Barcelona: CLIE, 1976.

Priebe, Dennis E. ¿Cómo vivió Cristo?. Cara a cara con el verdadero evangelio. Barquisimeto: Fundación las delicias, s. f.

- La imposibilidad del hombre, la posibilidad de Dios. Cara a cara con el verdadero evangelio. Barquisimeto: Fundación las delicias, s. f.

- ¿Qué es pecado?. Cara a cara con el verdadero evangelio. Barquisimeto: Fundación las delicias, s. f.

Ramos Escobar, Walter, capellán del Sanatorio de Supía, de la Misión Centro Occidental con sede en Medellín. Entrevista por el autor, Medellín, 29 de abril de 2002.

Sabugal, Santos. Christos: Investigación exegética sobre la cristología joannea. Barcelona: Herder, 1972.

Sánchez Mielgo, Gerardo. Evangelios sinópticos. Bogotá: Universidad Santo Tomás, 1983.

Sarmiento, Roberto, miembro de iglesia de la Asociación del Oriente Colombiano. Entrevista por el autor, Bogotá, 27 de abril de 2002.

Schmidt, K. L. "Ekklèsia". Theological Dictionary of the New Testament. 10 Vols. Editado por Gerhard Kittel y Gerhard Friedrich. Traducido por Geoffrey Bromiley. Grand Rapids: Eerdmans, 1964-1976, 3:514.

Schnackenburg, Rudolf. Reino y reinado de Dios. $3^{\mathrm{a}}$ ed. Traducido por José Coscaya Osa. Madrid: Fax, 1974. 
Seventh-day Adventist Encyclopedia. Edición revisada. 2 vols. Editado por Don F. Neufeld. Washington, DC: Review and Herald, 1996.

Sistiva, Alicia de, miembro de la iglesia de Palermo de la Asociación del Alto Magdalena, con sede en Bogotá. Entrevista por el autor, Bogotá, 27 de abril de 2002.

Trenchard, Ernesto. Introducción a los cuatro evangelios. $2^{\mathrm{a}}$ ed. Madrid: Literatura Bíblica, 1981.

Unión Colombiana de los Adventistas del Séptimo Día. "Informe estadístico", 30 de noviembre de 2001.

Vargas, Nelson, secretario de la Asociación del Oriente Colombiano, con sede en Bucaramanga. Entrevista por el autor, Bucaramanga, 23 de abril de 2002.

Vine, W. E. Diccionario expositivo de las palabras del Antiguo y del Nuevo Testamento. Bogotá: Caribe, 1999.

Wade, Loron. El futuro del mundo revelado en el Apocalipsis. Bogotá: Asociación Publicadora Interamericana, 1987.

Wallenkampf, Arnold Valentin. Lo que todo adventista deberia saber sobre 1888. Traducido por Rolando A. Itin. Buenos Aires: Casa Editora Sudamericana, 1989.

[White, Elena G. de.] Salid de las ciudades. Barquisimeto: Fundación Las Delicias, s.f.

White, Elena G. de. "Algunos no deben ser retenidos". Comentario biblico adventista. 7 vols. Editado por Francis D. Nichol. Traducido por V. E. Ampuero Matta. Boise: Publicaciones Interamericanas, 1978-1990. 5:10711072.

. El conflicto de los siglos. Bogotá: Asociación Publicadora Interamericana, 1954.

. Consejos sobre mayordomía cristiana. Mountain View, CA: Publicaciones Interamericanas, 1970.

. El Deseado de todas las gentes. Buenos Aires: Casa Editora Sudamericana, 1976. 1967.

. La educación. Mountain View, CA: Publicaciones Interamericanas, 
White, Elena G. de. Los hechos de los apóstoles. Mountain View, CA: Publicaciones Interamericanas, 1966.

. Joyas de los testimonios. 3 vols. Mountain View, California: Publicaciones Interamericanas, 1953.

. Mensajes para los jóvenes. Mountain View, CA: Publicaciones Interamericanas, 1967.

. Mensajes selectos. 3 vols. Mountain View, CA: Publicaciones Interamericanas, 1966.

. El ministerio de curación. Mountain View, CA: Publicaciones Interamericanas, 1975.

. Notas biográficas de Elena G. de White. Buenos Aires: Casa Editora Sudamericana, 1981.

. Obreros evangélicos. Edición revisada y ampliada. Buenos Aires: Casa Editora Sudamericana, 1971.

. Palabras de vida del gran maestro. Mountain View, CA: Publicaciones Interamericanas, 1971.

. Patriarcas y profetas. Mountain View, CA: Publicaciones Interamericanas, 1955. 1962.

Primeros Escritos. Mountain View, CA: Publicaciones Interamericanas, . Profetas y reyes. Mountain View, CA: Publicaciones Interamericanas, 1957.

. Testimonios para los ministros. Buenos Aires: Casa Editora Sudamericana, 1977.

Zea, Virgilio. Jesús el hijo de Dios. Bogotá: Universidad Santo Tomás, 1989. 


\section{CURRÍCULUM VÍTAE}

Nombre: José Evelio García.

Dirección: $\quad$ Corporación Universitaria Adventista, Carrera 84 \# 33 AA-1, Medellín, Colombia.

Lugar de nacimiento: $\quad$ Roldanillo, Colombia.

Ordenación: $\quad$ Enero de 1982.

Esposa: Consuelo Ramírez Colonia.

Hijos: $\quad$ Juan David, Claudia Lorena, Pablo Andrés.

EDUCACIÓN:

1973 Maestro Normalista, Instituto Colombo-Venezolano.

1976 Licenciatura en Teología, Corporación Universitaria Adventista.

1989 Maestría en Religión, Universidad de Andrews.

2002 Doctorado en Ministerio, Universidad de Andrews.

EXPERIENCIA MINISTERIAL

1975-1978 Preceptor

1979 Rector

1980-1984 Pastor de iglesia

1985-1987 Pastor de iglesia

1987-1991 Vicerector estudiantil

1991-1993

1993-1996

1997

1998- Docente Escuela Teología

Pastor de iglesia

Secretario ministerial,

Pastor de iglesia
Instituto Colombo-Venezolano, Medellín.

Colegio Modelo Adventista, Misión de las Islas Colombianas.

Asociación del Pacífico, Cali.

Corporación Universitaria Adventista, Medellín.

Corporación Universitaria Adventista

Medellín.

Quito, Ecuador.

Departamental Mayordomía

Departamental Evangelismo Misión del Norte, Quito, Ecuador.

Corporación Universitaria Adventista, Medellín.

Corporación Universitaria Adventista, Medellin. 